U.S. DEPARTMENT OF THE INTEFIOR

U.S. GEOLOGICAL SURVEY

\title{
Sand Resource Survey Offshore Sand Key Pinellas County, Florida
}

\author{
by \\ Guy Gelfenbaum, Stanley D. Locker, and Gregg R. Brooks
}

Open-File Report 95-547 


\title{
U.S. DEPARTMENT OF THE INTERIOR
}

\author{
U.S. GEOLOGICAL SURVEY
}

\section{Sand Resource Survey Offshore Sand Key Pinellas County, Florida}

\author{
by \\ Guy Gelfenbaum 1 , Stan D. Locker ${ }^{2}$, and Gregg R. Brooks 3
}

Open-File Report 95-547

This report is preliminary and has not been reviewed for conformity with U.S. Geological Survey editorial standards or with the North American Stratigraphic Code. Any use of trade, product, or firm names is for descriptive purposes only and does not imply endorsement by the U.S. Government.

${ }^{1}$ U. S. Geological Survey, Center for Coastal Geology and Regional Marine Studies, St. Petersburg, FL 2 University of South Florida, Department of Marine Sciences, St. Petersburg, FL

3 Eckerd College, St. Petersburg, FL 


\section{TABLE OF CONTENTS}

\section{INTRODUCTION}

II. METHODS

GEOPHYSICAL SURVEYS

High-Resolution Seismic Survey

Acquisition

Processing

Interpretation

Side-Scan Sonar Survey

VIBRACORE SAMPLING

Field

Laboratory

III. RESULTS

GEOPHYSICAL SURVEYS

Side-Scan Sonar Bottom Type Map

Sediment Thickness Map

VIBRACORE SAMPLING

Core Log Descriptions

Grain Size Analysis

IV. INTERPRETATION

V. ACKNOWLEDGEMENTS

VI. REFERENCES

VII. APPENDICES

A1. SEISMIC SEGMENTS AT CORE SITES

A2. CORE LOGS

A3. GRAIN SIZE GRADATION CURVES

VIII. PLATES

Plate 1. Location Map

Plate 2. Trackline and Vibracore Location Map

Plate 3. Side-Scan Sonar Interpretation Map

Plate 4. Sediment Isopach Map 


\section{INTRODUCTION}

The purpose of this investigation is to identify potential sand sources for beach nourishment on the north end of Sand Key in Pinellas County, west-central Florida (Plate 1).' Much of Sand Key is considered a "critical erosion area" by the state's Department of Environmental Protection (Clark, 1992). This designation is used for "segments of the shoreline where substantial development or recreational interests are threatened by the erosion processes." Since the late 1960's, various segments of Sand Key have been nourished, including Indian Rocks Beach, Indian Shores, and North Redington Beach (Loeb, 1994). A primary source of sand for these nourishment projects has been the ebb tidal delta on the north side of the main Egmont channel. The primary Egmont borrow area is $\mathbf{2 0}$ miles away from the northern end of Sand Key. Future nourishment projects on the north end of Sand Key . would benefit from a closer borrow area. Location of a closer source of sand could result in significant savings in cost.

A previous investigation offshore of Sand Key identified limited sand resources in the adjacent vicinity. A survey conducted in the early 1980's extended approximately 5 miles offshore of Sand Key (D. Rosen, unpub. mapping, 1984). This survey found a thin sand cover approximately $2-4 \mathrm{ft}$ thick over most of the area and several sand ridges extending nearly perpendicular to shore that had sand up to $15 \mathrm{ft}$ thick. This previous study showed a potential sand resource offshore of Sand Key. The purpose of the present investigation is to further identify sand sources in this region.

Two areas, marked A and B in Plate 1, have been selected for detailed geophysical and vibracoring surveys. Area $A$ is approximately 12 miles long and one mile wide and extends along most of the length of Sand Key from just north of John's Pass to just south of Clearwater Pass. Area B is 6 miles long and one mile wide and is located offshore of area A along the northern part of Sand Key. The geophysical surveys were used to identify potential sand deposits and to select sites for vibracoring. Twenty-two vibracore sites were selected based on these geophysical surveys, as well as previously gathered data. 


\section{METHODS}

GEOPHYSICAL SURVEYS

A total of 135 trackline nautical miles of seismic reflection and side-scan sonar data were collected on October 12-13, 1994 using the Florida Institute of Oceanography vessel R/V Suncoaster (Plate 2). The geophysical instrumentation were deployed at the same time and included a high-resolution "boomer" type seismic system and an EG\&G side-scan sonar. Tracklines were run in the defined survey areas A and B at a $1000 \mathrm{ft}$ spacing. Navigation was by differential GPS, WGS84 datum, using the differential correction broadcast by the USCG from Egmont Key. Time (GMT), latitude and longitude were logged at 1 minute intervals by computer, annotated on seismic profiles and recorded with seismic shot headers at 1 minute intervals, and annotated on the side scan records every two minutes. The side scan data were recorded on $8 \mathrm{~mm}$ tape in EG\&G format and include navigation fixes approximately every 2 seconds.

Navigation data were post-cruise processed to remove bad fixes and to correct for the offset between the GPS antenna and the survey equipment location. The final navigation used for mapping has an accuracy estimated at 20-30 feet.

\section{High-Resolution Seismic Survey}

\section{Acquisition}

Seismic data were recorded using a digital, single-channel acquisition system. This included a HUNTEC Sea Otter boomer source powered at 135 Joules, an ITI 10-channel streamer with 4 adjacent channels selected for this survey, and an Elics Delph2 digital acquisition and processing package. Digital acquisition parameters were set at a $400 \mathrm{~ms}$ shot rate, $150 \mathrm{~ms}$ record length, and $10,000 \mathrm{~Hz}$ sample rate. Separation between the Huntec source and streamer was approximately 5 feet. 


\section{Processing}

All seismic data were processed using the Elics Delph2 system at USF with the objective of enhancing resolution of the thin sedimentary cover in the survey area. Pertinent processing parameters found to work best were $1000-3500 \mathrm{~Hz}$ bandpass filter, the Elics ADD AGC (gain), stacking 3 shots, and positive polarity display. Reflector resolution to 0.5 milliseconds ( $-1 \mathrm{ft}$.) was obtained.

\section{Interpretation}

The seismic data were used to map sediment thickness in the survey area and to choose targets for vibracoring. Sediment thickness estimates were compared to results from vibracore and jet probe penetrations. Good agreement was found between predicted and actual measurements. Seismic interpretation also incorporated information on rock or sediment at the seafloor as determined from side scan sonographs. Interpreted seismic profiles were digitized to output a file of time of day and sediment thickness measurements in milliseconds. Times were merged with the corrected navigation to calculate positions, and thickness in ms was converted to feet using a sound velocity of $5250 \mathrm{ft} / \mathrm{s}$. The sediment isopach map was drawn by hand using 4 overlays of, in order of importance, the actual digitized values, the side scan interpretation map showing rock outcrop and sediment-covered areas, a computer generated contour map of sediment thickness based on a gridded cell size of about $350 \mathrm{ft}$, and bathymetry from NOAA Chart 11412. Actual digitized values took precedence and the smoothing of values inherent in computer contouring was eliminated. Where the side scan sonographs indicated oriented bedform topography, such as in the southern portion of area $\mathrm{A}$, that trend was applied as a bias for contouring where small scale variability was noticeable.

\section{Side-Scan Sonar Survey}

An EG\&G side scan sonar was deployed to help define the spatial extent of unconsolidated sediment and hardbottoms in the study area. An EG\&G 272-TD towfish was 
operated at $100 \mathrm{kHz}$ with a total swath of $300 \mathrm{~m}(984 \mathrm{ft})$, or $150 \mathrm{~m}(492 \mathrm{ft})$ on a side. Digital side scan data were taped on an EG\&G 380 Exabyte unit.

Side scan data were used to map the distribution of sediment and rock in the study area (Plate 3). The technique used was to "paint in" a $300 \mathrm{~m}$ (984 ft) swath display of the cruise track. Three bottom types were identified: 1) a coarse, irregular high backscatter bottom return, 2) a low backscatter return, and 3) a high backscatter return but smoother bottom. These three acoustic patterns are inferred to be sediment, rock (hardground), and other (uncertain), respectively (Figure 1). Experience has shown us that rock/hardbottom exposures exhibit a distinctive coarse, high-backscatter image, while unconsolidated sediments typically exhibit low backscatter, with or without bedforms. A third type mapped exhibited a highbackscatter bottom but smoother and may not have been rock. This "other" type occurred in the southern portion of the study area and often correlated to rock interpreted on adjacent . lines.

\section{VIBRACORE SAMPLING}

A total of 20 sites were originally selected for vibracoring. Site selection was based upon seismic and side scan sonar data collected for this project as well as previously collected geophysical data. Sites were selected in what were interpreted to represent thick sediment accumulations. Most sites were on bathymetric highs that were interpreted from the seismic data to represent sediment accumulations, whereas others were located in subbottom depressions believed to represent sediment fill. Seismic expressions of core sites are shown in Appendix A1. Due to poor recovery at a few sites and additional side-scan sonar data, an additional two sites were added, making a total of 22 sites occupied (Plate 2).

Field

All vibracoring was conducted aboard the USGS vessel R/V G. K. Gilbert during October - December, 1994. Navigation was by a Trimble NavGraphic GPS used in differential mode. It is estimated that cores were collected within twenty feet of the GPS antennae and that accuracy of the differential GPS was between 10-15 feet. The vibracoring 


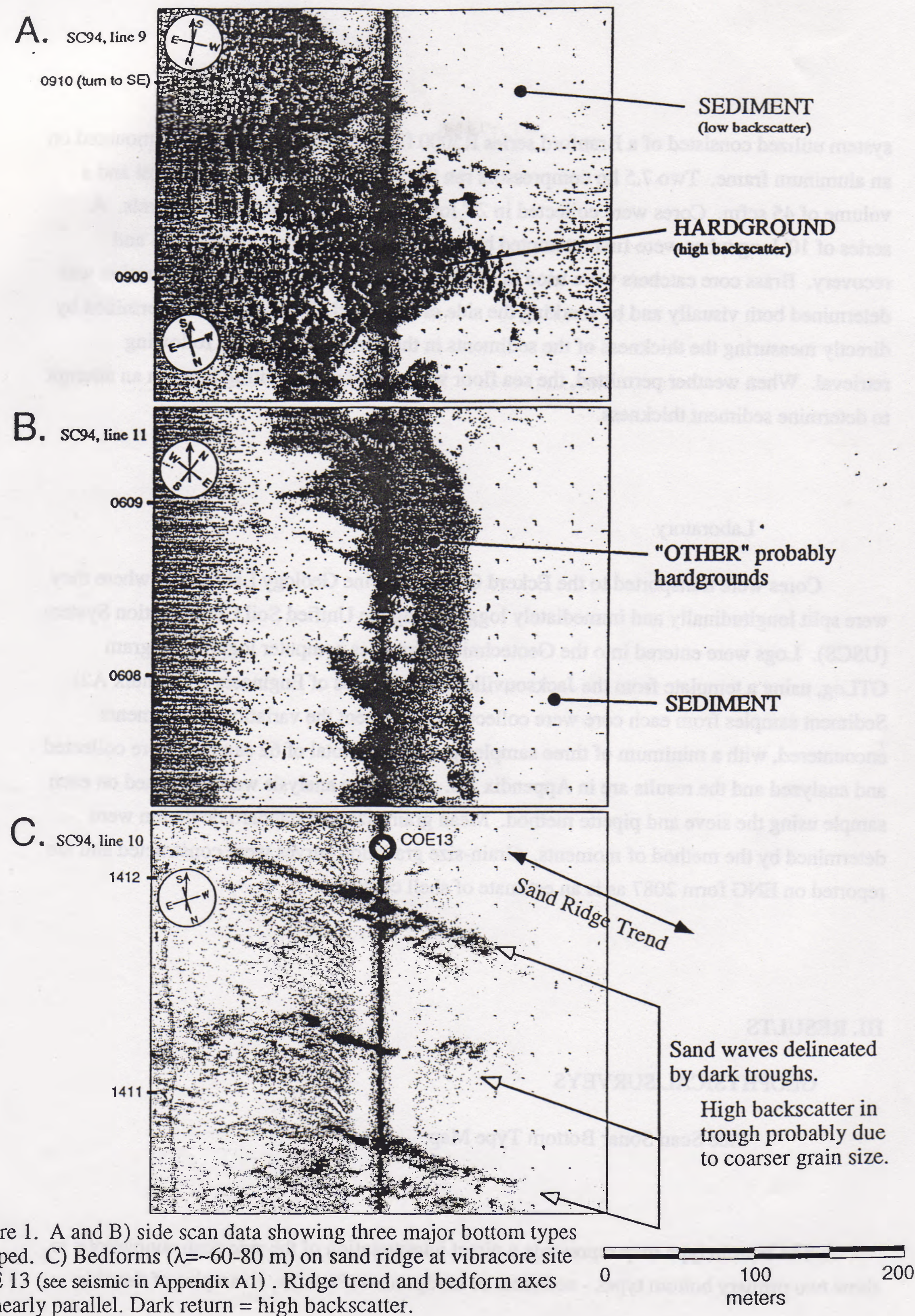


system utilized consisted of a Branford series R5000 flange-mount vibrating head mounted on an aluminum frame. Two $7.5 \mathrm{hp}$ compressors ran the vibrator at a pressure of $60 \mathrm{psi}$ and a volume of $45 \mathrm{scfm}$. Cores were collected in $20^{\prime}$ long $\times 3^{\prime \prime}$ diameter aluminum barrels. A series of $10^{\prime}$ long tubes were first attempted but abandoned due to poor penetration and recovery. Brass core catchers were used in all cases to insure full recovery. Penetration was determined both visually and by marking the side of the barrel. Recovery was determined by directly measuring the thickness of the sediments in the barrel immediately following retrieval. When weather permitted, the sea floor was probed with a jetting lance in an attempt to determine sediment thickness.

\section{Laboratory}

Cores were transported to the Eckerd College Marine Geology Laboratory where they were split longitudinally and immediately logged using the Unified Soil Classification System (USCS). Logs were entered into the Geotechnical Graphics computer logging program GTLog, using a template from the Jacksonville District Corps of Engineers (Appendix A2). Sediment samples from each core were collected to represent the variation of sediments encountered, with a minimum of three samples per core. A total of 62 samples were collected and analyzed and the results are in Appendix A3. Grain-size analysis was performed on each sample using the sieve and pipette method. Mean grain size and standard deviation were determined by the method of moments. Grain-size gradation curves were constructed and are reported on ENG form 2087 as is an estimate of shell content.

\section{RESULTS}

\section{GEOPHYSICAL SURVEYS}

Side Scan Sonar Bottom Type Map

The bottom type map represents a direct interpretation of the side scan sonographs to show two primary bottom types - sediment or hardground (Plate 3). Examples of the side 
scan data are shown in Figure 1. Side scan images suggest hardgrounds are extensive, with sand occurring as positive relief lenses or ridges above a relatively flat bedrock surface that is exposed between the sediment accumulations. Bathymetry is often a good indicator of sand or rock, the lows being hardbottom, and highs correlating to a sandy bottom. The side scan interpretation was used to aid and verify seismic interpretations and to guide sediment thickness contouring.

Several observations can be made based on the side scan data. In the northern part of the study area (survey areas B and north part of A) sediments occur in large-scale ridge deposits trending NW-SE. These deposits are on the order of $1 \mathrm{~km}$ wide and extend for several kilometers. The sediment cover increases in an onshore direction and is mostly continuos near the beach. Toward the southern part of area A more complex side scan backscatter patterns are observed. This appears to reflect a thinner sediment cover over the rock surface, although some thicker deposits do occur. Additionally, east-west lineation patterns are more common associated with large bedforms and perhaps a more mobile substrate.

\section{Sediment Thickness Map}

The sediment thickness map represents an integration of all available data on sand thickness and trends (Plate 4). It should be viewed as a conservative estimate of sediment thickness that would correlate with the upper clean quartz sand unit recovered in the cores. Thickest sediment accumulations occur in the northern and far southern portions of the study area in the form of WNW-ESE trending ridges. Almost all of the sediment thickness is due to positive relief accumulation above the generally flat rock surface in this area.

Although the bedrock surface underlying the shelf sediments is generally flat, a few subsurface lows contained unconsolidated sediments penetrated by coring. Examples of this are found in vibracores 9 and 10. However these type of deposits are uncommon and restricted in extent. Where cores penetrated the upper sand unit and encountered organic-rich sediments or other sediment types, a seismic reflector was sometimes evident (see Appendix A). These reflectors typically matched the elevation of the surrounding rock surface. The 
interpretive approach used here tended to exclude the presence of these deeper style deposits in the isopach map. In general, sediment thickness on the seismic records was determined to be from the seafloor to the first subbottom return.

Finally, the isopach map represents a significant smoothing of the true variability in thickness due to the depositional geometries. The larger sand ridges themselves are mantled by large sand waves creating highly variable relief (and associated thickness variability) (for example, see Appendix A1 core 13).

\section{VIBRACORES}

A summary of the vibracoring cruise log is given in Table 1. Core penetration ranged from 2 ' to $14^{\prime}$. Recovery ranged from 0 to $12.5^{\prime}$. Jetted depth to refusal ranged from $5.3^{\prime}$ to 16.7'. The percent of sediment recovered versus penetration ranged from $65 \%$ to $93 \%$. The difference between the amount recovered and that penetrated was mostly due to compaction of the sediments in the core. Longest cores $\left(>7^{\prime}\right)$ were collected from sites $1,6,8,9,13,16$, 17,18 , and 22; most of which are in the northern and inshore portion of the study area. Eight cores (sites 1, 3, 8, 9, 11, 13, 21, and 22) had the bottoms of the barrels chewed up as if encountering a hard refusal layer. Eight cores (sites 1,3,9,10,12,13,15 and 21) contained limestone fragments wedged in the bottom. Three cores (sites 8, 10 and 18) contained a compact blue-gray clay in the bottom. Cores $4,9,11,13,17$, and 22 contained large shell fragments at the base. Core 14 contained a large quantity of blackened (phosphatic?) sand grains at the base.

\section{Core Logs}

Core logs are shown in Appendix A2. In general, seven basic lithologies are represented. Relatively clean, fine-grained quartz sand is the dominant lithology, generally occupying the uppermost portion of the cores. Thickest accumulations of clean sand were encountered in cores $6,9,13,17,18$, and 22; most of which are located in the northern portion of the study area. A mixture of quartz sand and shell fragments is common in layers that can be found at any depth downcore and throughout the study area. Quartz sands mixed with blackened grains (phosphorite?) were abundant in cores 4,11 and 14. These sediments were found most often in the central to southern part of the study area. Cores were generally 
quite short $\left(<3^{\prime}\right)$ and, at least in the case of core 14 , these blackened sands constitute refusal. Dark brown to black, organic-rich, fine-grained sediments were found in cores 6 and 16 in the northern portion of the study area. They generally occur as relatively thin layers near the core base. Thin layers of light-colored, lime mud were found near the base of cores 8 and 18, both located in the northern region. A hard, compact, blue-gray clay was found at the base of several cores (listed previously) and is thought to represent refusal. Large fragments of limestone found at the base of some cores (listed previously) is interpreted to represent refusal as the core penetrated the underlying limestone surface.

\section{Grain Size Analysis}

Grain size data for all sediment samples are presented in Appendix A3 and Table 2: These include two samples (15 and 19) that were collected directly from the sediment surface (i.e., there was no core retrieval). Mean grain size ranges from -0.7 phi (approximately 1.6 $\mathrm{mm}$; very coarse sand) to $6.2 \mathrm{phi}$ (approximately $0.015 \mathrm{~mm}$; medium silt). Most, however, are between 2 and 3 phi (fine sand), especially in the uppermost portions of the core. Standard deviation (a measure of sediment sorting) ranges from 0.8 to $3.8 \mathrm{phi}$, but the majority are in the 1 to 2 phi range indicating sediments are generally poorly sorted. Grain size gradation curves show that most samples fall into the fine sand-size category. This is especially true for the relatively clean quartz sand samples (described above), which are consistently composed of $50 \%$ to $80 \%$ fine sand. Sediments containing an appreciable amount of shell material, limestone fragments and/or blackened grains are consistently coarser. Sediment samples containing organic-rich material and the blue-gray clay layers (both of which are located near the bottom of some cores) are consistently finer. 
Table 1. Summary of Vibracore Sampling

\begin{tabular}{|c|c|c|c|c|c|c|c|c|}
\hline Core \# & $\begin{array}{l}\text { State Plane } \\
\mathbf{X} \text { (feet) } \\
\end{array}$ & $\begin{array}{l}\text { State Plane } \\
\mathbf{Y} \text { (feet) }\end{array}$ & $\begin{array}{l}\text { Water } \\
\text { Depth }\end{array}$ & $\begin{array}{l}\text { Core } \\
\text { Penetration }\end{array}$ & $\begin{array}{l}\text { Core } \\
\text { Recovery }\end{array}$ & \%Recovery & $\begin{array}{l}\text { Jet Probe } \\
\text { Depth }\end{array}$ & Comments \\
\hline COE-94-1(2)*^ & 193,223 & $1,310,701$ & $28.2^{\prime}$ & - & $10.5^{\prime}$ & - & 7.3' & \\
\hline COE-94-2(2) & 195,640 & $1,312,888$ & $23.5^{\prime}$ & - & $6.2^{\prime}$ & - & $10^{\prime}$ & \\
\hline COE-94-3(2)*^ & 199,634 & $1,314,366$ & $23.4^{\prime}$ & - & $5.4^{\prime}$ & - & $5.3^{\prime}$ & \\
\hline COE-94-4(2): & 190,929 & $1,296,199$ & $24^{\prime}$ & $6.4^{\prime}$ & $5.9^{\prime}$ & $92 \%$ & - & \\
\hline COE-94-5 & 199,756 & $1,310,663$ & $25^{\prime}$ & $2.4^{\prime}$ & - & - & - & Hardgrounds listed on navigation chart. \\
\hline COE-94-6(2) & 209,354 & $1,312,403$ & $22^{\prime}$ & $14^{\prime}$ & $12.5^{\prime}$ & $89 \%$ & $16.7^{\prime}$ & Muddy, organic material at core bottom. \\
\hline COE-94-7 & 197,476 & $1,301,045$ & $21^{\prime}$ & $<1^{\prime}$ & - & - & - . & Attempted 3 times, penetration $<1$, no recovery. \\
\hline COE-94-8(2)*- & 210,621 & $1,310,539$ & $18^{\prime}$ & - & 9.6 & - & $8.5^{\prime}$ & \\
\hline COE-94-9(2)*^: & 208,502 & $1,294,641$ & $19^{\prime}$ & $10.5^{\prime}$ & $8.1^{\prime}$ & 77\% & - & \\
\hline COE-94-10(2) & 209,027 & $1,291,347$ & $22^{\prime}$ & $2.5^{\prime}$ & $2.8^{\prime}$ & $93 \%$ & - & This site was cored 2 times. \\
\hline COE-94-11(2)* & 218,222 & $1,263,823$ & 14 & $4^{\prime}$ & $2.9^{\prime}$ & $73 \%$ & - & \\
\hline COE-94-12 & 221,870 & $1,258,525$ & $14.8^{\prime}$ & $8^{\prime}$ & $6.2^{\prime}$ & $78 \%$ & - & \\
\hline COE-94-13(2)^ & 213,024 & $1,310,073$ & $19^{\prime}$ & - & $9.5^{\prime}$ & - & $5.5^{\prime}$ & \\
\hline COE-94-14 & 219,815 & $1,262,860$ & $11.8^{\prime}$ & $4^{\prime}$ & $2.6^{\prime}$ & $65 \%$ & 8.3' & \\
\hline COE-94-15(2)^ & 217,193 & $1,320,393$ & $16^{\prime}$ & 3.5' & +++ & - & $5.3^{\prime}$ & Limestone in core catcher. \\
\hline COE-94-16 & 214,074 & $1,308,702$ & $16^{\prime}$ & $9^{\prime}$ & $7.9^{\prime}$ & $88 \%$ & - & \\
\hline COE-94-17(2): & 226,036 & $1,257,745$ & $11^{\prime}$ & - & $7.7^{\prime}$ & - & - & \\
\hline COE-94-18(2) & 216,612 & $1,309,132$ & $15^{\prime}$ & $12^{\prime}$ & $9.5^{\prime}$ & $79 \%$ & - & \\
\hline COE-94-19(2B) & 216,311 & $1,279,204$ & $15^{\prime}$ & $4^{\prime}$ & +++ & - & - & Attempted 3 times. \\
\hline COE-94-20 & 199,811 & $1,310,838$ & $24^{\prime}$ & $\mathbf{2}^{\prime}$ & - & - & - & Hardgrounds listed on the navigation chart. \\
\hline COE-94-21*^ & 205,547 & $1,308,480$ & $23^{\prime}$ & - & - & - & - & Limestone in core catcher. \\
\hline COE-94-22*: & 210,794 & $1,288,546$ & $17^{\prime}$ & $9.5^{\prime}$ & $7.9^{\prime}$ & $83 \%$ & $=$ & \\
\hline
\end{tabular}

* Bottom of core barrel banged up.

$\sim$ Blue-gray clay layer found at base of core.

$\wedge$ Limestone fragments at base of core.
+++ No core, sample bag only.

: Gravel size shells in core bottom.
- No data.

(2) Second time site occupied.

(2B) Second attempt at same site. 
Table 2. Grain Size Statistics

\begin{tabular}{|c|c|c|c|c|c|c|c|}
\hline CORE \# & $\begin{array}{l}\text { INTERVAL } \\
\text { (FEET) }\end{array}$ & $\begin{array}{l}\text { MEAN GRAIN } \\
\text { SIZE } \\
\text { (PHI) }\end{array}$ & $\begin{array}{l}\text { STANDARD } \\
\text { DEVIATION } \\
\text { (PHI) } \\
\end{array}$ & CORE\# & $\begin{array}{l}\text { INTERVAL } \\
\text { (FEET) }\end{array}$ & $\begin{array}{l}\text { MEAN GRAIN } \\
\text { SIZZE } \\
\text { (PHI) }\end{array}$ & $\begin{array}{l}\text { STANDARD } \\
\text { DEVIATION } \\
\text { (PHI) } \\
\end{array}$ \\
\hline COE-94-1(2) & $\begin{array}{l}2.0-2.1 \\
7.3-7.4 \\
8.7-8.8\end{array}$ & $\begin{array}{l}2.8 \\
2.3 \\
0.5\end{array}$ & $\begin{array}{l}1.1 \\
1.3 \\
2.0\end{array}$ & COE-94-12 & $\begin{array}{l}0.7-0.8 \\
3.2-3.3 \\
5.3-5.4\end{array}$ & $\begin{array}{l}1.6 \\
2.1 \\
-0.7\end{array}$ & $\begin{array}{l}1.2 \\
1.1 \\
1.6\end{array}$ \\
\hline COE-94-2(2) & $\begin{array}{l}1.0-1.1 \\
3.0-3.1 \\
5.0-5.1\end{array}$ & $\begin{array}{l}2.7 \\
1.7 \\
2.9\end{array}$ & $\begin{array}{l}0.9 \\
1.8 \\
1.0\end{array}$ & COE-94-13(2) & $\begin{array}{l}1.0-1.1 \\
6.5-6.6 \\
7.5-7.6 \\
8.48 .5\end{array}$ & $\begin{array}{l}3.0 \\
2.0 \\
1.1 \\
0.6\end{array}$ & $\begin{array}{l}1.7 \\
2.2 \\
2.3 \\
2.6\end{array}$ \\
\hline COE-94-3(2) & $\begin{array}{l}1.0-1.1 \\
3.5-3.6 \\
4.8-4.9\end{array}$ & $\begin{array}{l}2.3 \\
2.9 \\
-0.4\end{array}$ & $\begin{array}{l}1.2 \\
1.2 \\
2.1\end{array}$ & COE-94-14 & $\begin{array}{l}0.4-0.5 \\
1.3-1.4 \\
2.4-2.5\end{array}$ & $\begin{array}{l}1.9 \\
2.0 \\
1.5\end{array}$ & $\begin{array}{l}1.6 \\
1.6 \\
1.8\end{array}$ \\
\hline COE-94-4(2) & $\begin{array}{l}1.0-1.1 \\
3.9-4.0 \\
5.7-5.8\end{array}$ & $\begin{array}{l}2.4 \\
2.8 \\
0.9\end{array}$ & $\begin{array}{l}1.1 \\
1.0 \\
2.3\end{array}$ & COE-94-15(2) & & 2.1 & 1.6 \\
\hline COE-94-6(2) & $\begin{array}{l}1.0-1.1 \\
2.4-2.5 \\
7.5-7.6 \\
8.7-8.8 \\
10.7-10.8 \\
12.2-12.3\end{array}$ & $\begin{array}{l}3.0 \\
1.8 \\
2.1 \\
2.8 \\
6.2 \\
4.8\end{array}$ & $\begin{array}{l}1.3 \\
1.9 \\
2.3 \\
2.4 \\
2.2 \\
2.3\end{array}$ & COE-94-16 & $\begin{array}{l}0.1-0.2 \\
1.1-1.2 \\
4.2-4.3 \\
6.7-6.8 \\
7.7-7.8\end{array}$ & $\begin{array}{l}1.9 \\
2.6 \\
1.8 \\
2.8 \\
3.4\end{array}$ & $\begin{array}{l}1.3 \\
0.9 \\
1.7 \\
1.9 \\
2.0\end{array}$ \\
\hline COE-94-8(2) & $\begin{array}{l}1.5-1.6 \\
3.6-3.7 \\
7.6-7.7 \\
8.7-8.8\end{array}$ & $\begin{array}{l}2.8 \\
2.5 \\
2.0 \\
5.6\end{array}$ & $\begin{array}{l}1.3 \\
1.9 \\
3.1 \\
2.6\end{array}$ & COE-94-17(2) & $\begin{array}{l}0.2-0.3 \\
1.8-1.9 \\
4.0-4.1 \\
6.2-6.3\end{array}$ & $\begin{array}{l}2.0 \\
1.0 \\
2.4 \\
0.5\end{array}$ & $\begin{array}{l}1.2 \\
1.8 \\
0.9 \\
2.2\end{array}$ \\
\hline COE-94-9(2) & $\begin{array}{l}1.1-1.2 \\
3.8-3.9 \\
4.9-5.0 \\
5.8-5.9 \\
7.5-7.6\end{array}$ & $\begin{array}{l}2.8 \\
2.7 \\
2.3 \\
0.4 \\
-0.6\end{array}$ & $\begin{array}{l}1.0 \\
1.0 \\
1.1 \\
1.8 \\
1.9\end{array}$ & COE-94-18(2) & $\begin{array}{l}2.0-2.1 \\
6.4-6.5 \\
8.0-8.1 \\
9.2-9.3\end{array}$ & $\begin{array}{l}2.4 \\
3.2 \\
1.4 \\
3.1\end{array}$ & $\begin{array}{l}1.1 \\
2.1 \\
2.4 \\
1.7\end{array}$ \\
\hline COE-94-10(2) & $\begin{array}{l}0.4-0.5 \\
1.1-1.2 \\
2.2-2.3\end{array}$ & $\begin{array}{l}2.7 \\
1.0 \\
4.3\end{array}$ & $\begin{array}{l}1.3 \\
1.9 \\
3.8\end{array}$ & $\begin{array}{l}\text { COE-94-19(2) } \\
\text { COE-94-19(2B) }\end{array}$ & & $\begin{array}{l}2.6 \\
3.0\end{array}$ & $\begin{array}{l}1.1 \\
1.5\end{array}$ \\
\hline COE-94-11(2) & $\begin{array}{l}0.5-0.6 \\
1.6-1.7 \\
2.7-2.8\end{array}$ & $\begin{array}{l}2.4 \\
1.3 \\
1.1 \\
\end{array}$ & $\begin{array}{l}1.4 \\
2.2 \\
2.3 \\
\end{array}$ & COE-94-22 & $\begin{array}{l}1.0-1.1 \\
4.8-4.9 \\
7.3-7.4\end{array}$ & $\begin{array}{l}2.8 \\
2.3 \\
1.2 \\
\end{array}$ & $\begin{array}{l}0.8 \\
1.1 \\
1.6\end{array}$ \\
\hline
\end{tabular}




\section{INTERPRETATION}

Vibracoring results suggest that the majority of unconsolidated sediment was penetrated by the corer and retrieved. The $65 \%$ - $93 \%$ recovery rate is consistent with this type of coring technique and is interpreted to be a result of sediment compaction. A comparison of the core recovery to the jetted depth (Table 1) indicates that for most sites the core bottomed out within two feet of the jetted depth. In three instances, however, the core penetrated deeper than was jetted, indicating that jetting did not always reach the refusal depth. The ten cores that contained limestone fragments and/or blue-gray clay at their bases, are interpreted to have penetrated the entire thickness of surficial unconsolidated sediments. The limestone fragments indicate penetration into a lithified or semi-lithified surface. The blue-gray clay probably represents the top of the Hawthom Formation, a phosphatic limestone deposited during the Miocene (Stahl, 1970; Campbell, 1973; Brooks and Doyle, 1989). This blue-gray clay is quite distinctive and has been encountered throughout the Tampa Bay region. The cores bottoming out in the coarse shell layer may have penetrated the entire thickness of the surficial sediment layer as core logs show that it is quite common to encounter a coarse shell layer immediately above (or even in addition to) the limestone or blue-gray clay (Appendix A2). Evidence is purely circumstantial at this point, however, as shell layers are encountered at all depths. Sediments rich in blackened grains were found to be unrecoverable or yielded short cores. The reason for this is unknown but previous workers have suggested that blackened grains consist of phosphorite that has been winnowed from the underlying Hawthom Formation (Doyle and Sparks, 1980). A reasonable interpretation is that sediment cover may be very thin in these areas.

Of the longest cores retrieved, most (cores 1, 6, 8,13, and 18) were consistently located in a relatively confined zone in the northernmost portion of the study area (Plate 2). These cores also exhibited the thickest layers of relatively clean quartz sand, which was consistently found on, or near, the surface. The interpretation is that this area exhibits the thickest accumulation of unconsolidated surface sediments, including the thickest deposit of relatively clean, quartz sand. Seismic and vibracore data show that the bottom is represented by a series of roughly parallel, northwest-southeast trending sand ridges. The largest of these sand ridges in the study area is roughly 1 mile wide by 5 miles long. Whether they are presently mobile is unknown. 
Our recommendation at this stage is that future work be focused on these sand ridges, or similar features identified within the study area. Future studies should address the geologic history of these sand ridges, as well as, whether modern processes play a role in modifying these features.

\section{ACKNOWLEDGEMENTS}

This work was primarily funded by the U.S. Army Corps of Engineers, Jacksonville District, and supplemented by funds from the U.S. Geological Survey's Marine and Coastal Program. We wish to thank the captain and crew of the R/V Suncoaster for their help in collecting the geophysical data, and the captain of the R/V Gilbert for his help in collecting the vibracores. We also want to thank Nancy DeWitt, Jim Edwards, Sean Leatham, and . Kevin Geraghty for their help in collecting and processing the vibracores. Finally, we thank Mark Hansen and Jennifer Bexley for producing the maps. 


\section{REFERENCES}

Brooks, G.R. and L.J. Doyle, 1989, Recent Geological History of Mud-Dominated Sediments in Hillsborough Bay, Florida: Final Report to City of Tampa, 58 pp.

Campbell, K.M., 1973, Geology of Hillsborough County: Florida Bureau of Geology, Tallahassee, $17 \mathrm{pp}$.

Clarke, R. R., 1992, Beach Conditions in Florida: A Statewide Inventory and Identification of the Beach Erosion Problem Areas in Florida, Beaches and Shores Technical and Design Memorandum 89-1, 4th edition, 208 pp.

Doyle, L.J. and Sparks, T.N. 1980, Sediments of the Mississippi, Alabama and Florida (MAFLA) continental shelf: Joum. Sed. Pet., v. 50, p. 905-916.

Loeb, W. A., 1994, Beaches of Pinellas County, Florida: A History of their Comings and Goings (circa 1950 - present), U. S. Geological Survey, Open-File Report 94-565.

Stahl, L.E., 1970, The marine geology of Tampa Bay (M.S. Thesis): Florida State University, Tallahassee, $69 \mathrm{pp}$. 
APPENDIX A1

Seismic Segments at Core Sites 


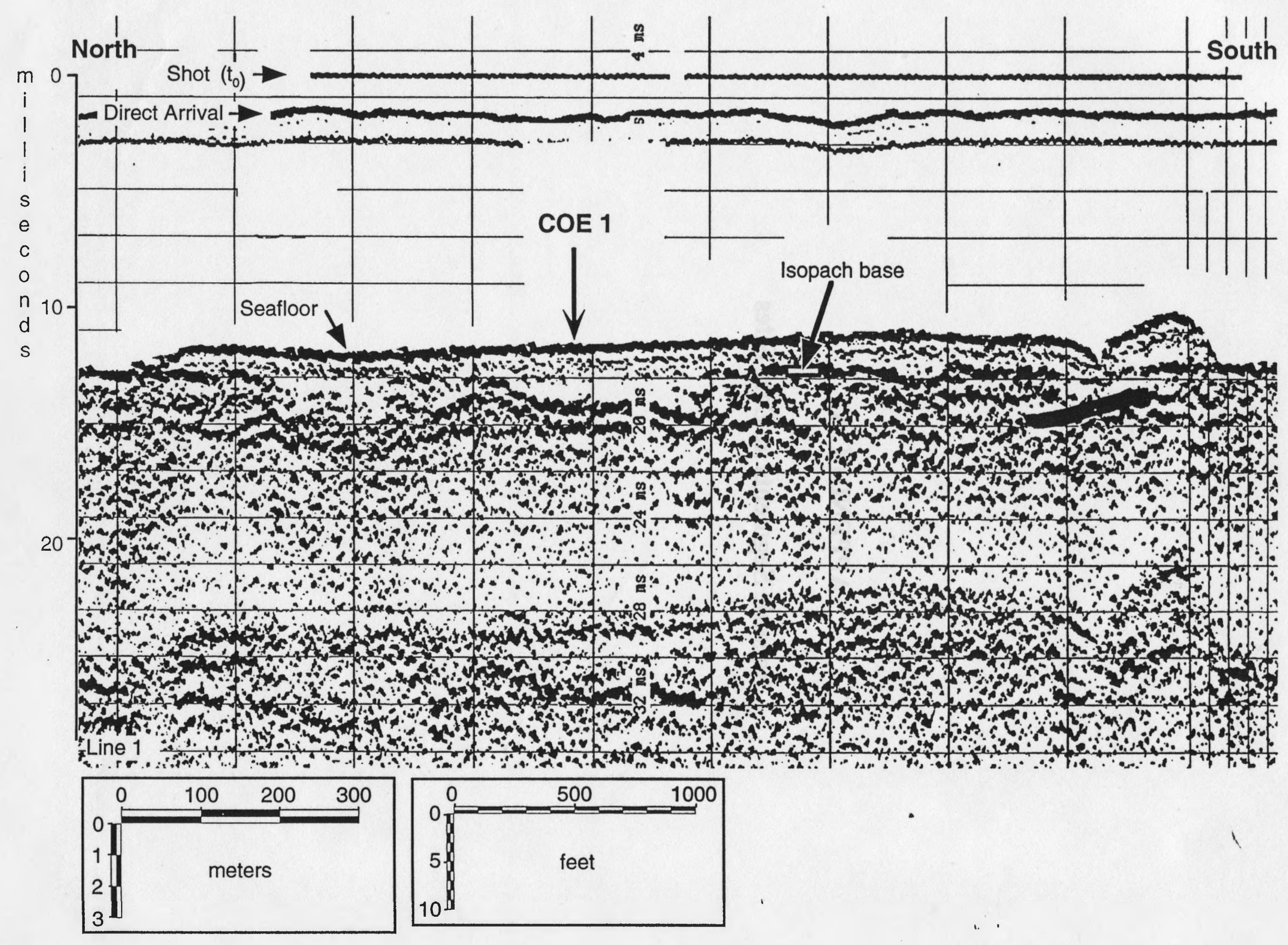




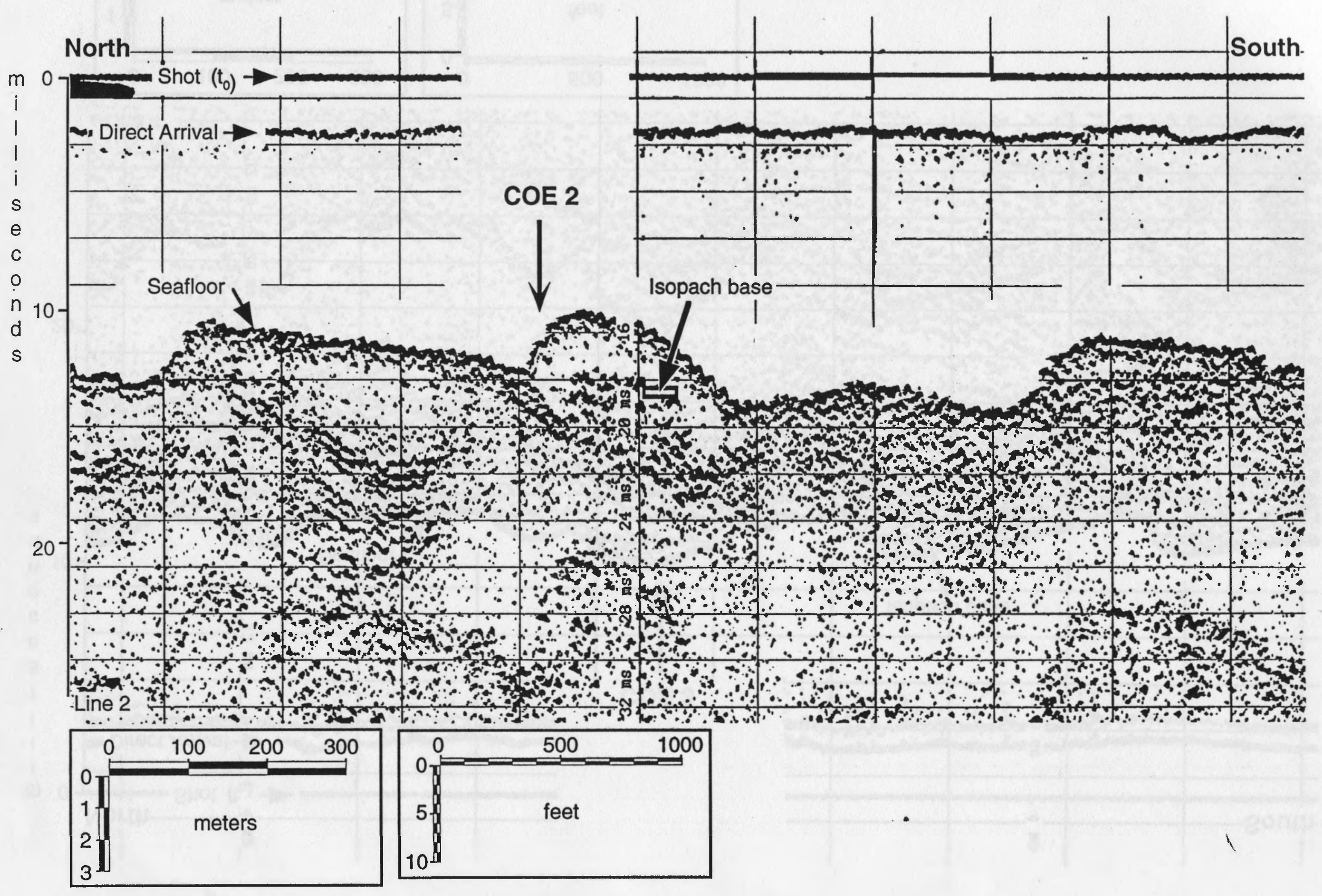




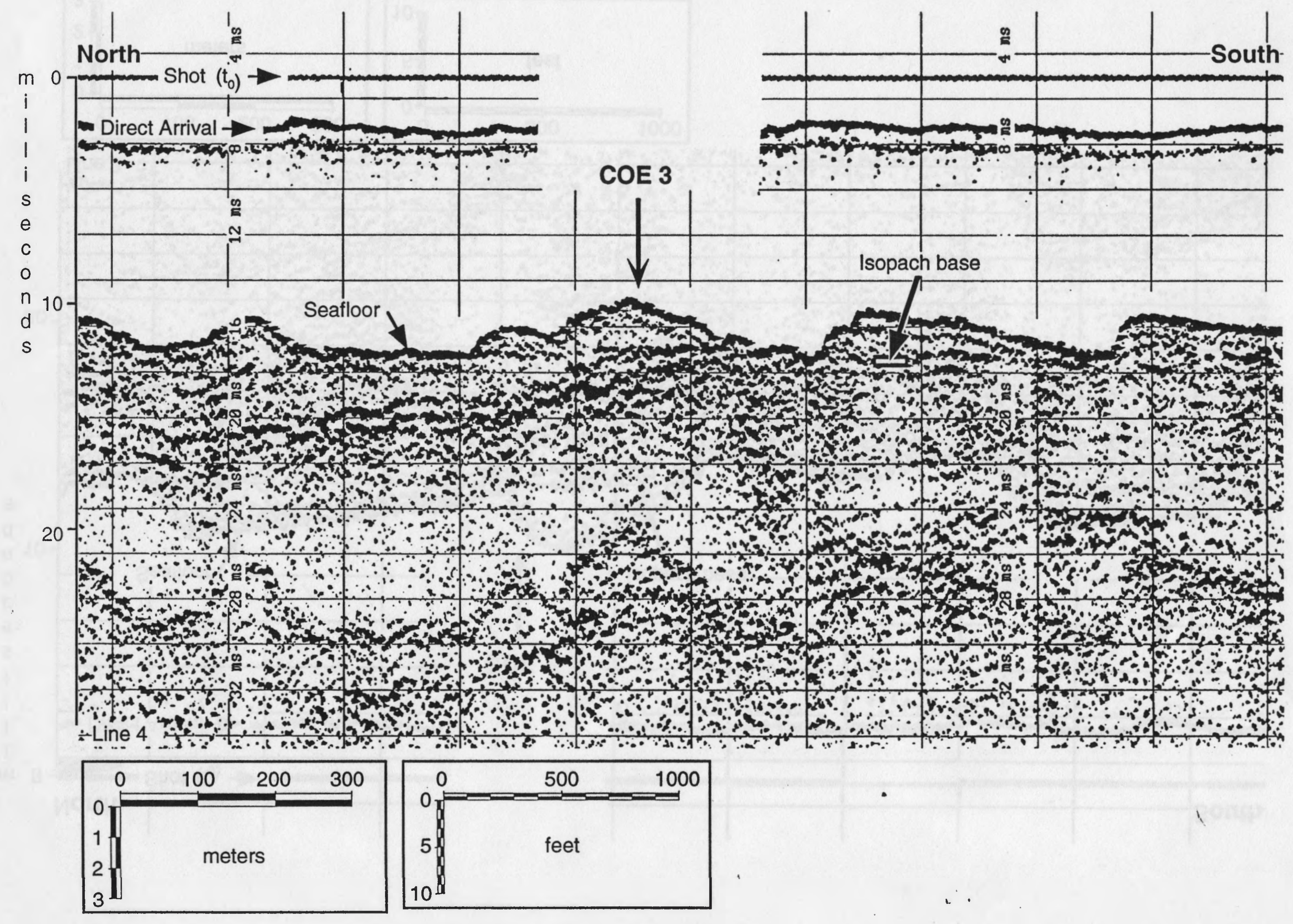




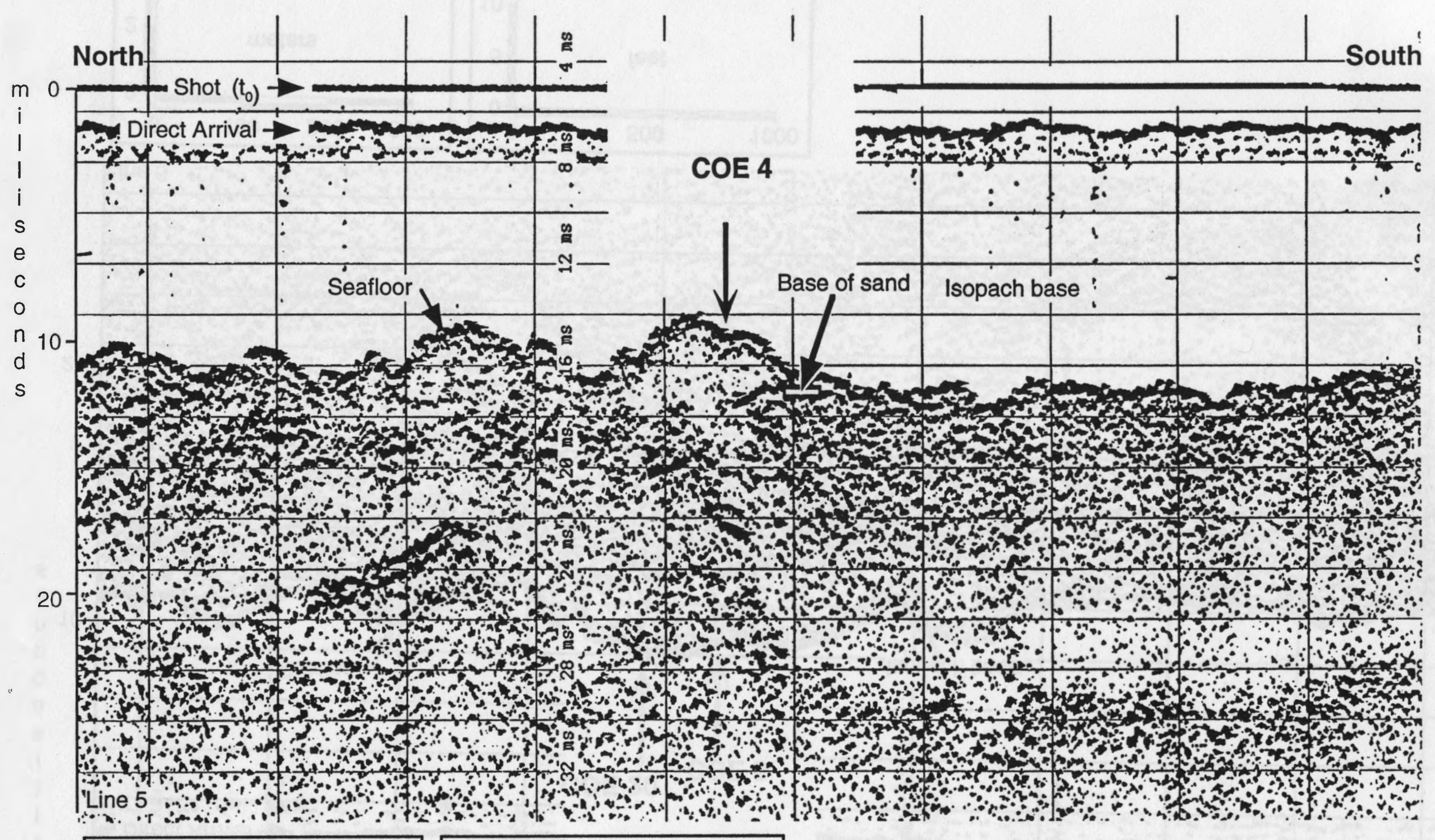

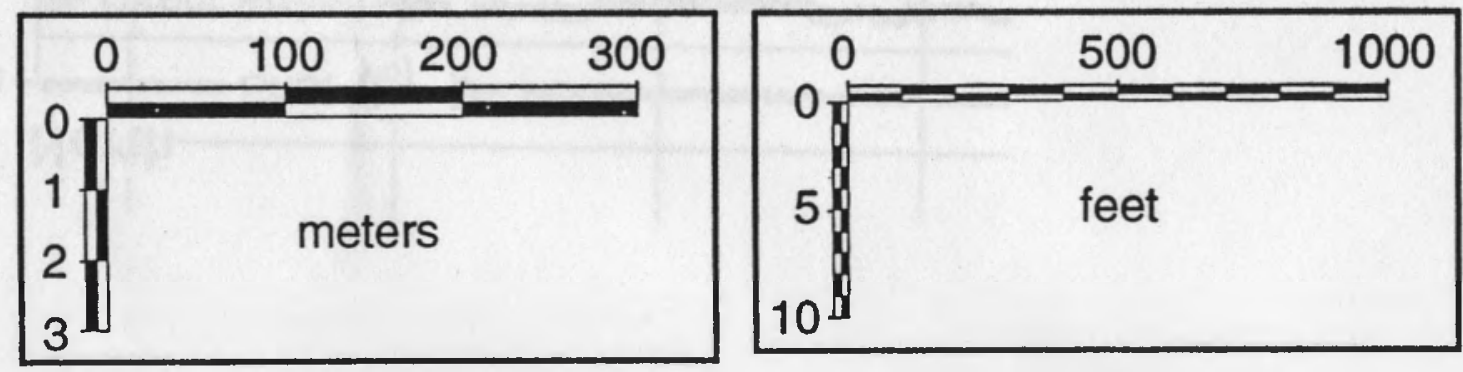




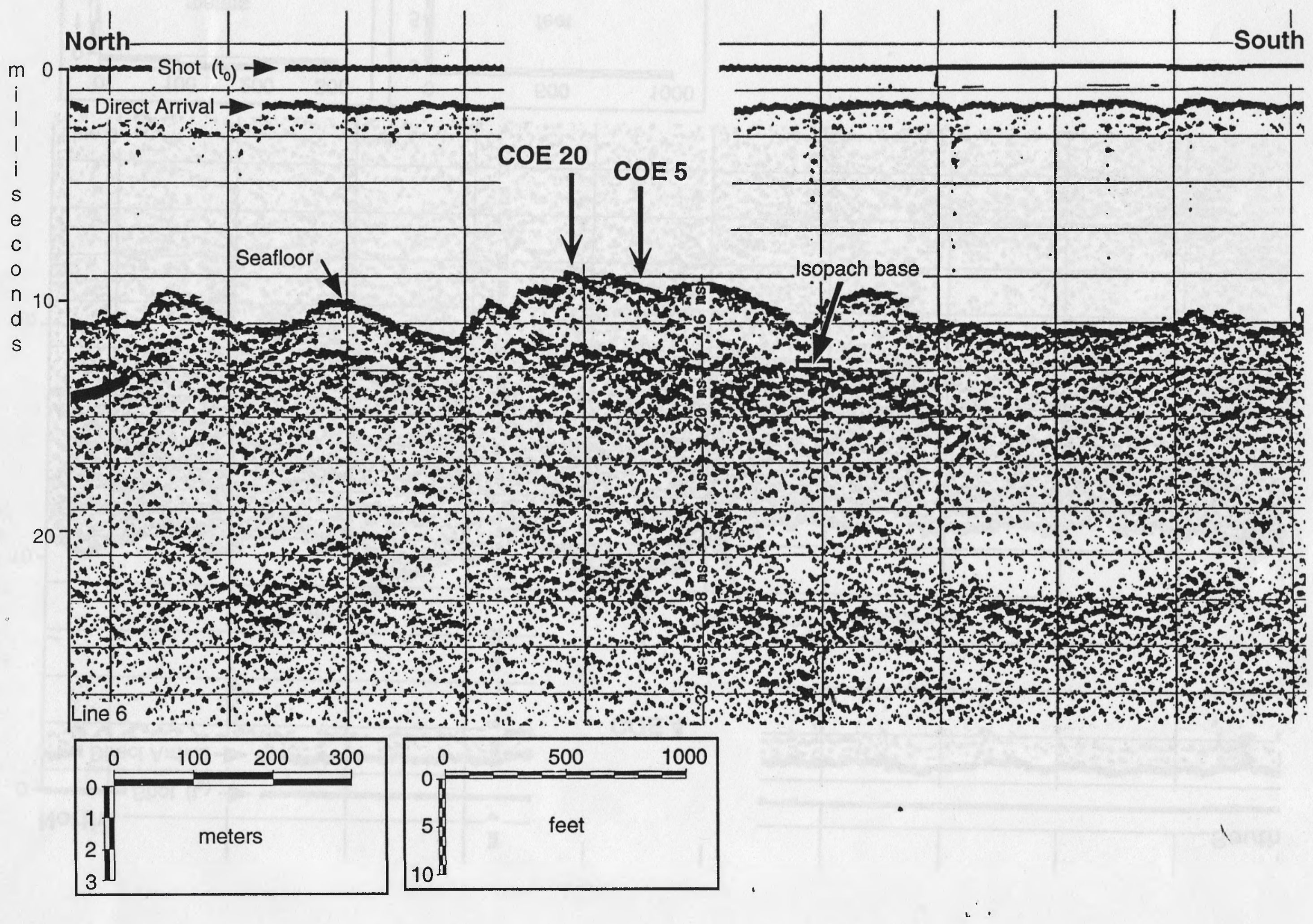



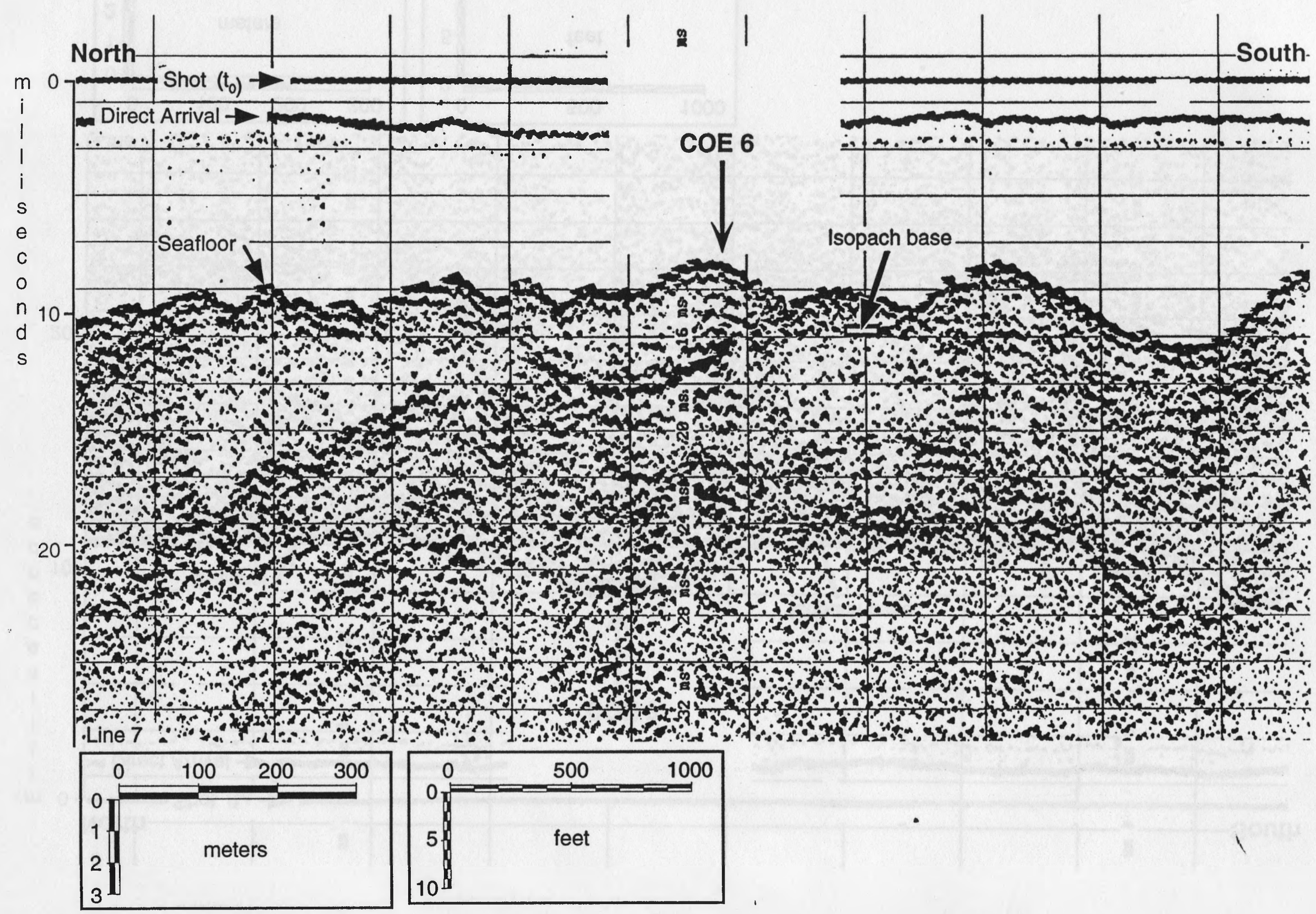

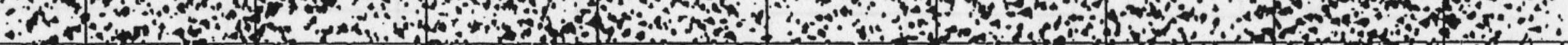

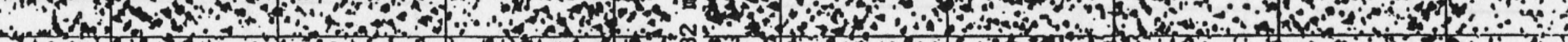

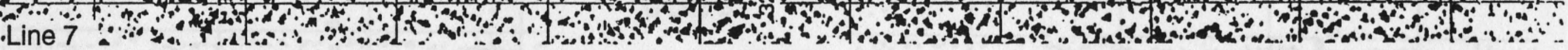

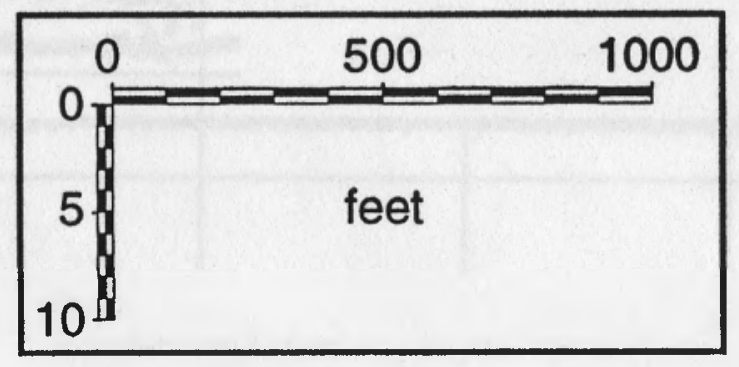




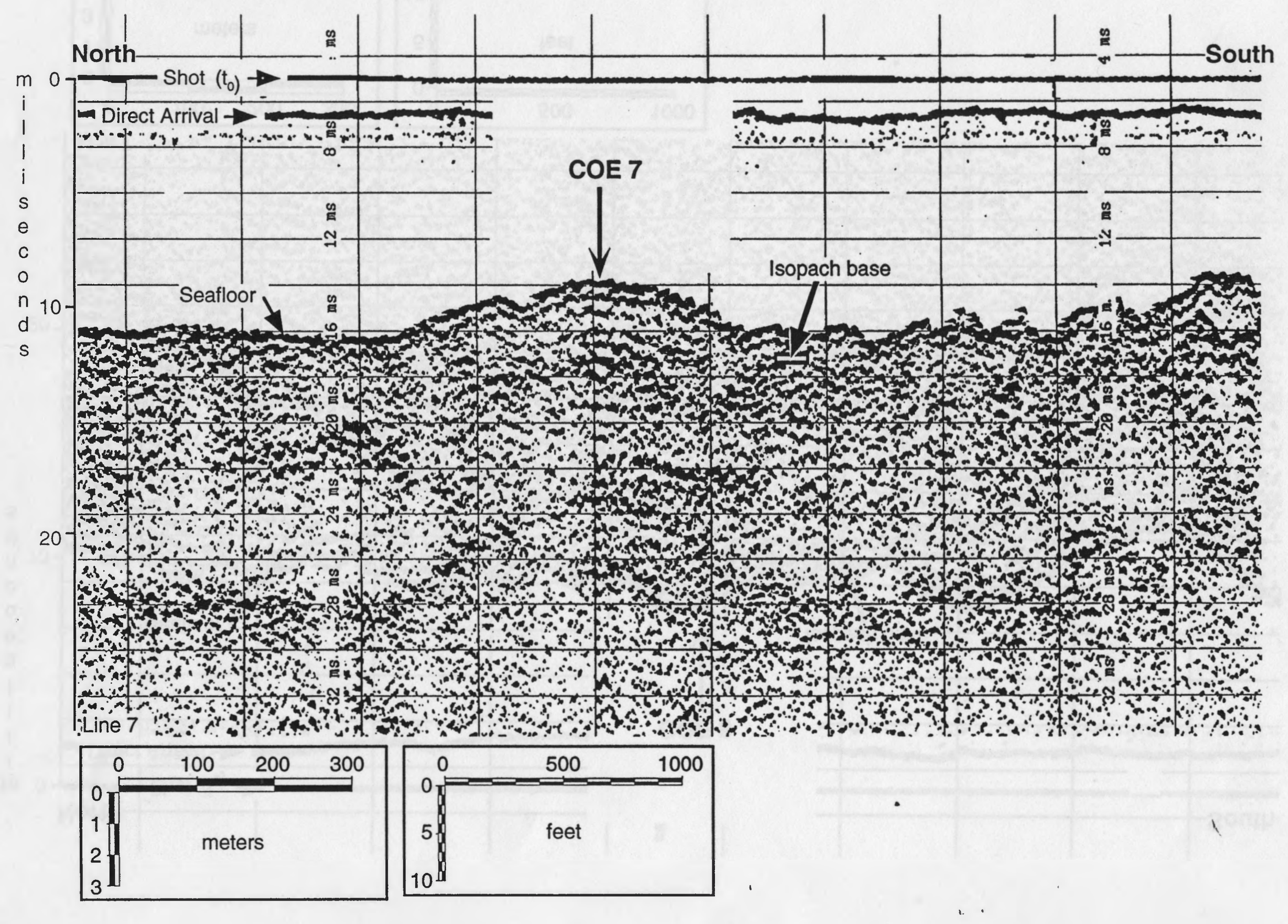




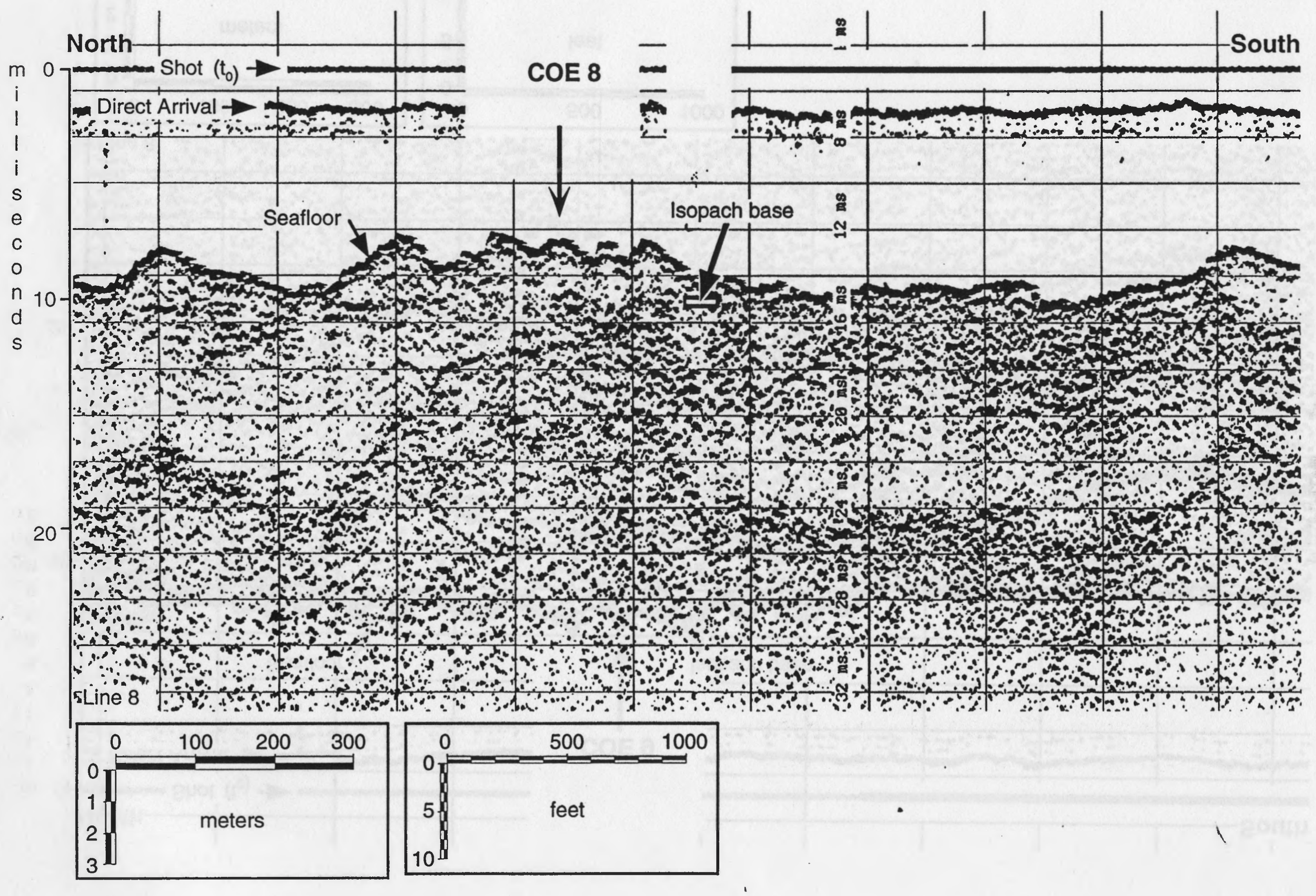




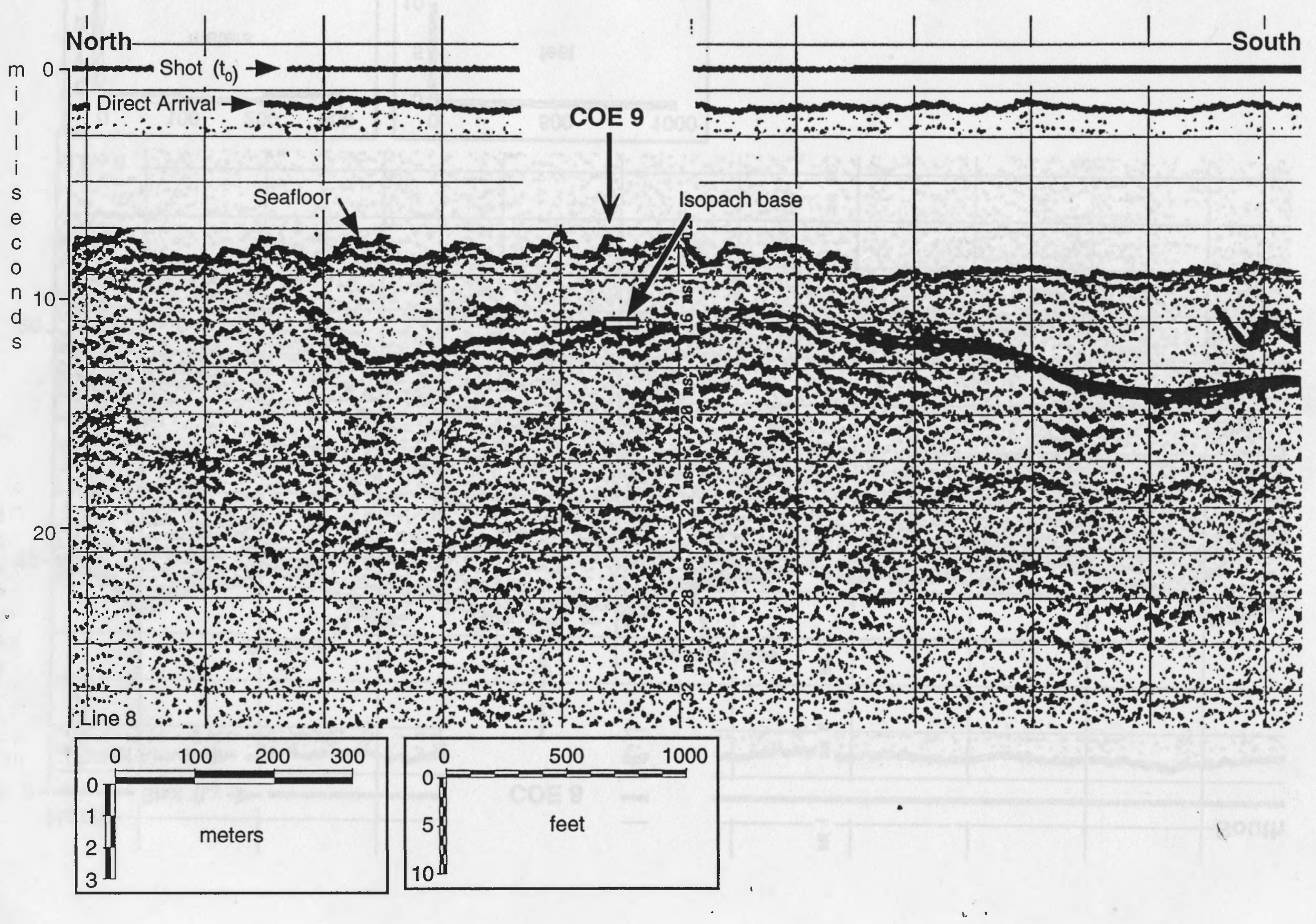




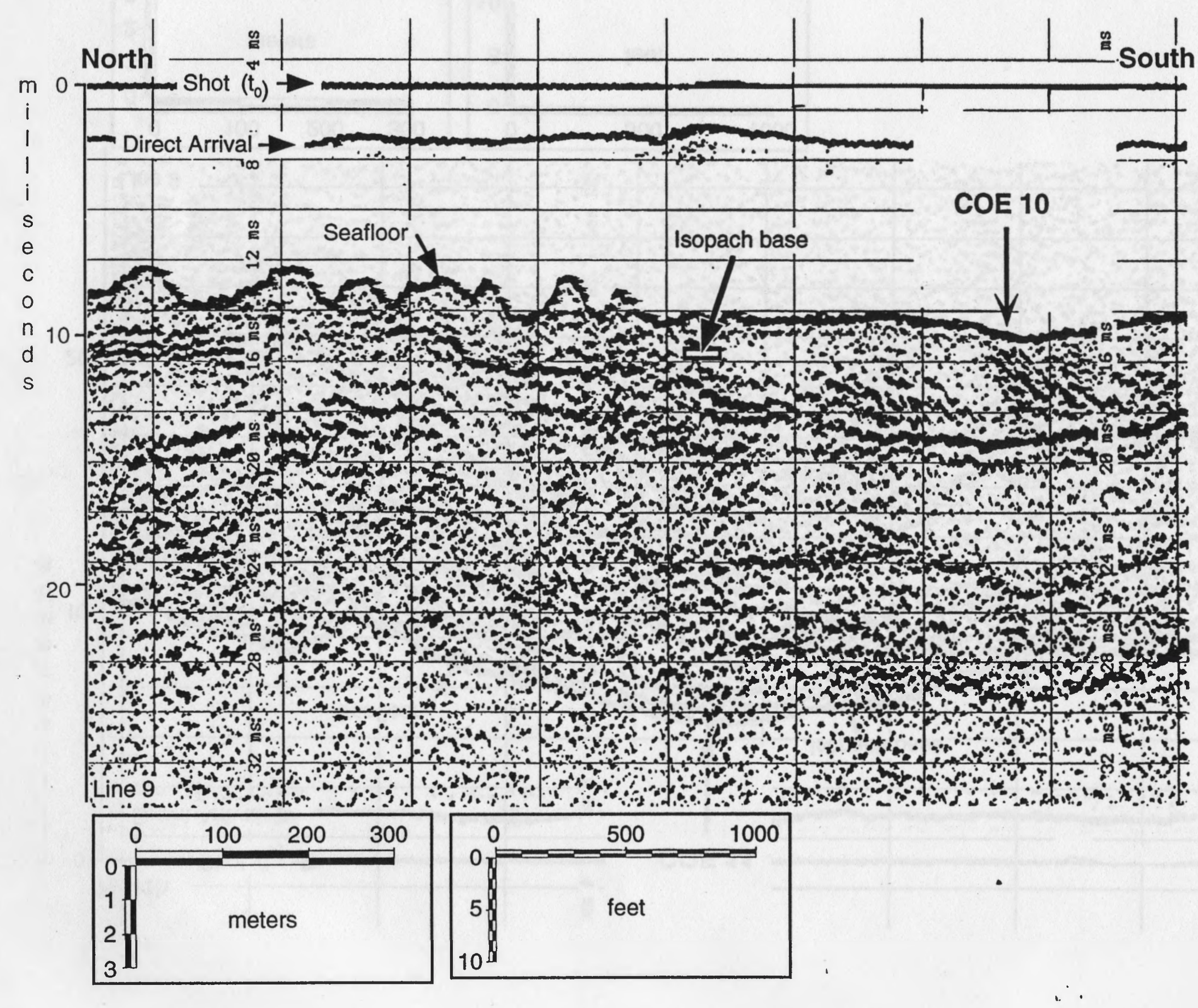




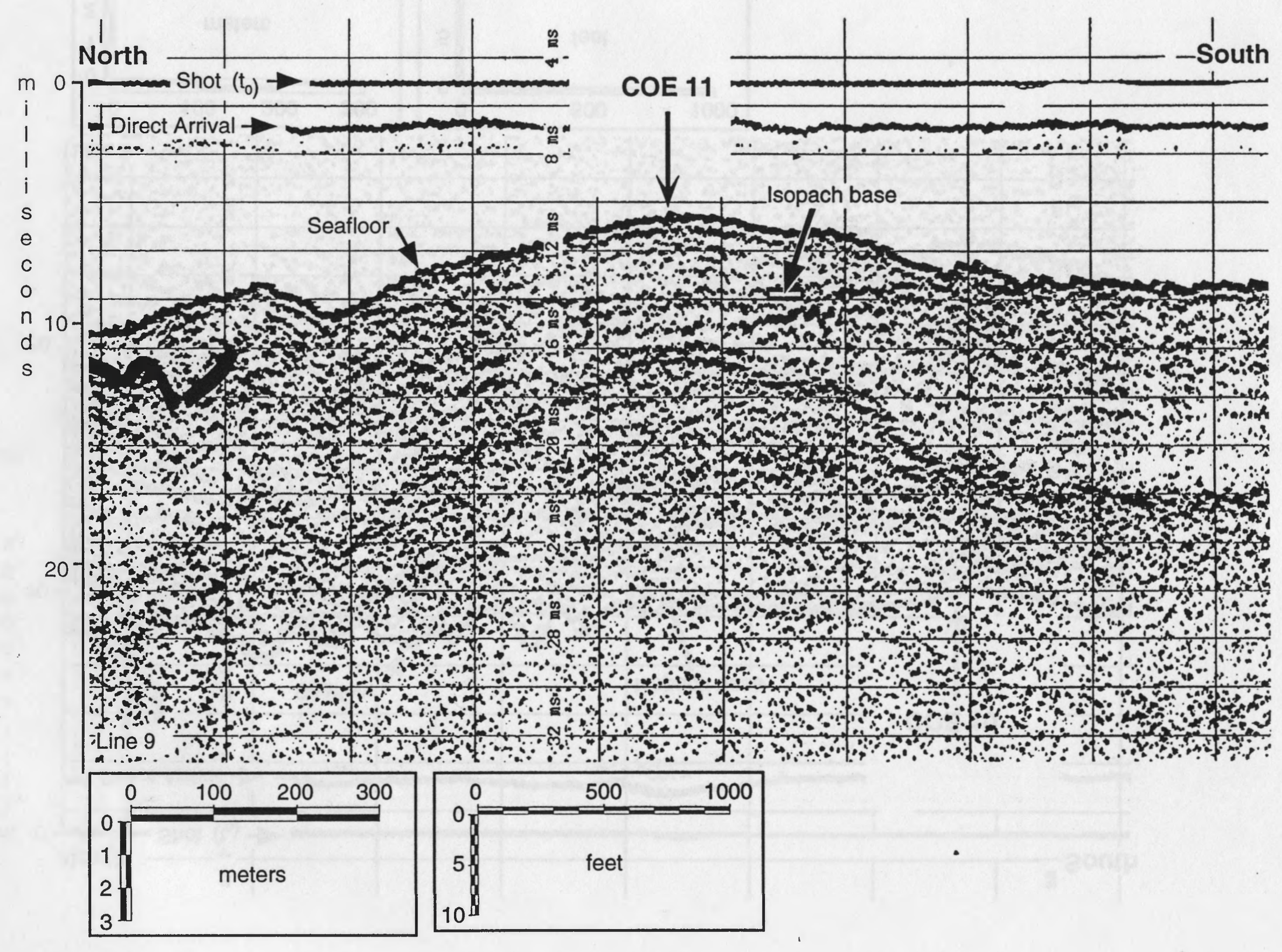




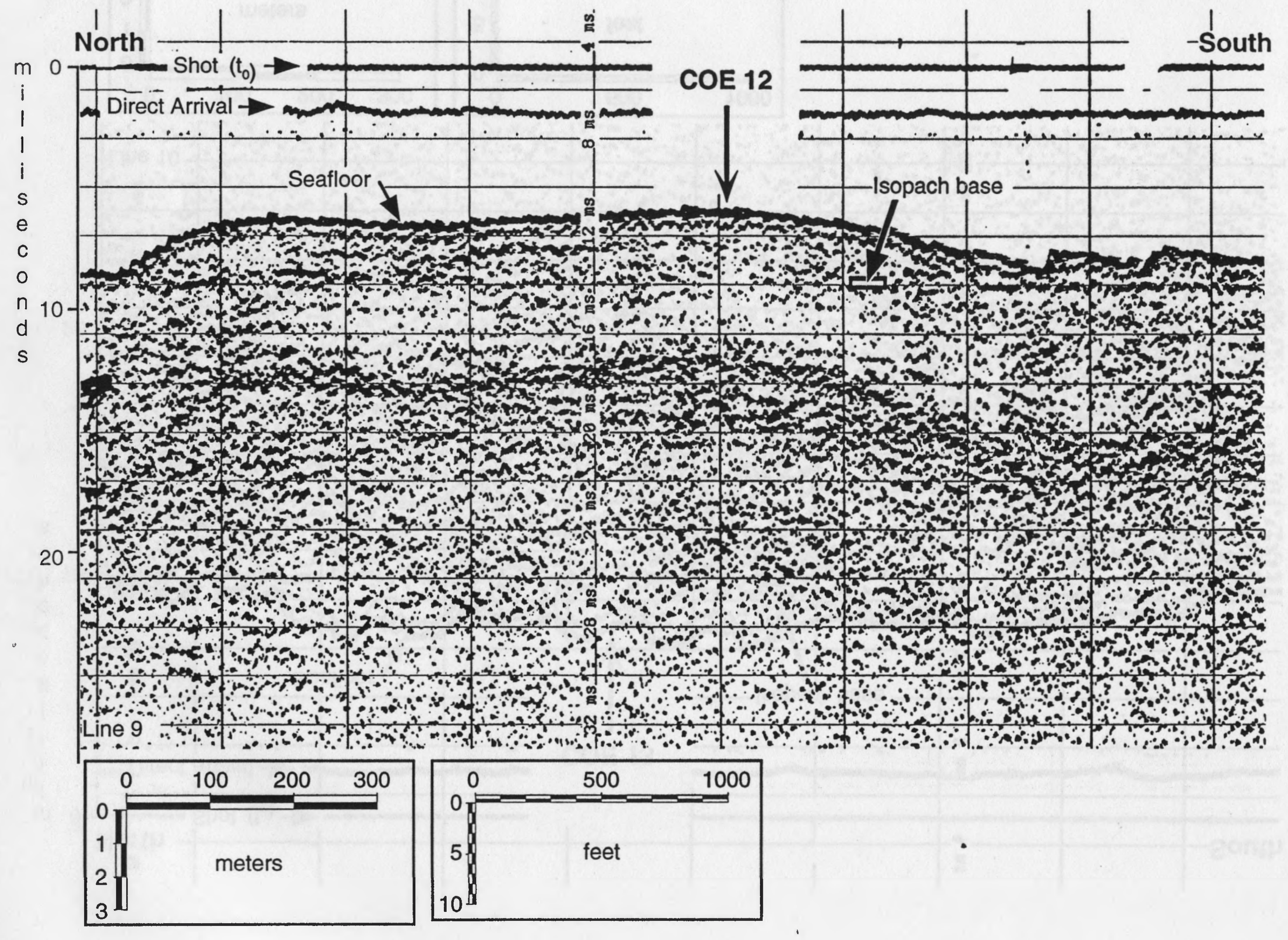




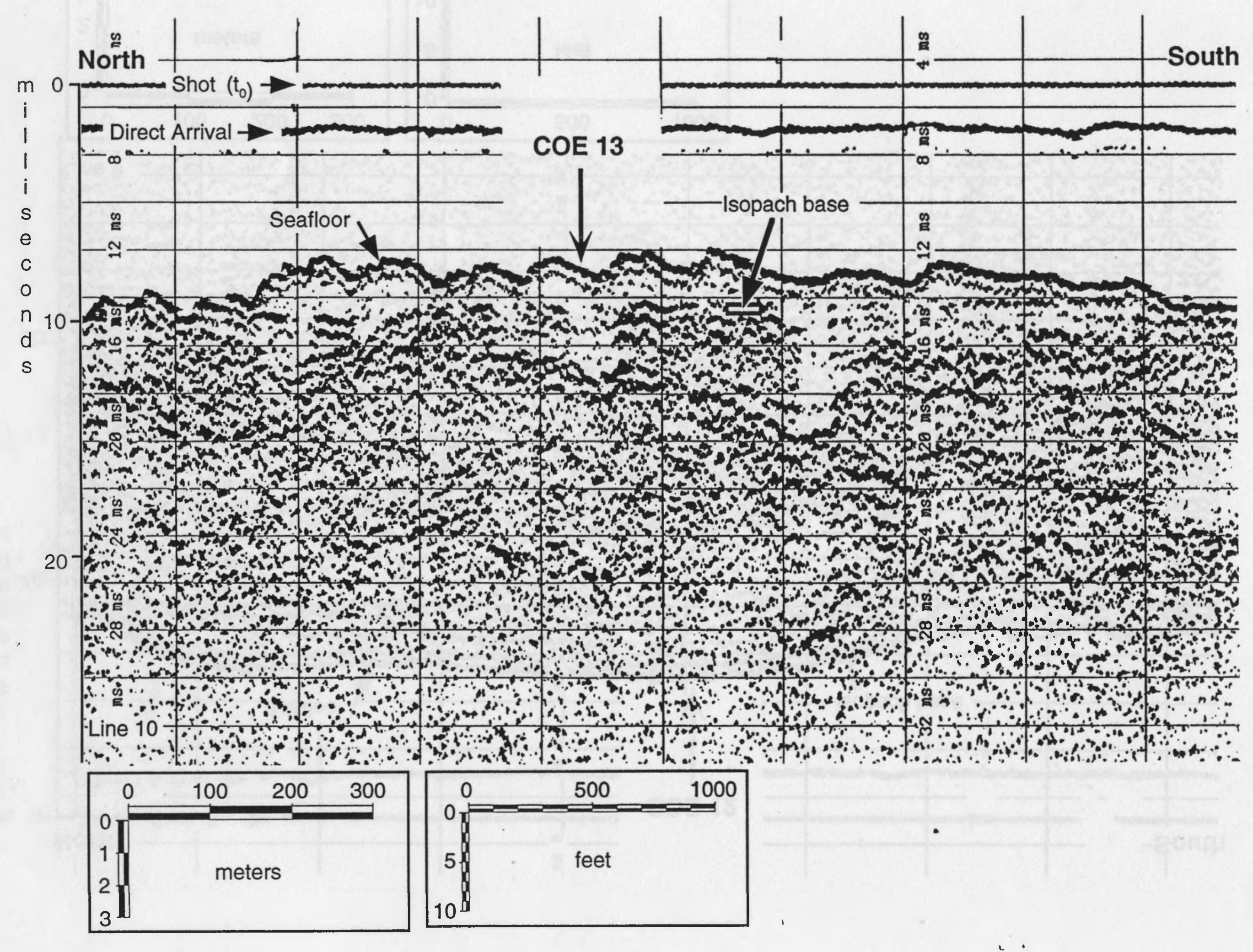



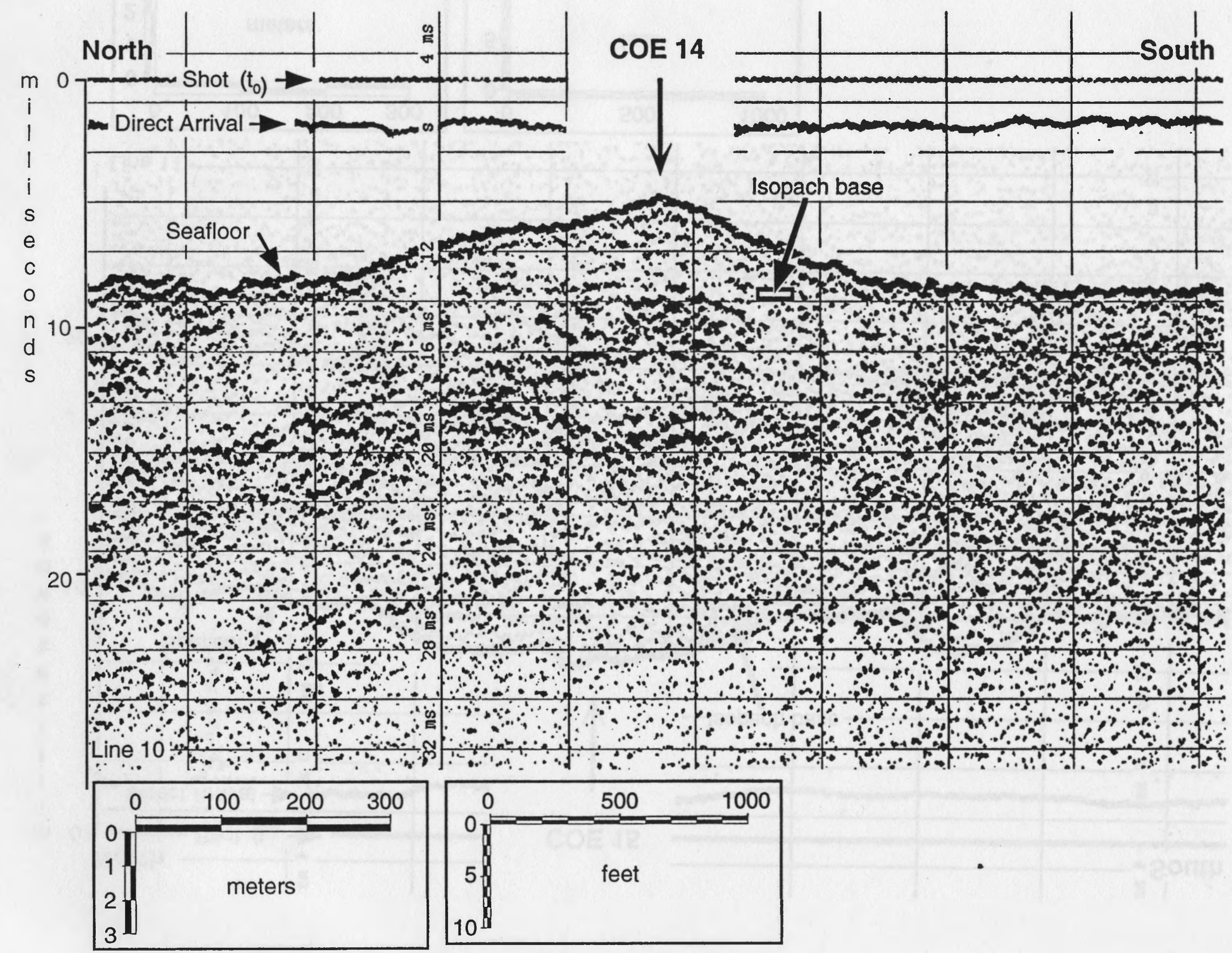


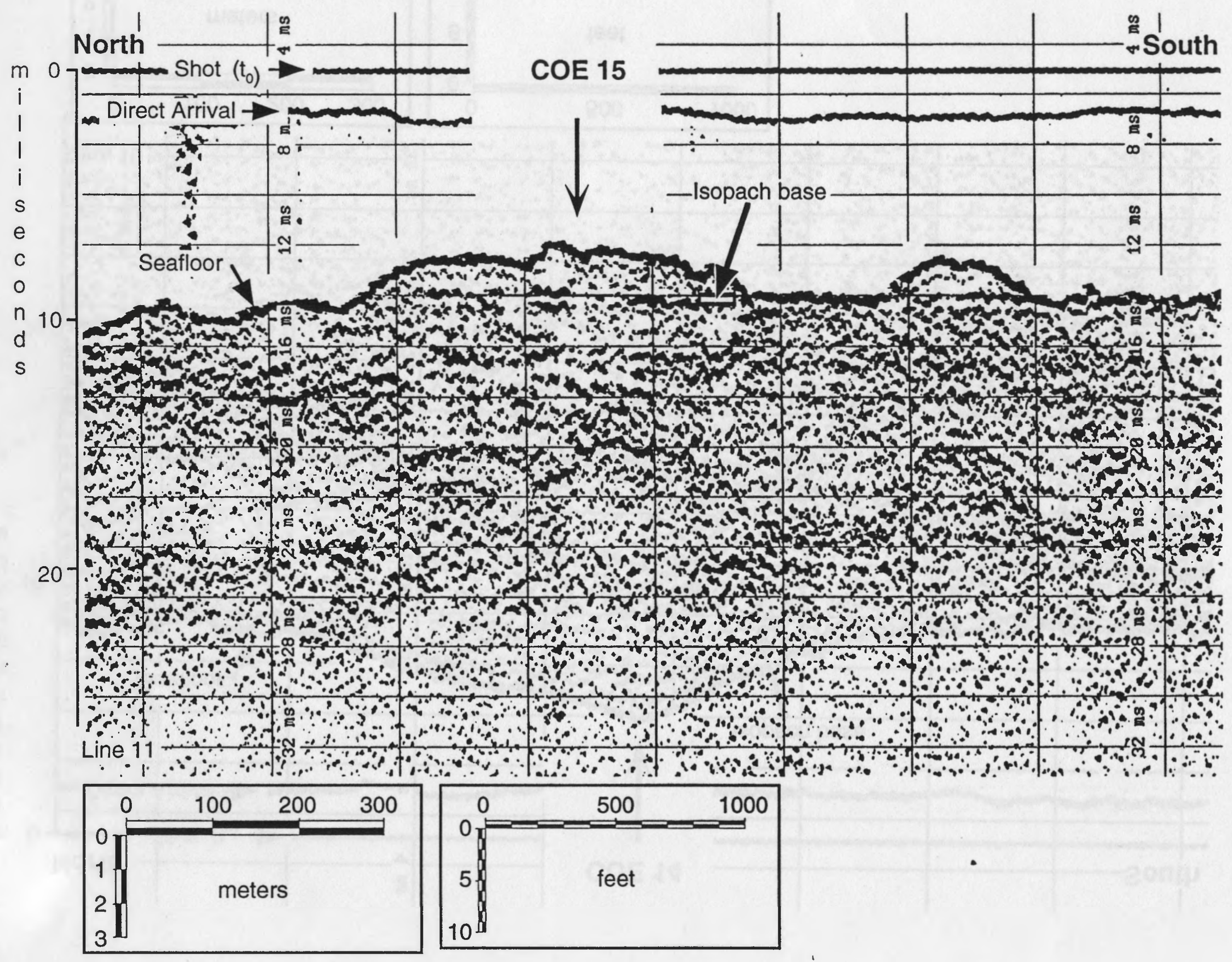




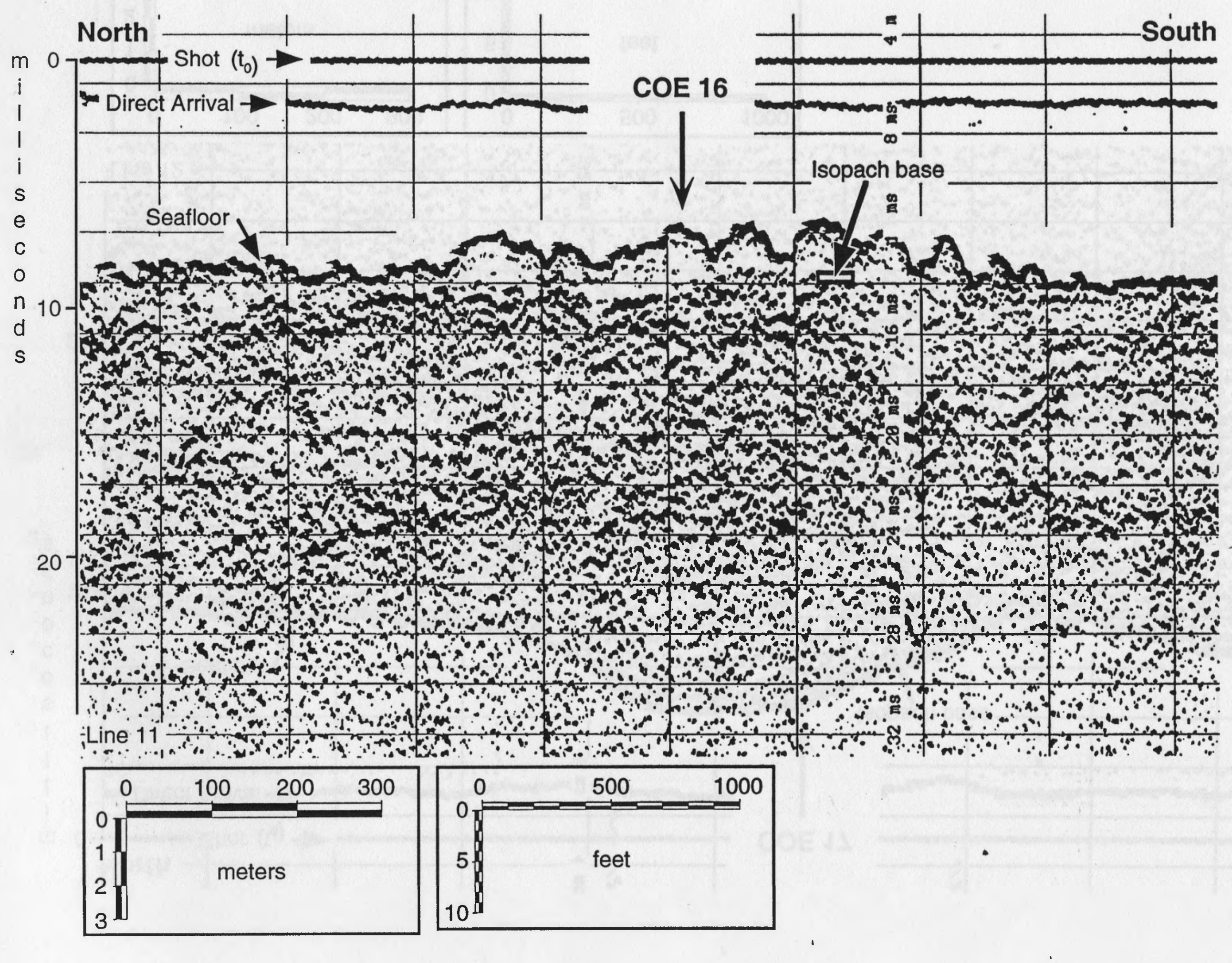




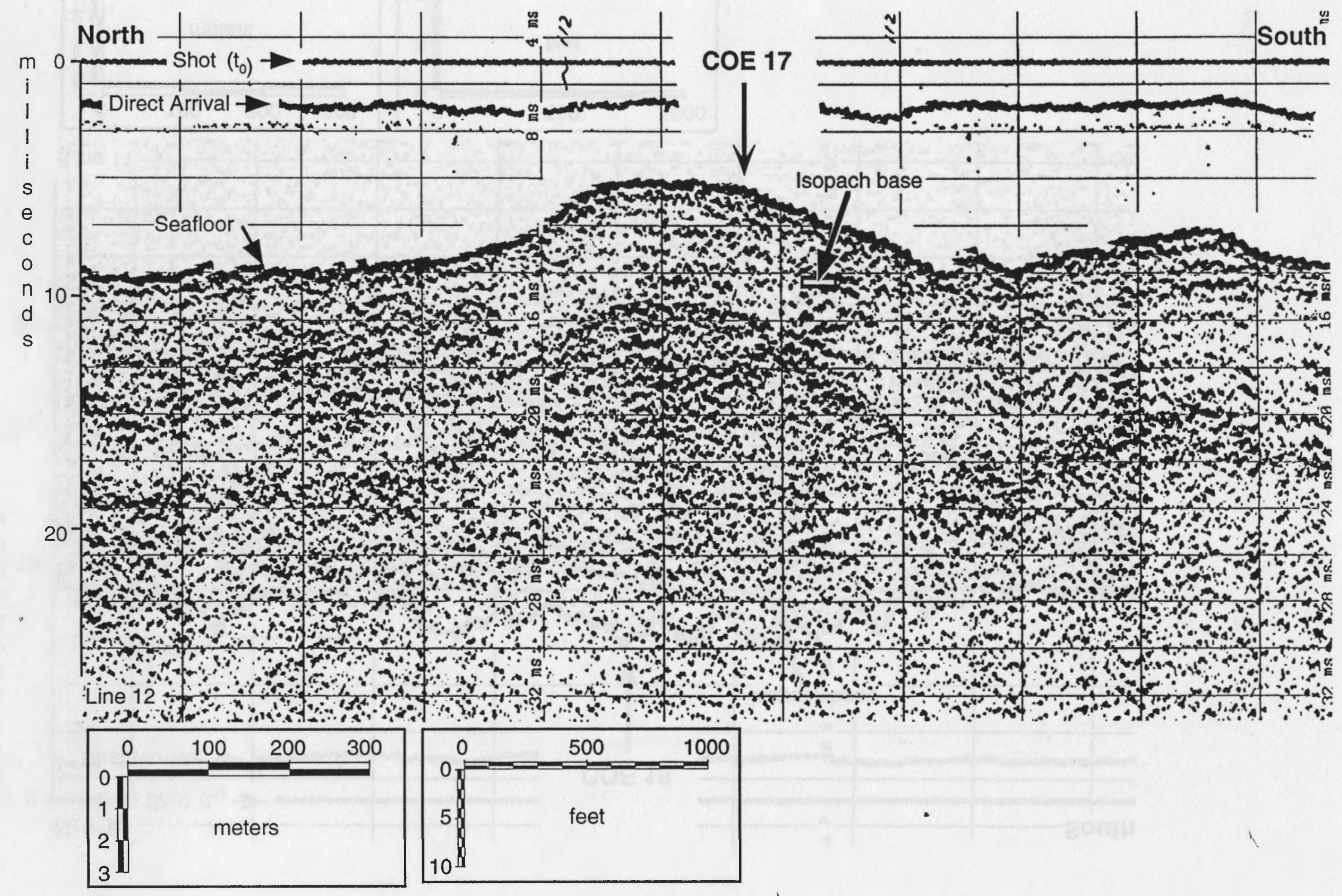




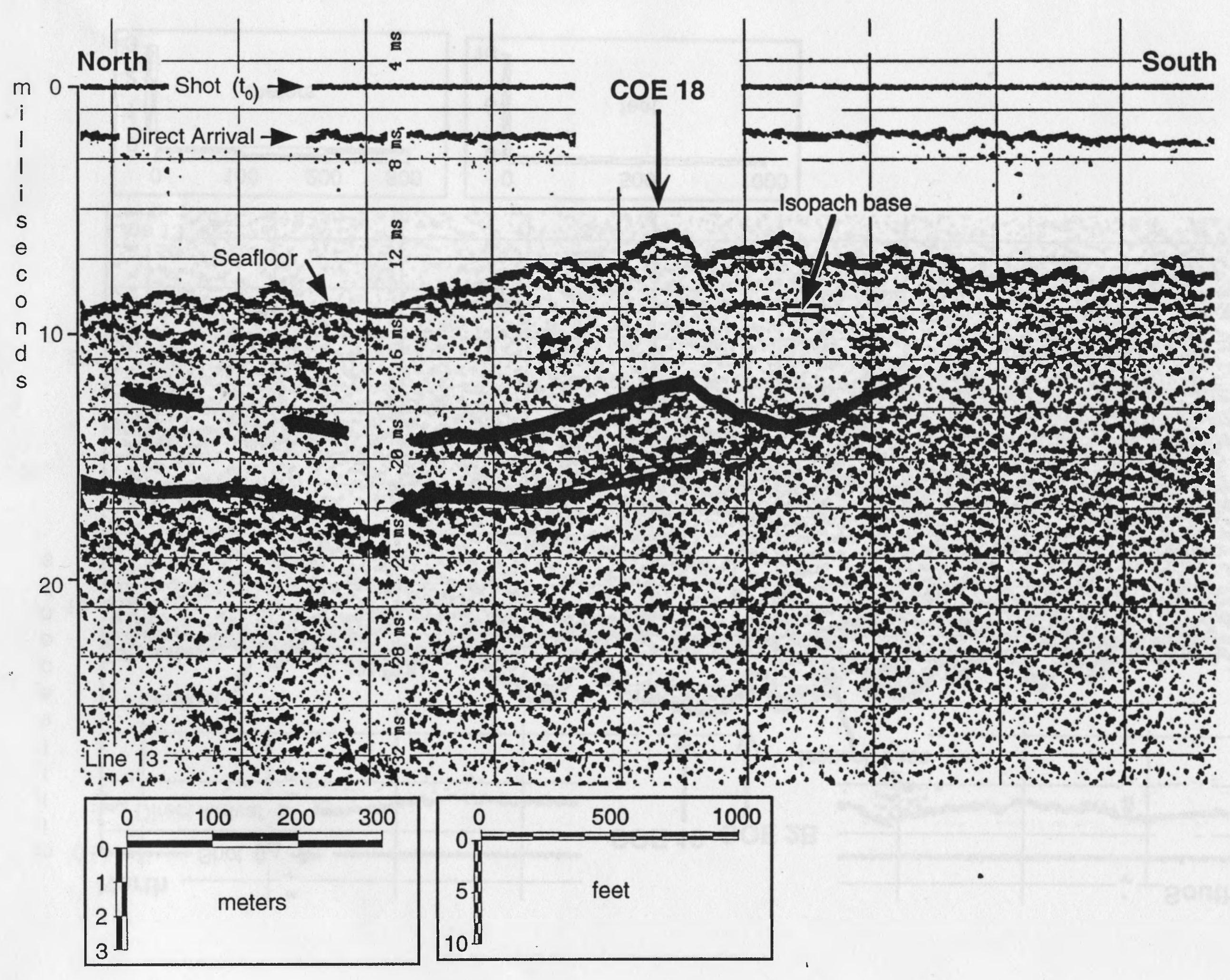



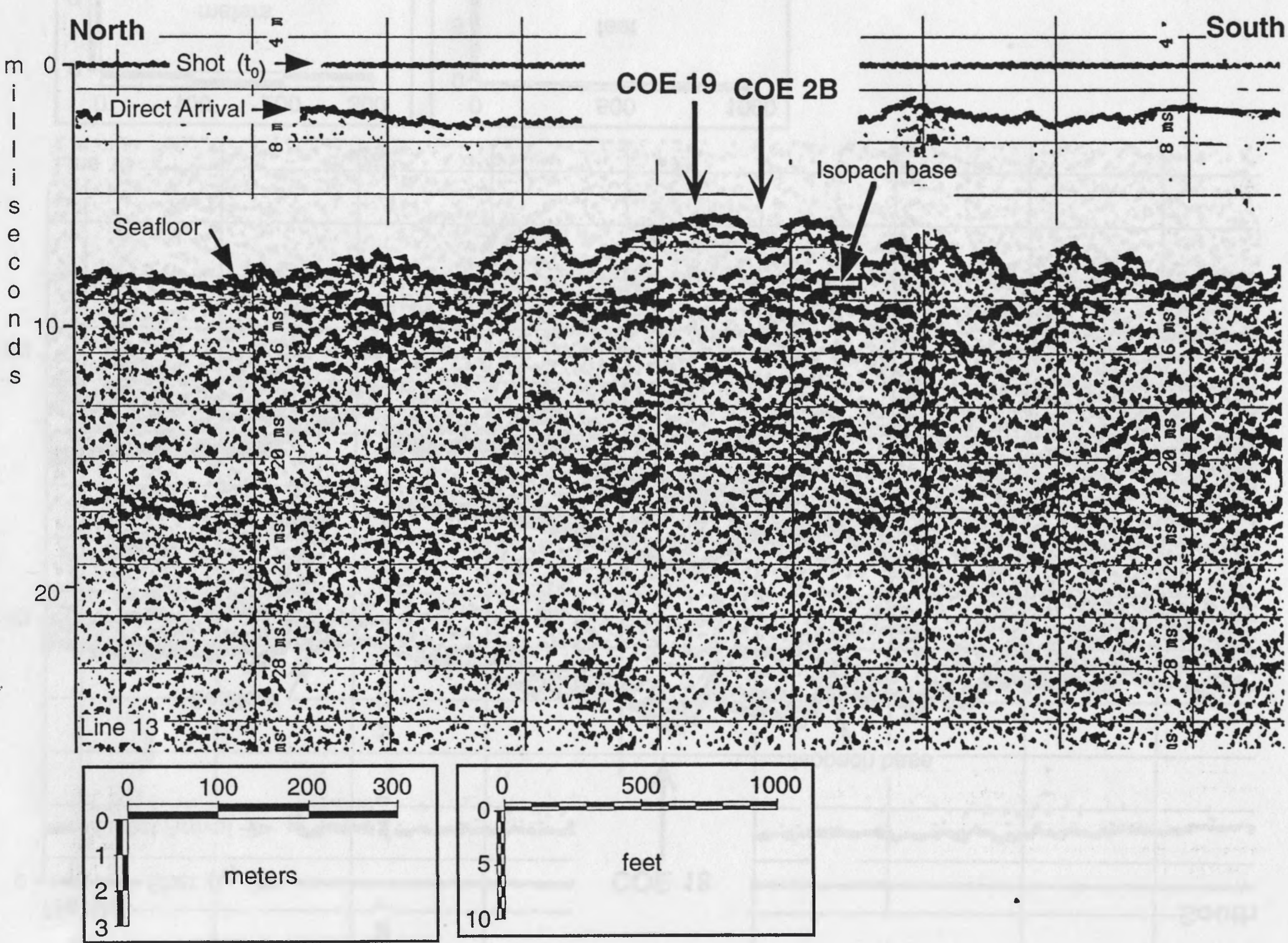

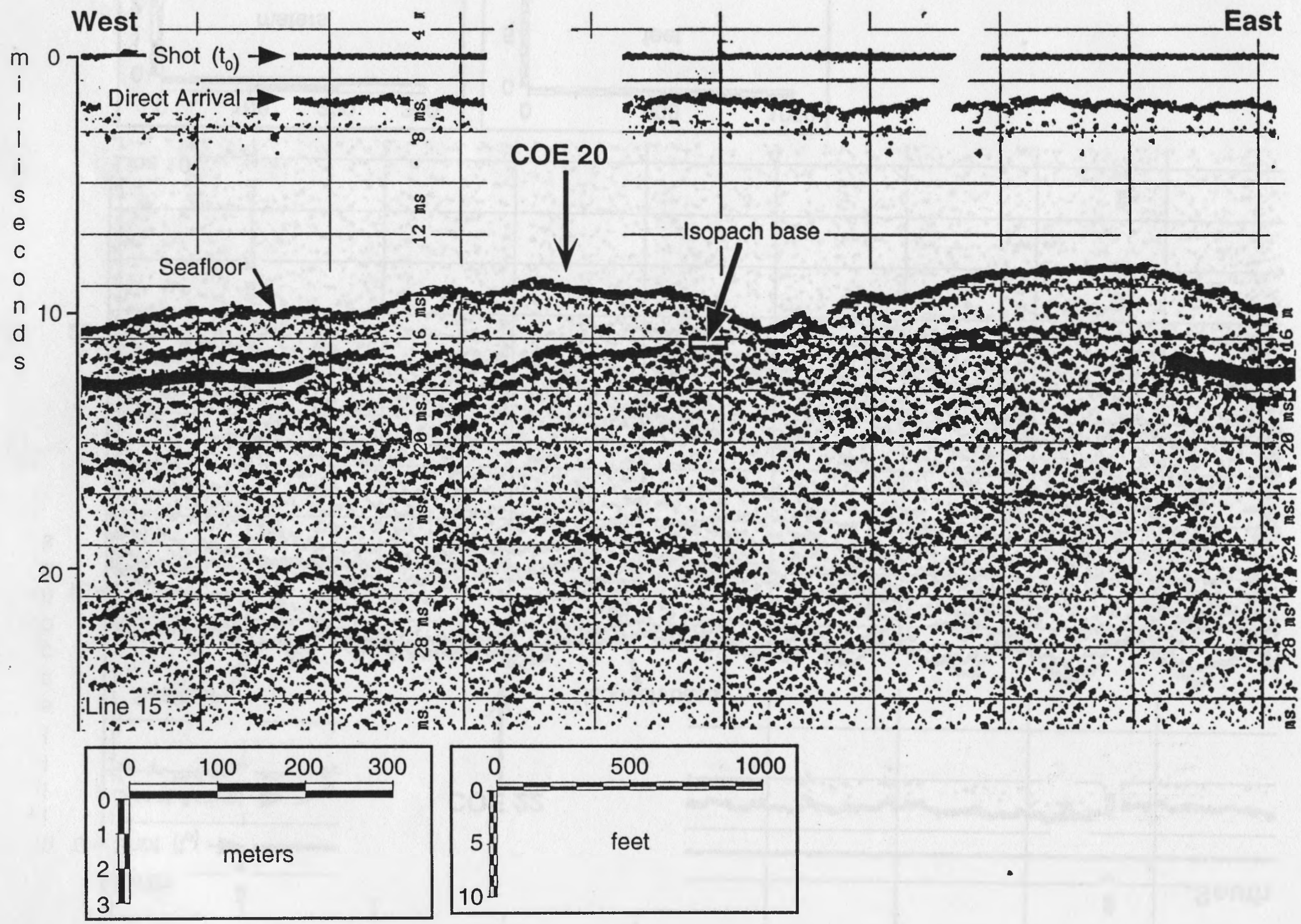


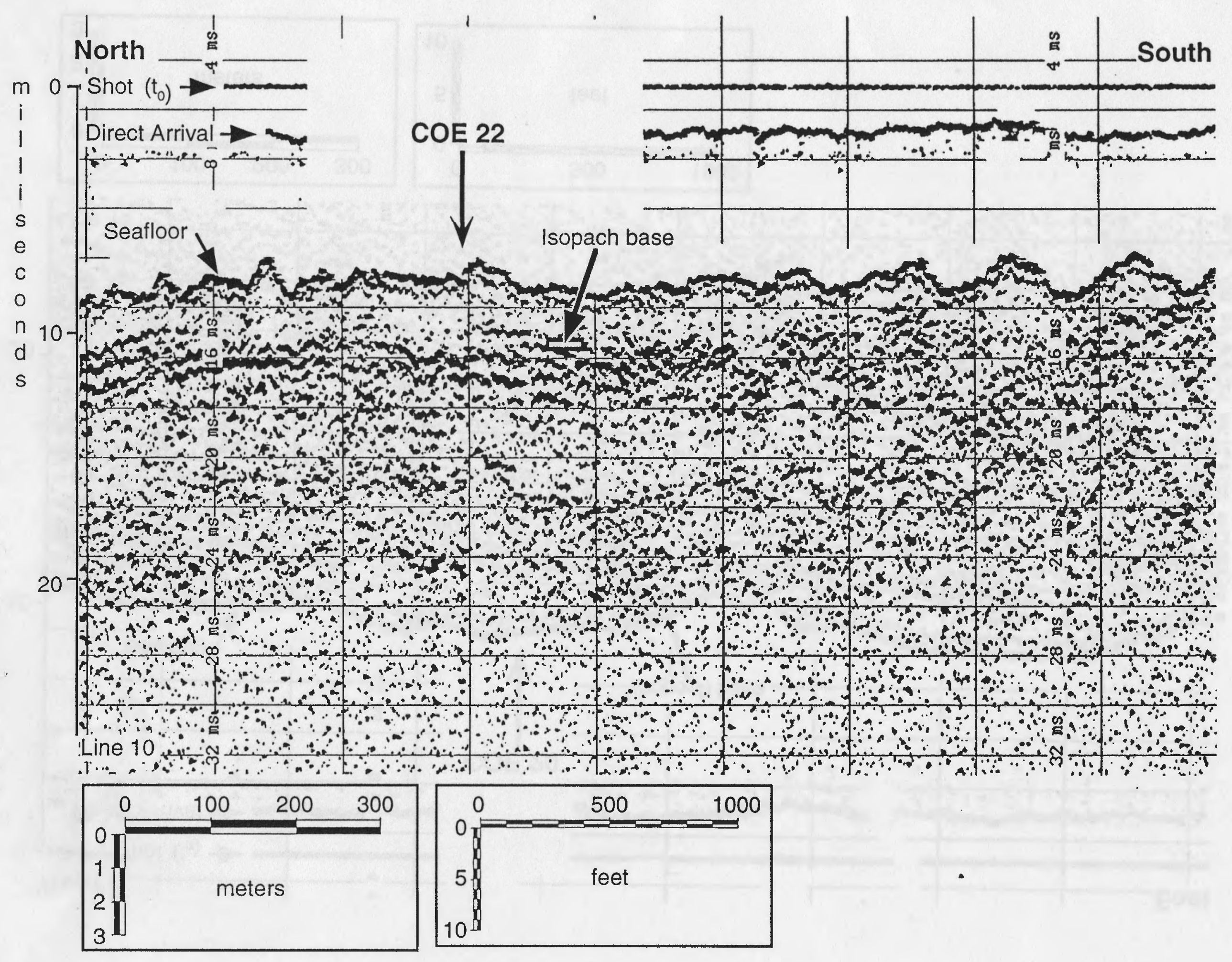


APPENDIX A2

Core Logs 
Hole No.COE-94-1 (2)

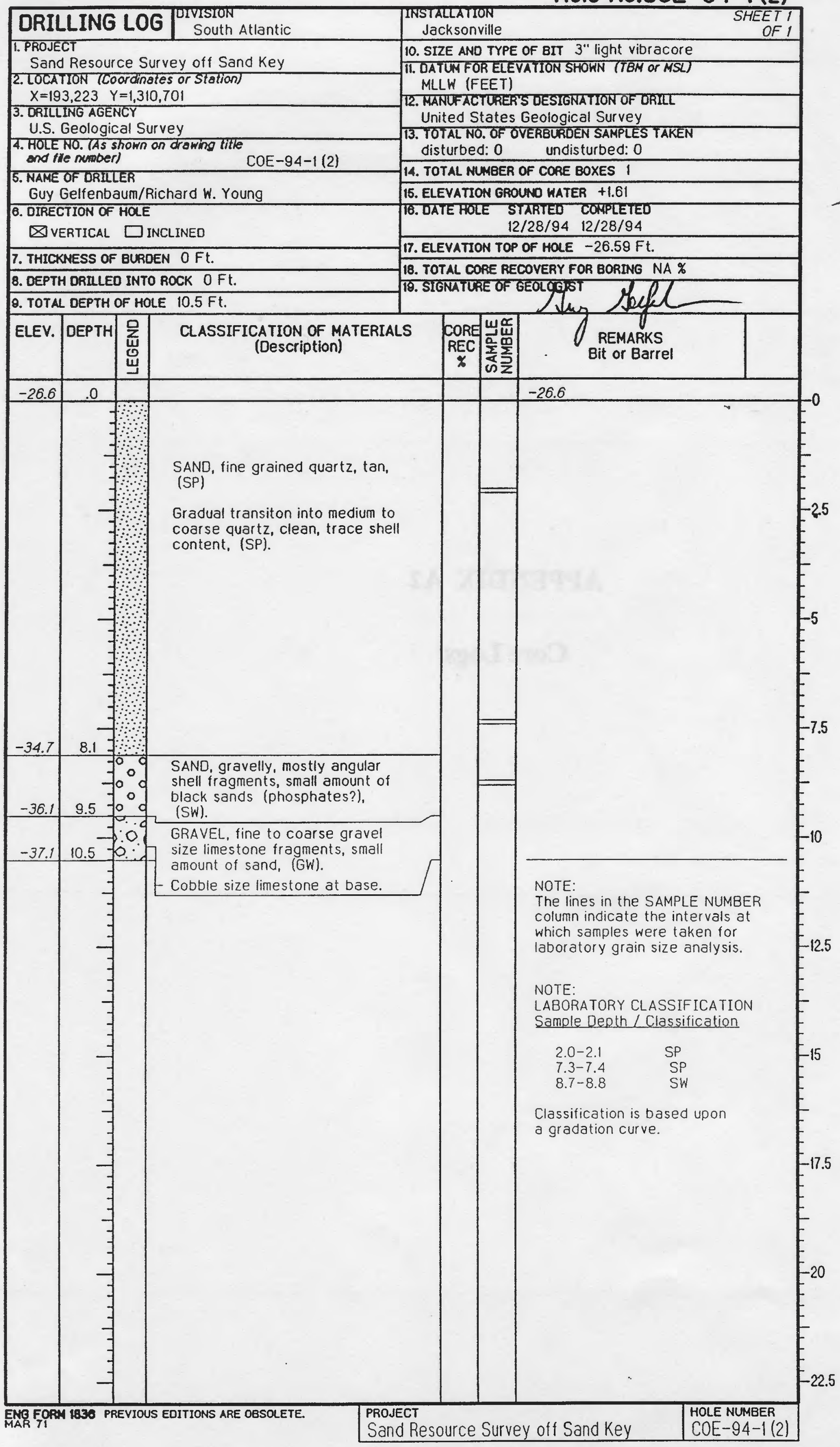


Hole No.COE-94-2 (2)

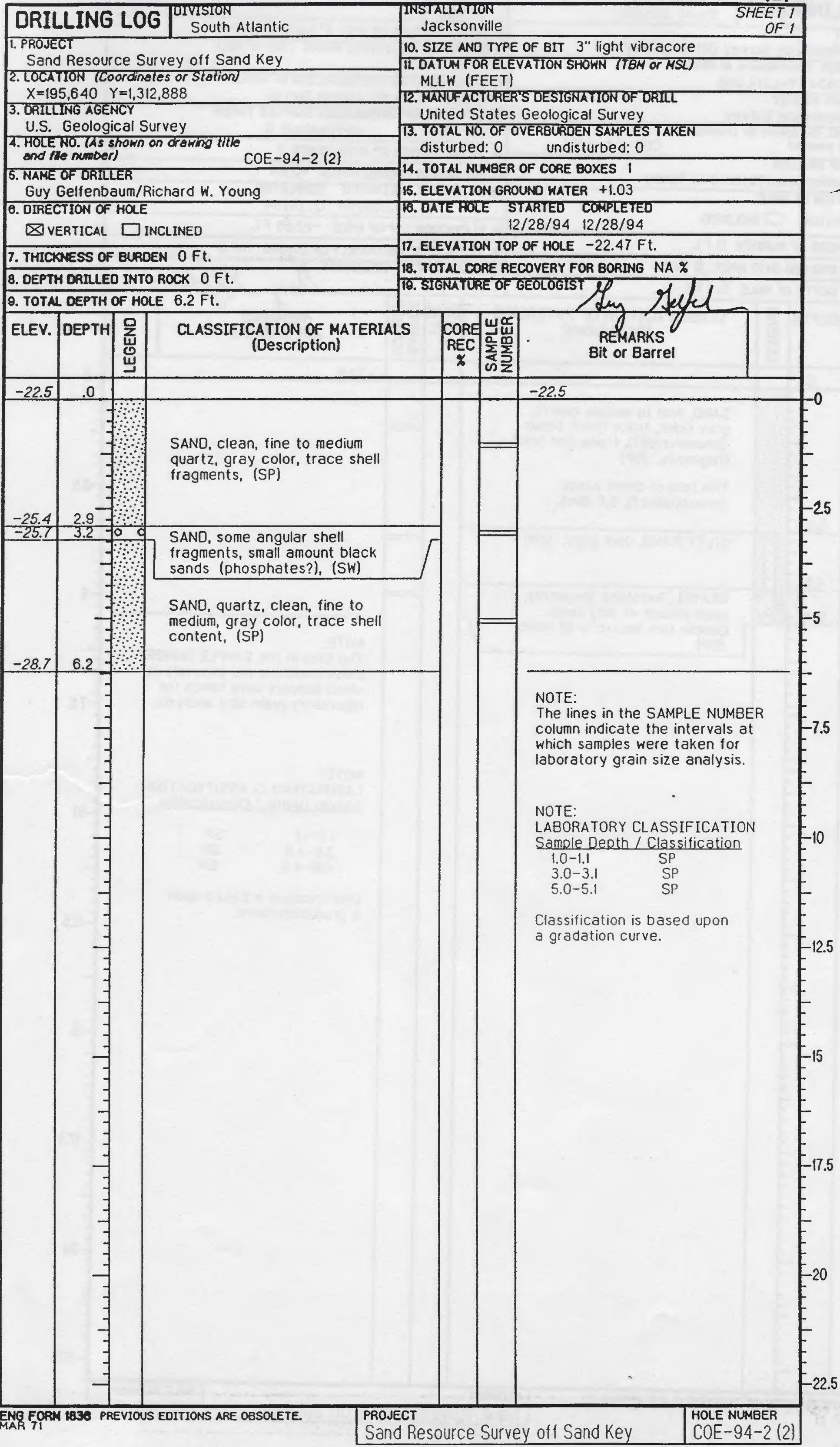


Hole No.COE-94-3 (2)

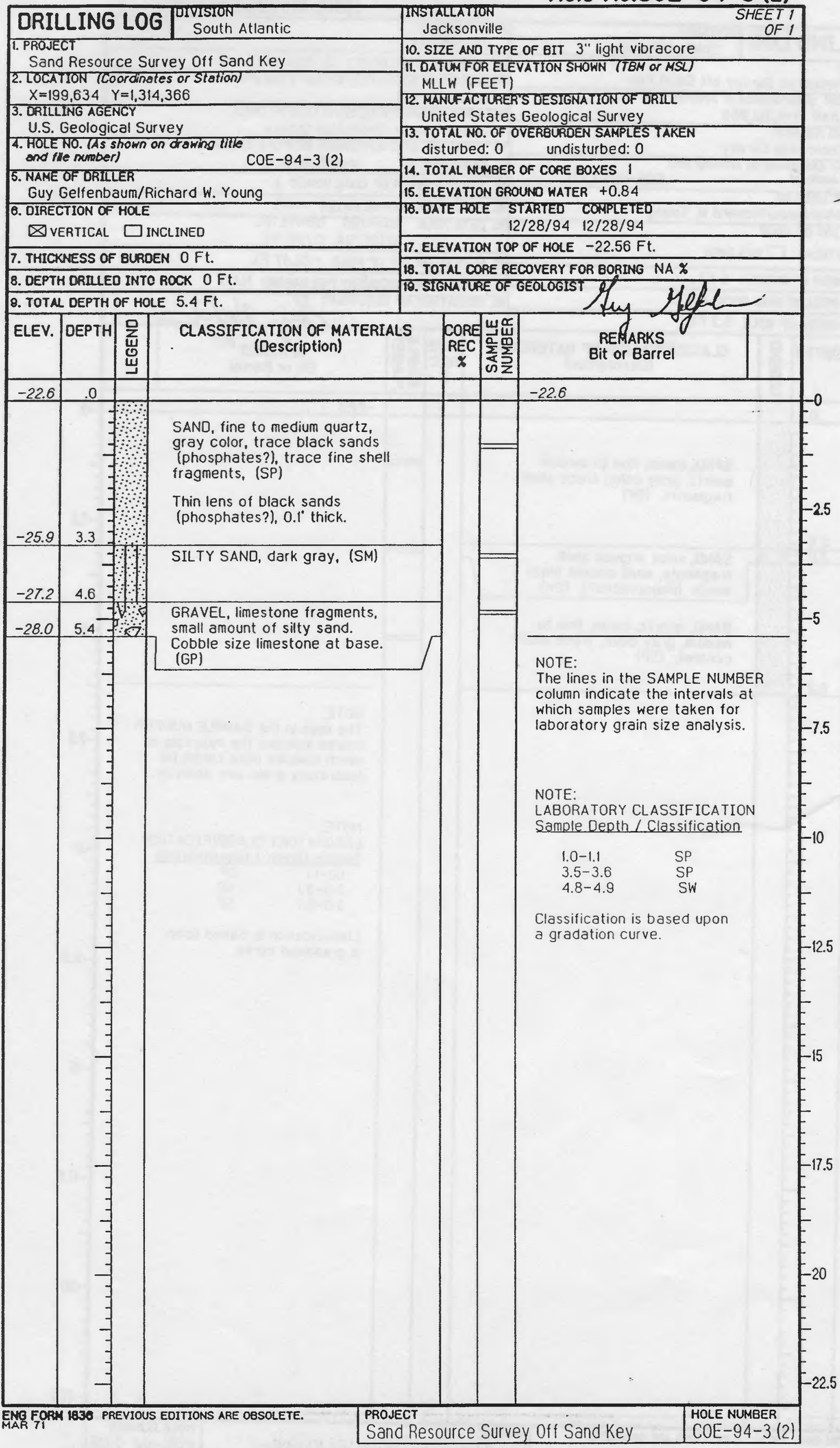


Hole No.COE-94-4 (2)

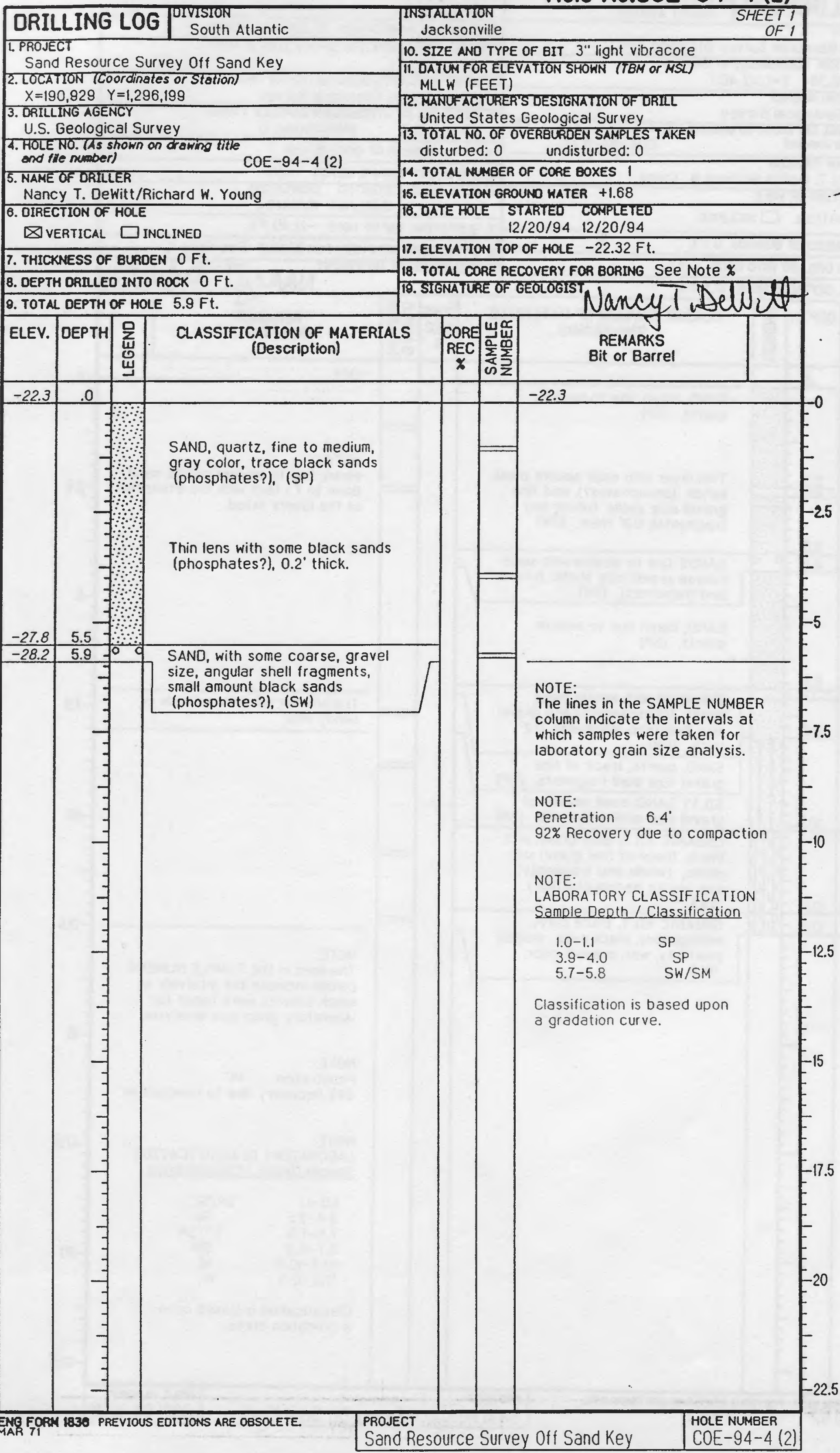




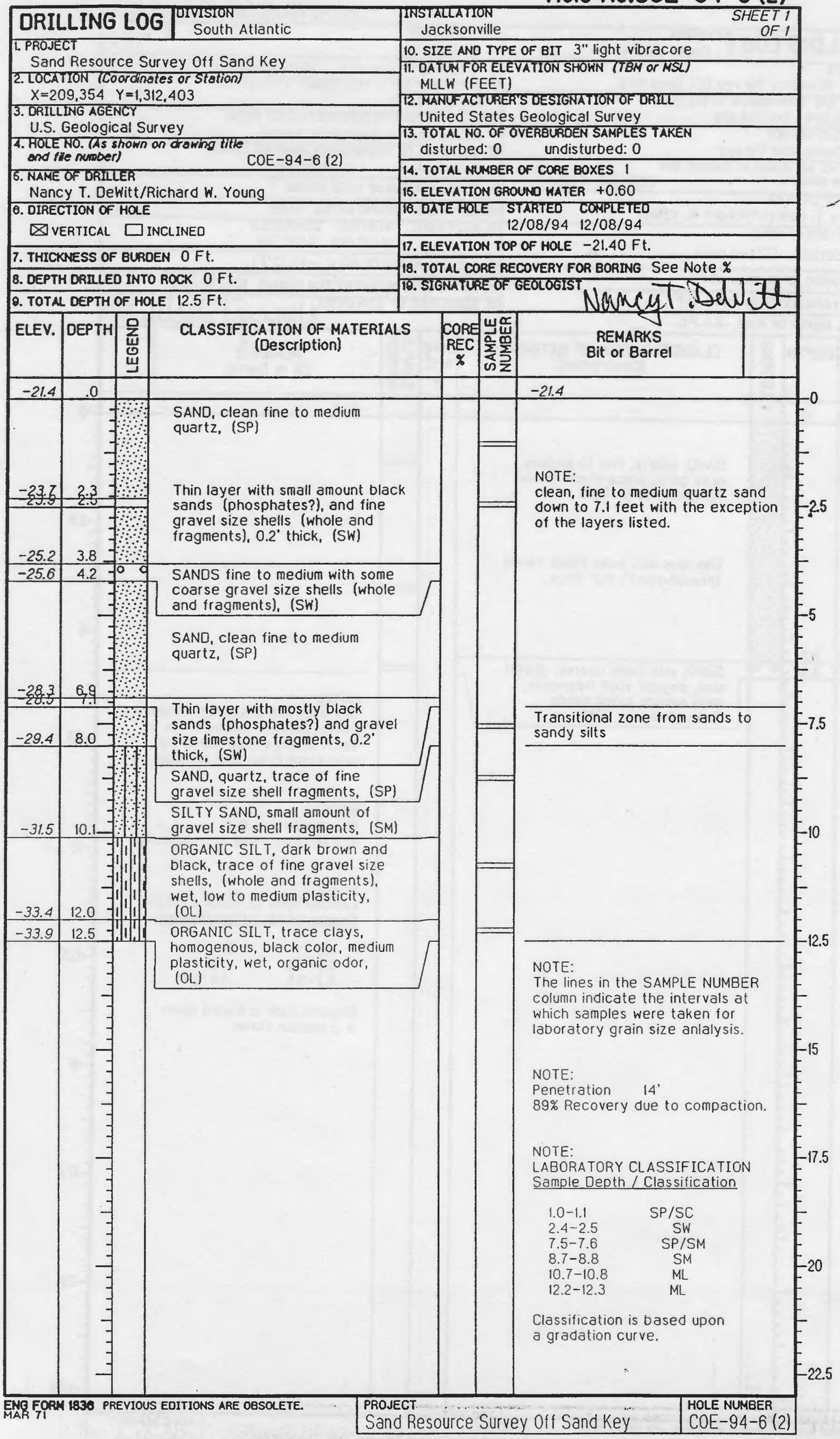




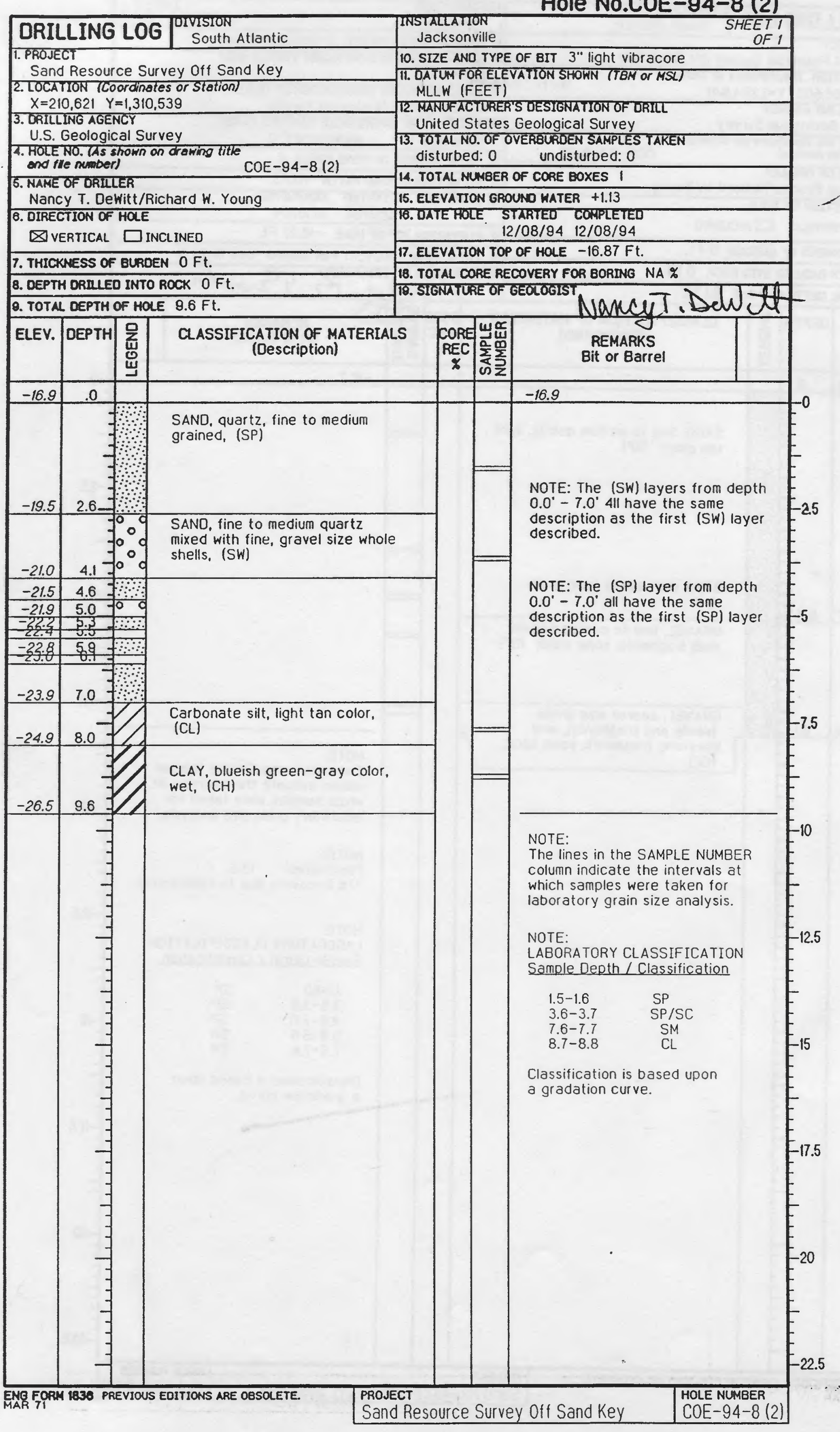




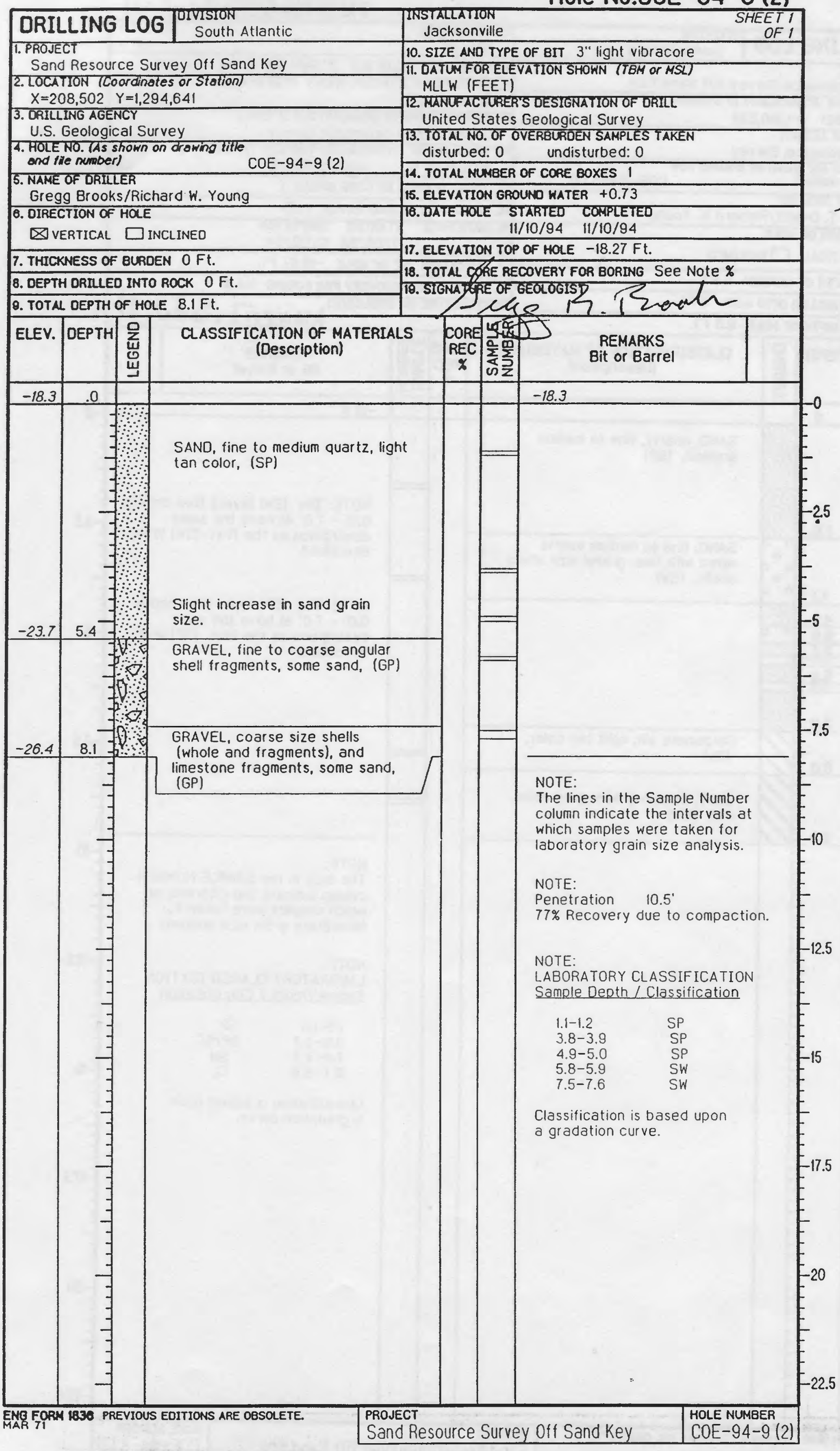




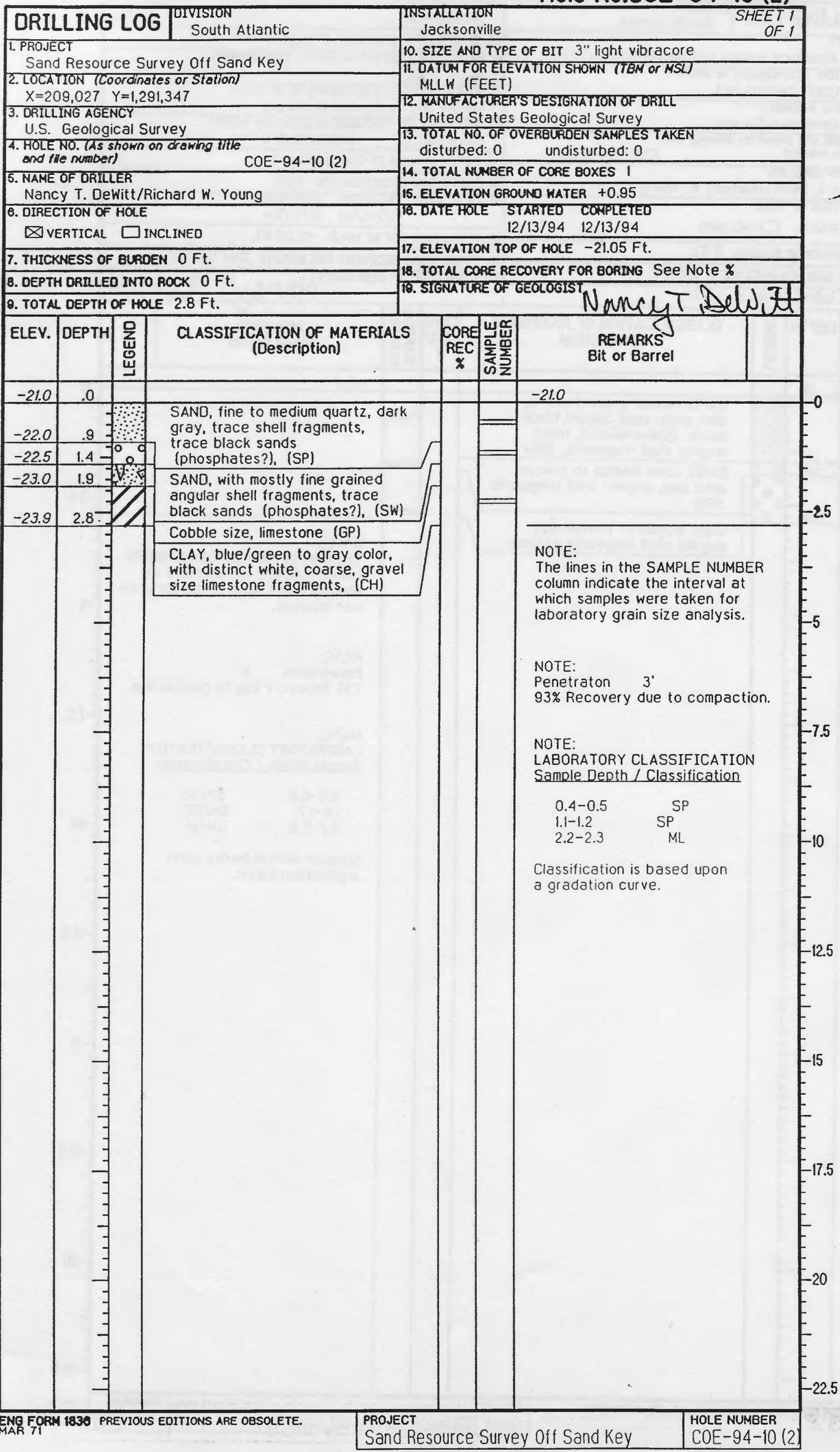


Hole No.COE-94-11 (2)

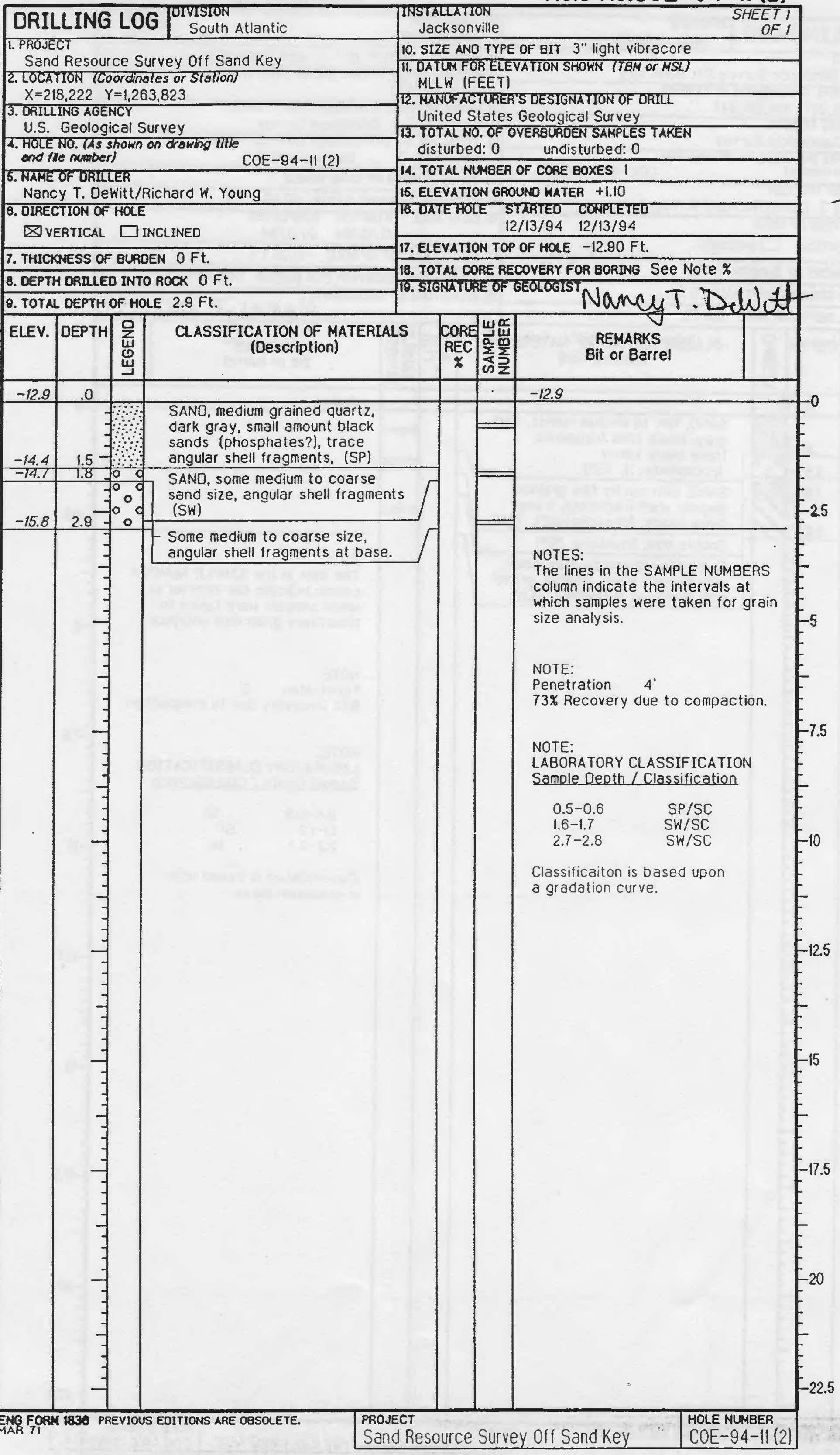




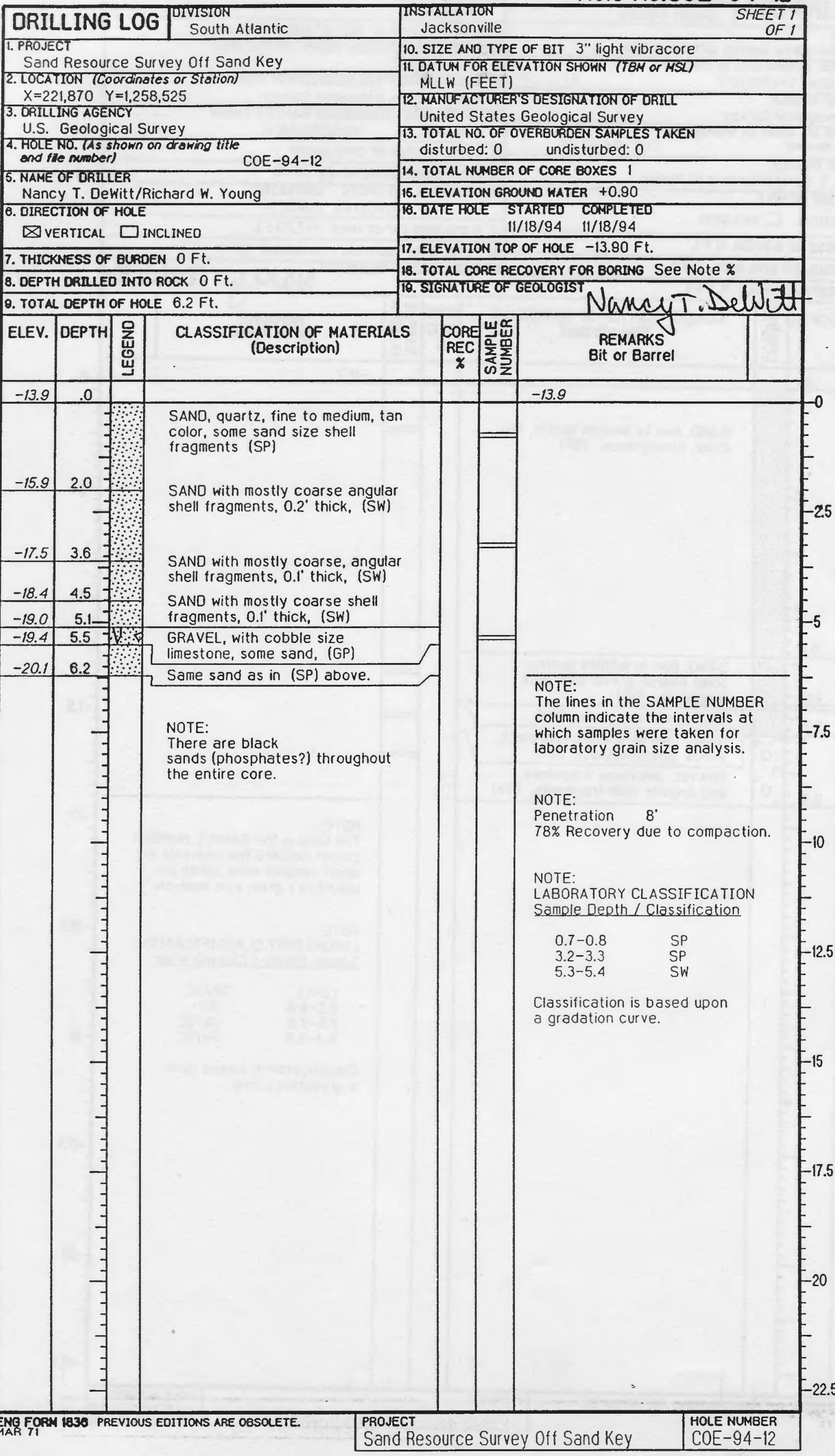


Hole No.COE-94-13 (2)

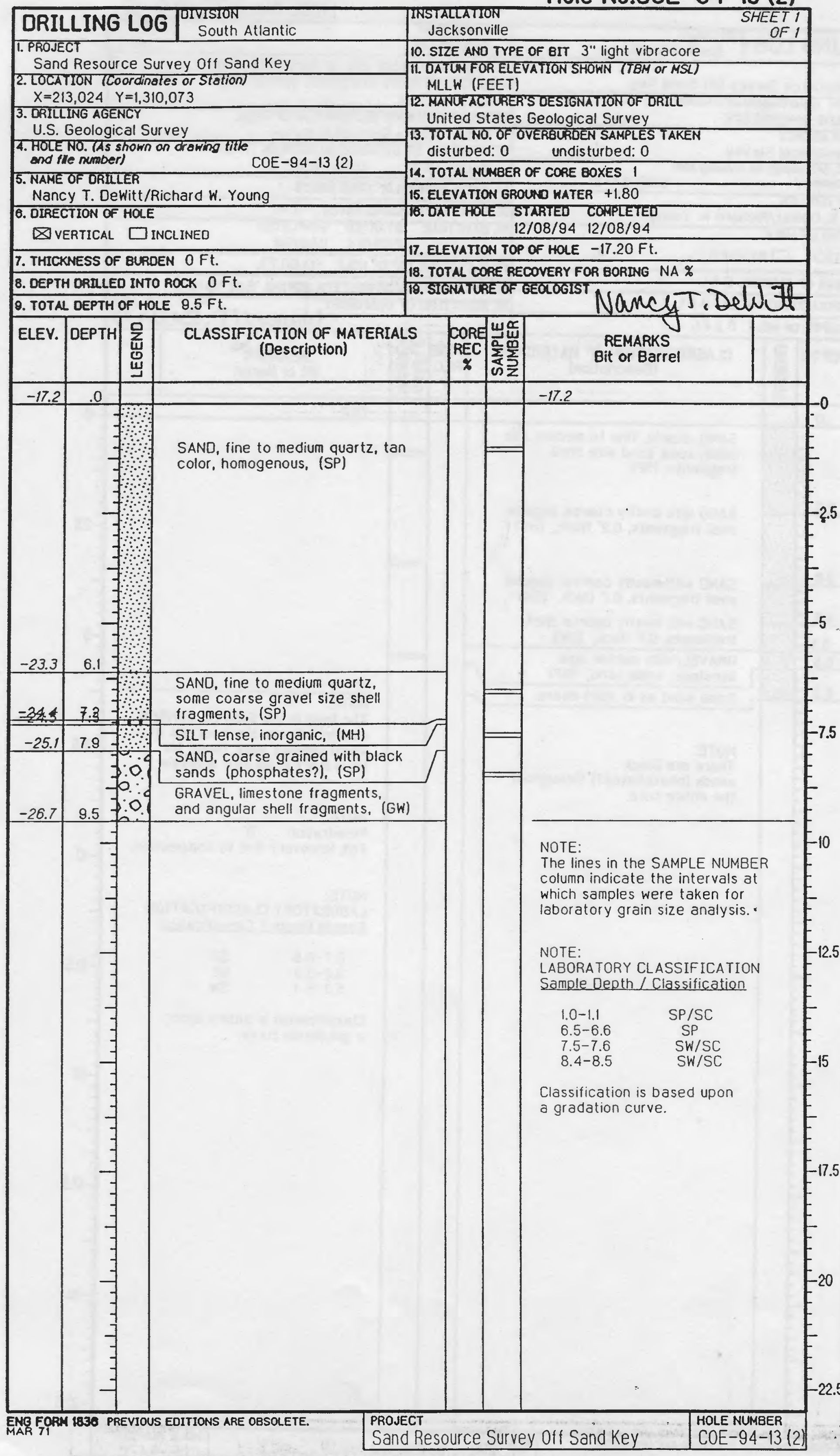




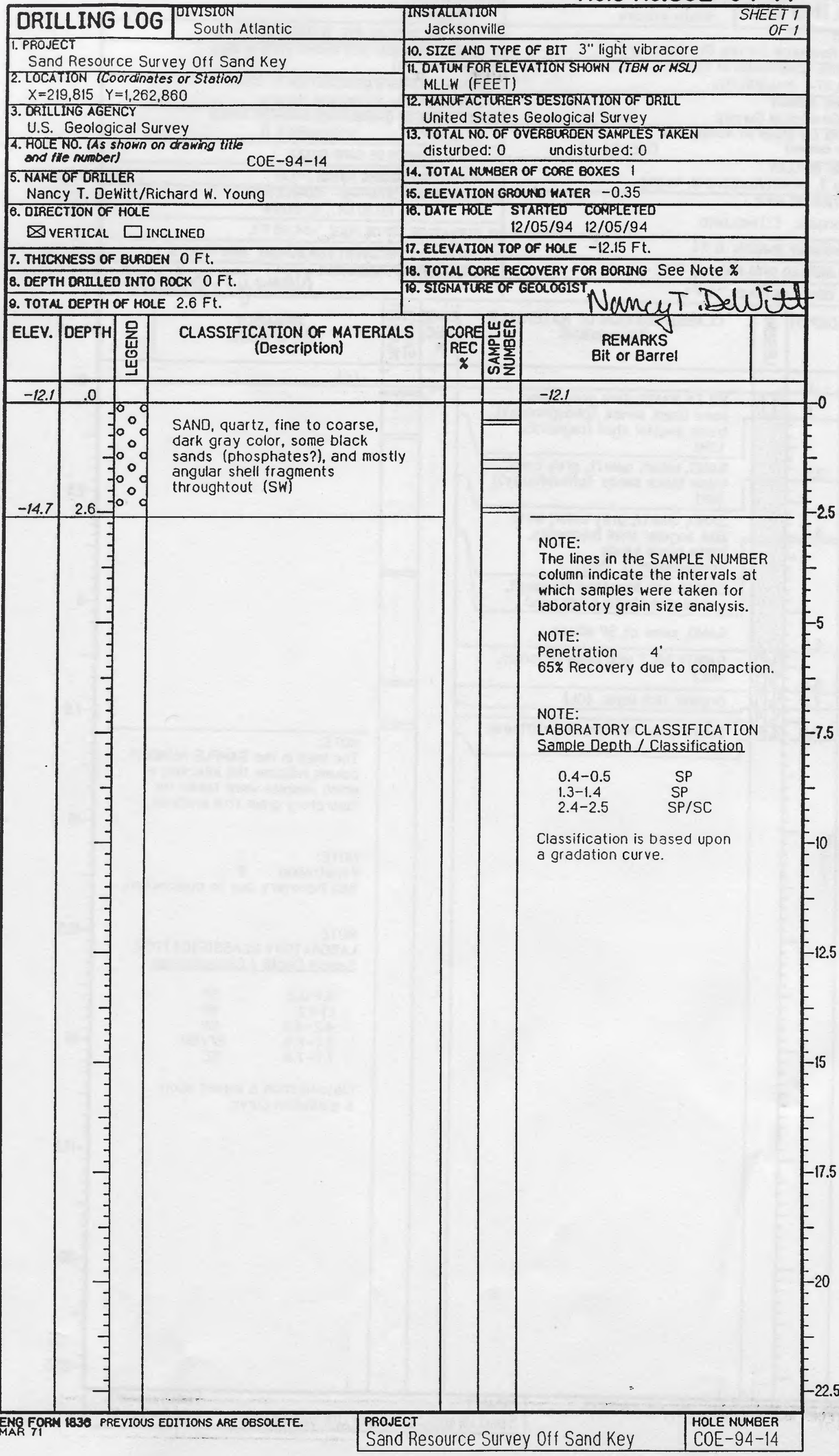




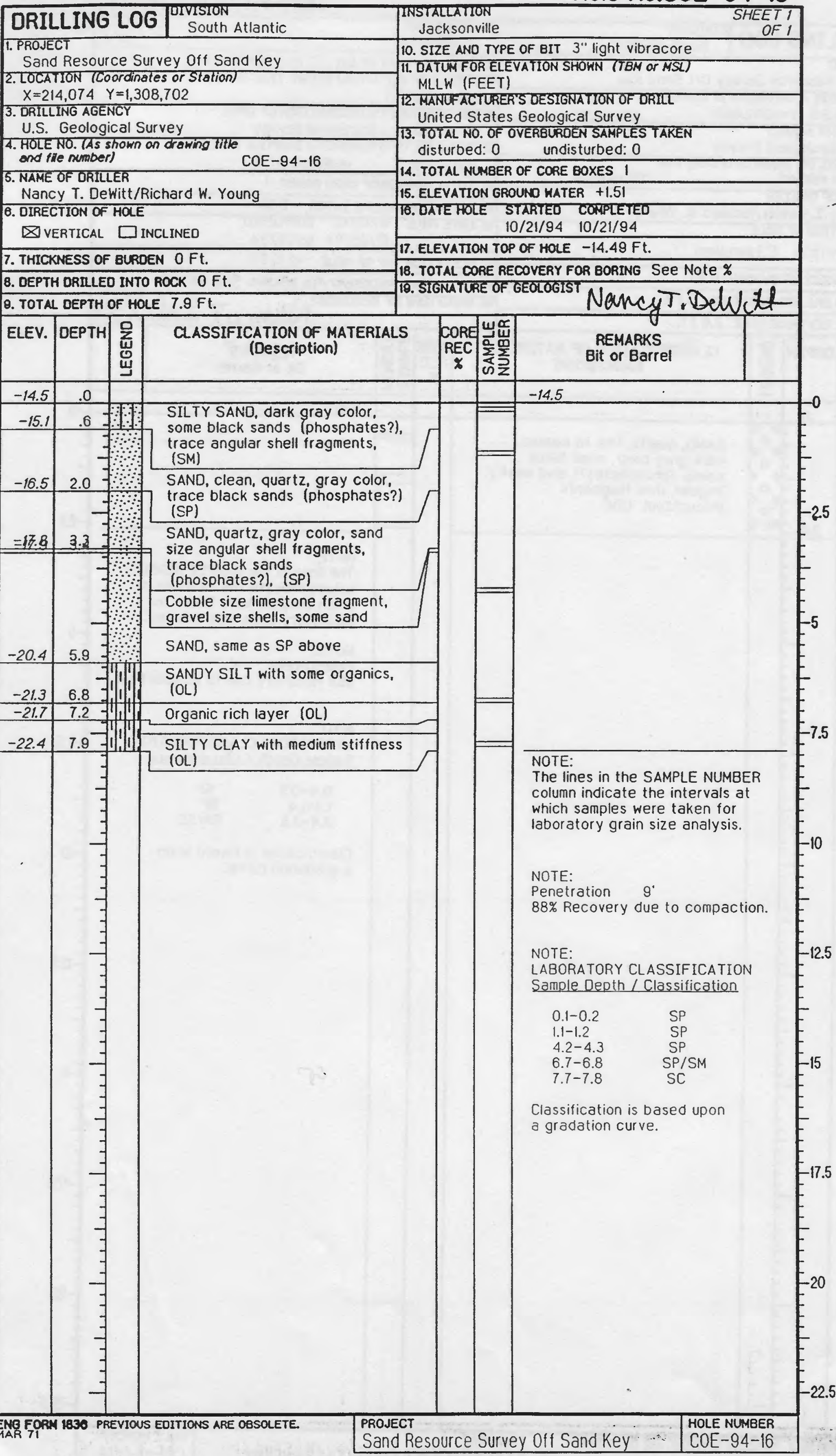


Hole No.COE-94-17 (2)

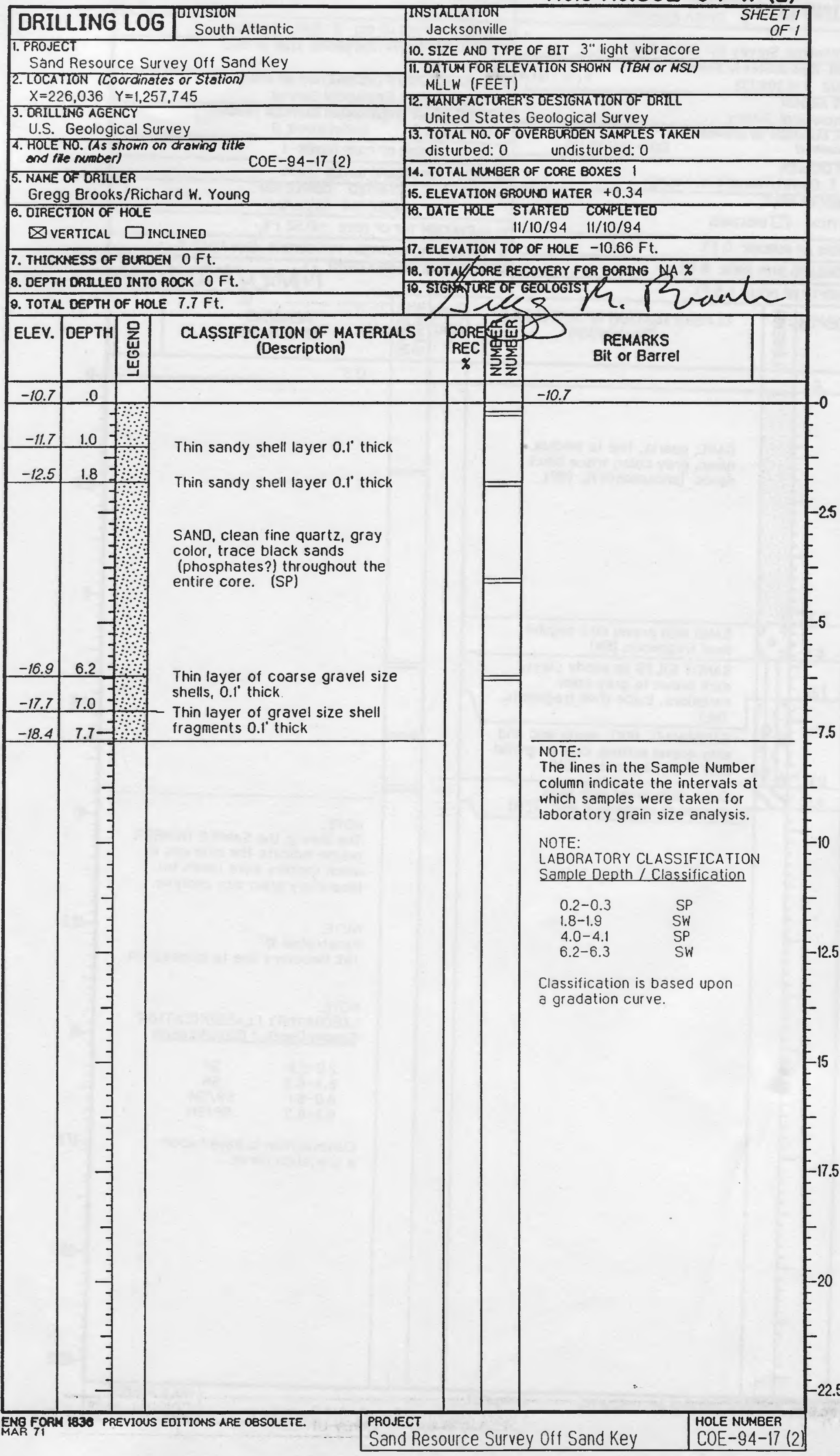




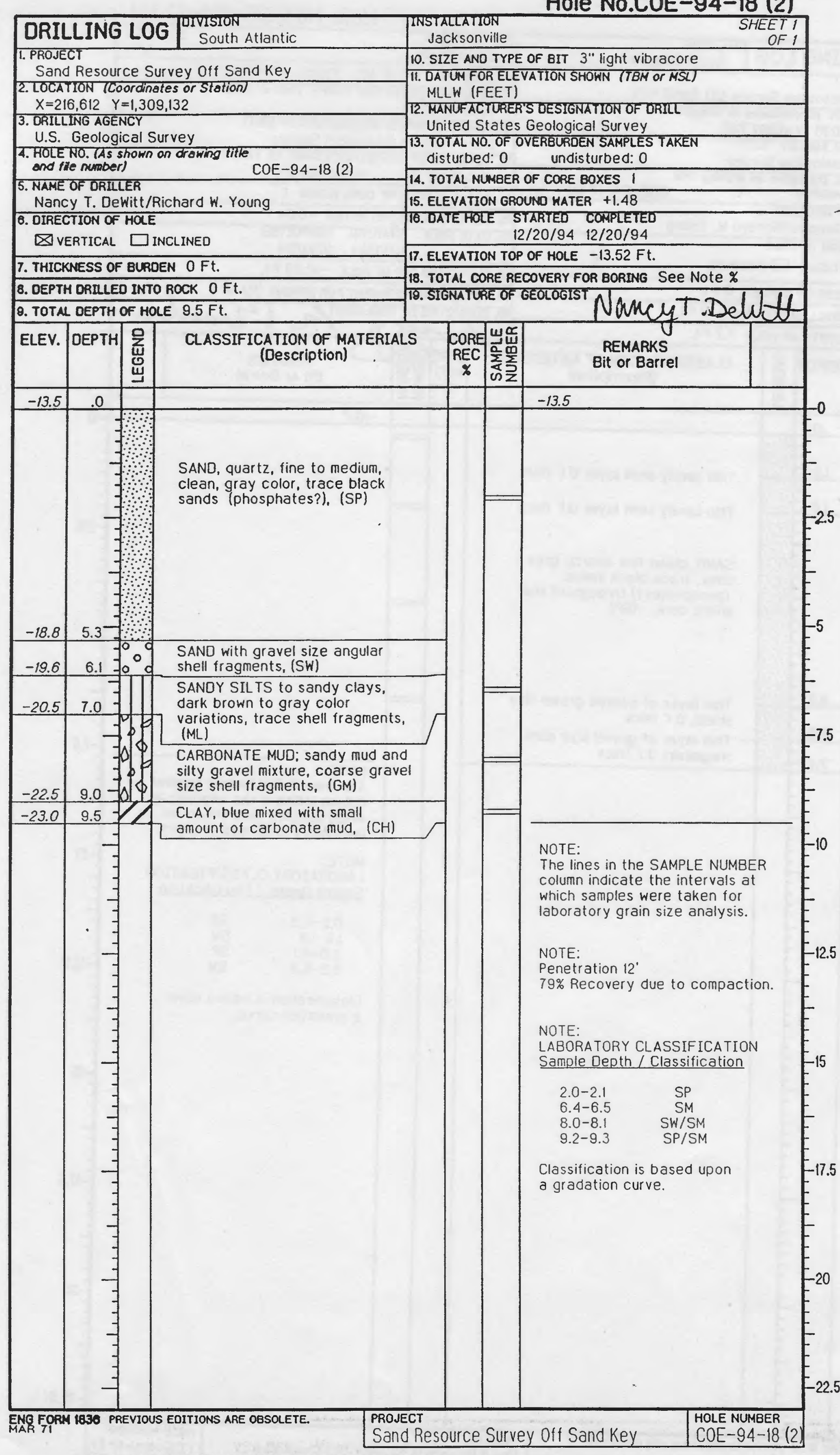


Hole No.COE-94-22

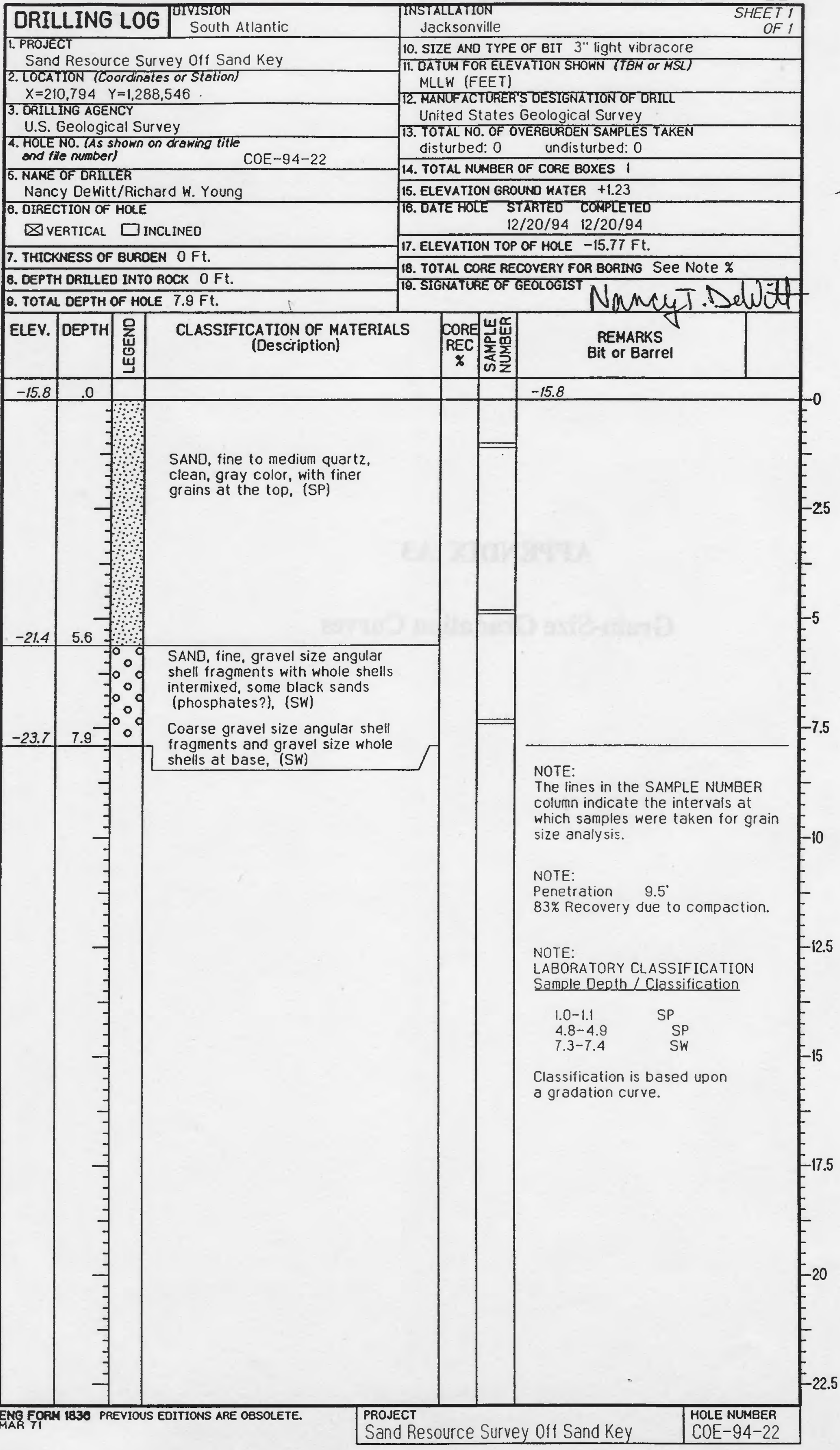




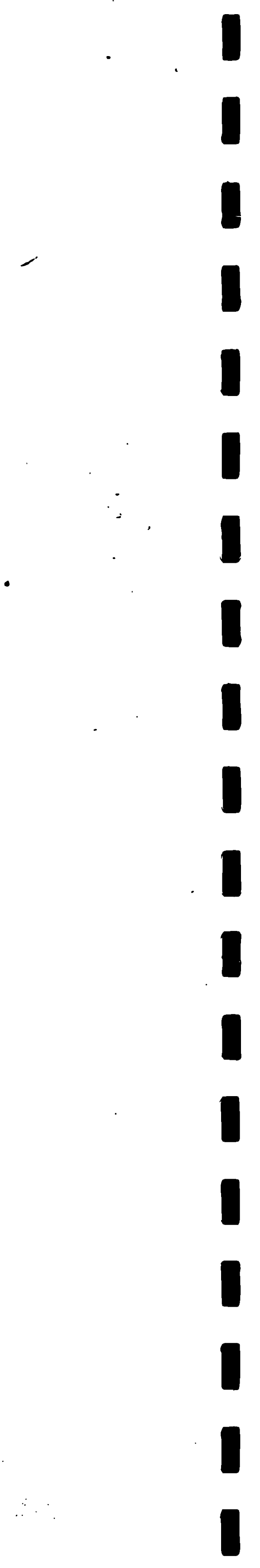

APPENDIX A3

Grain-Size Gradation Curves 


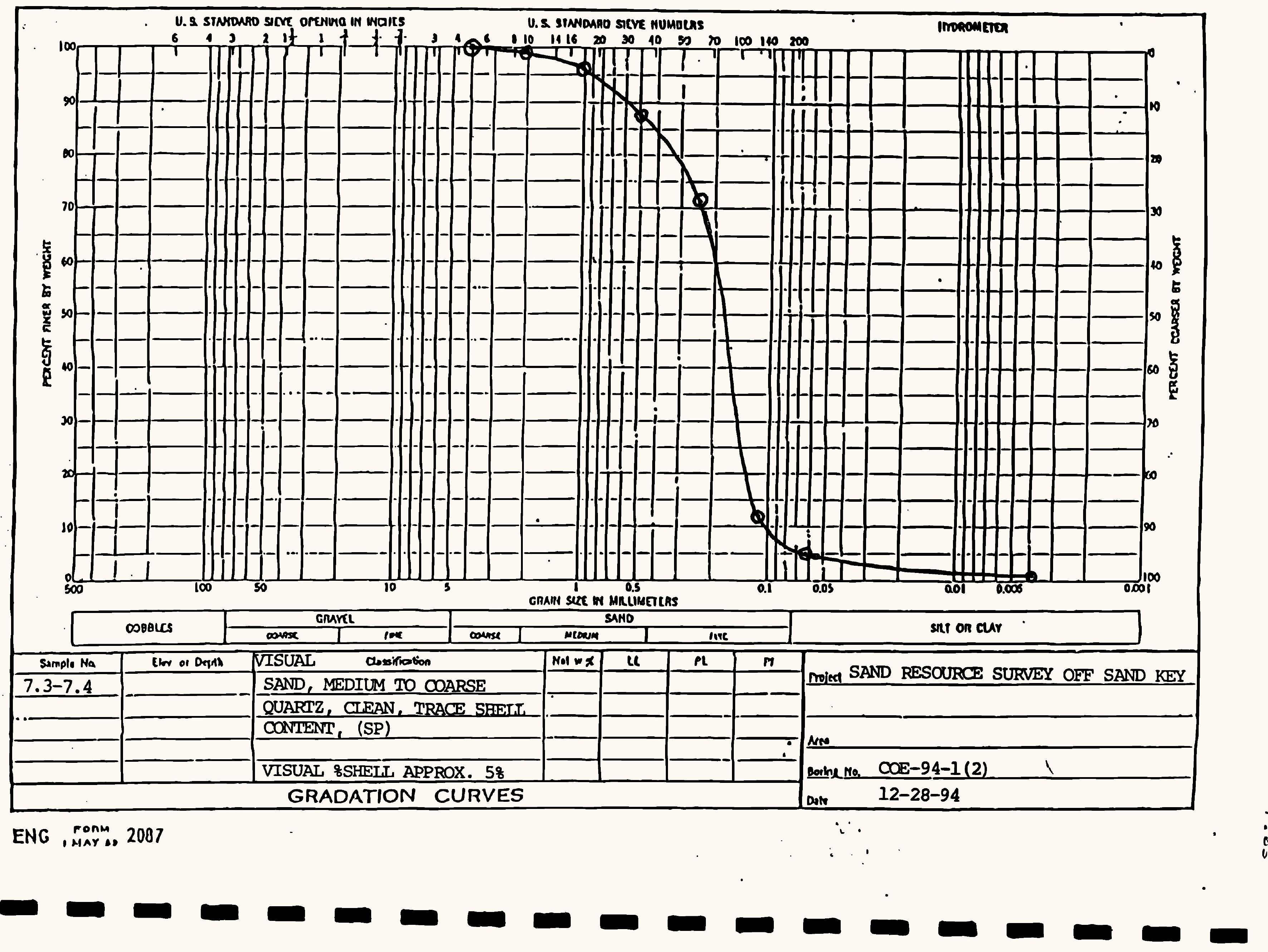




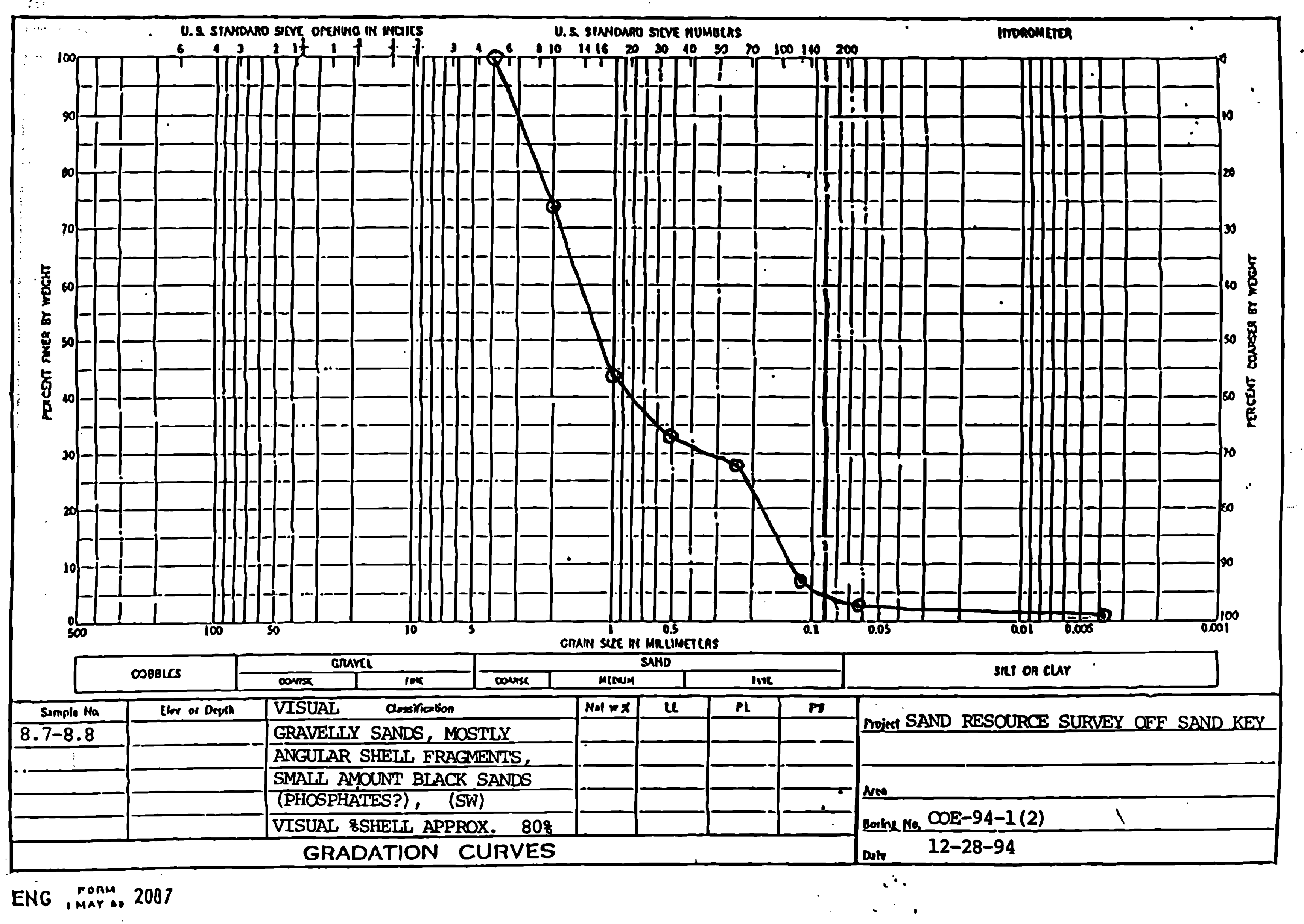




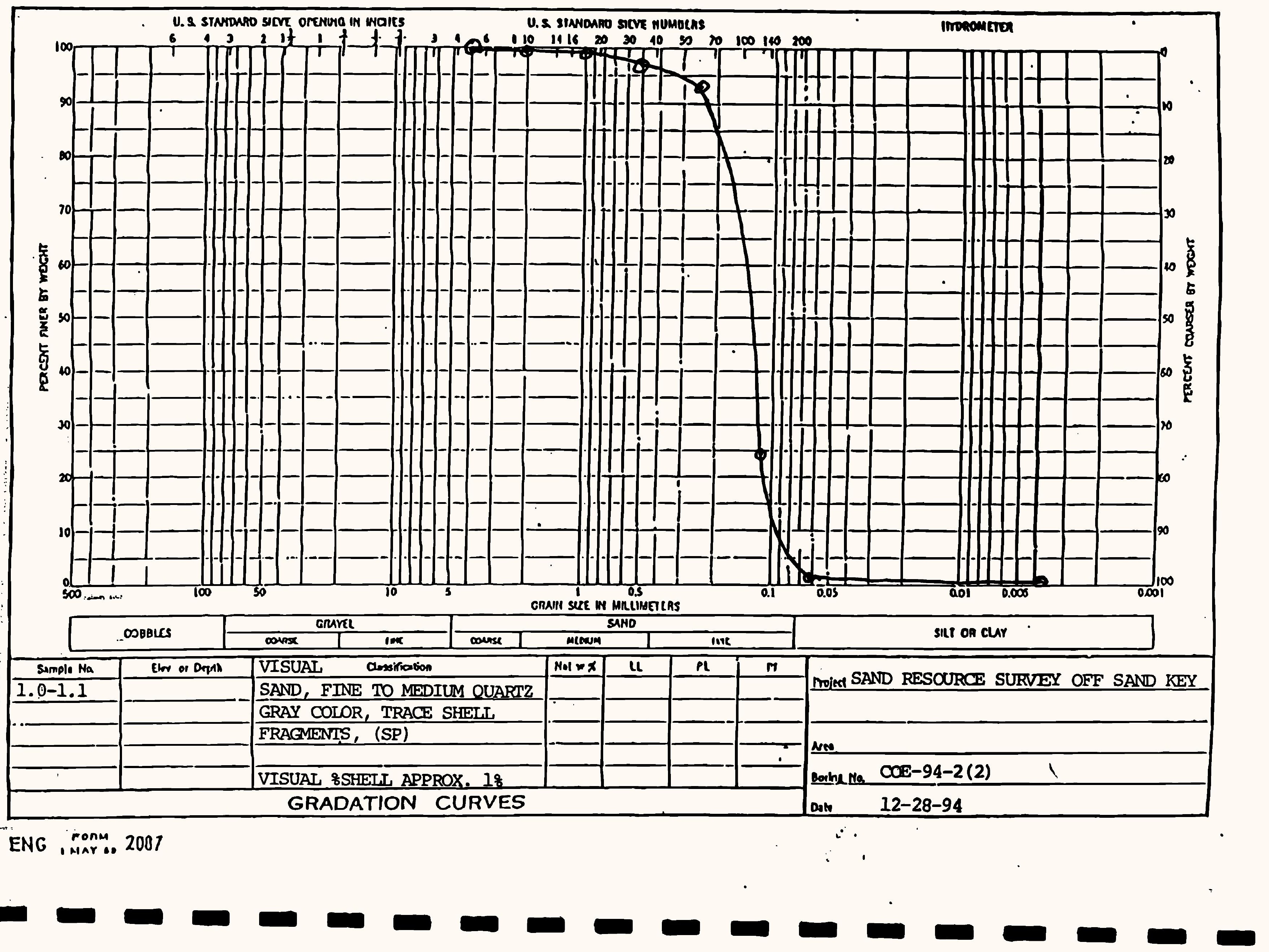




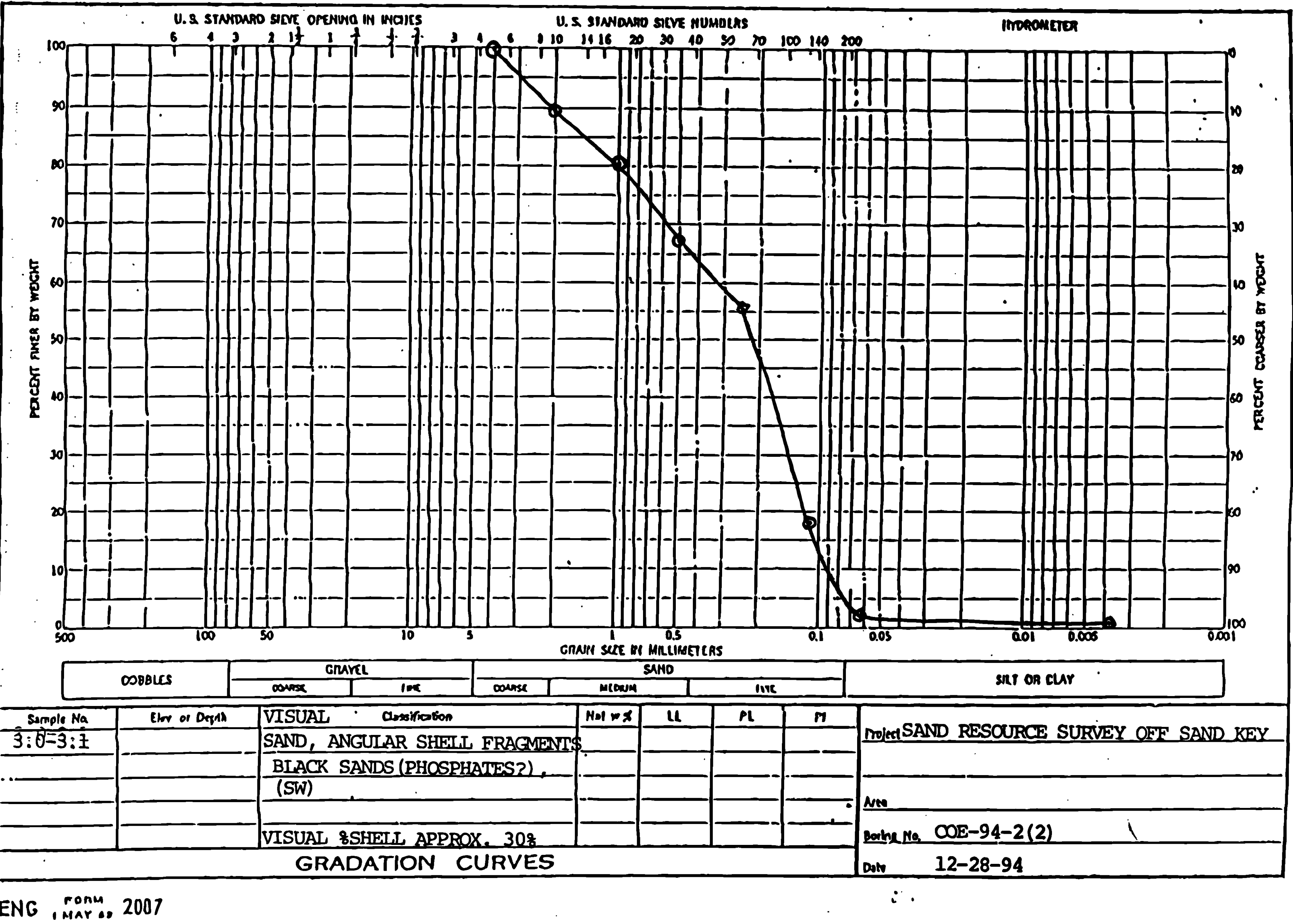




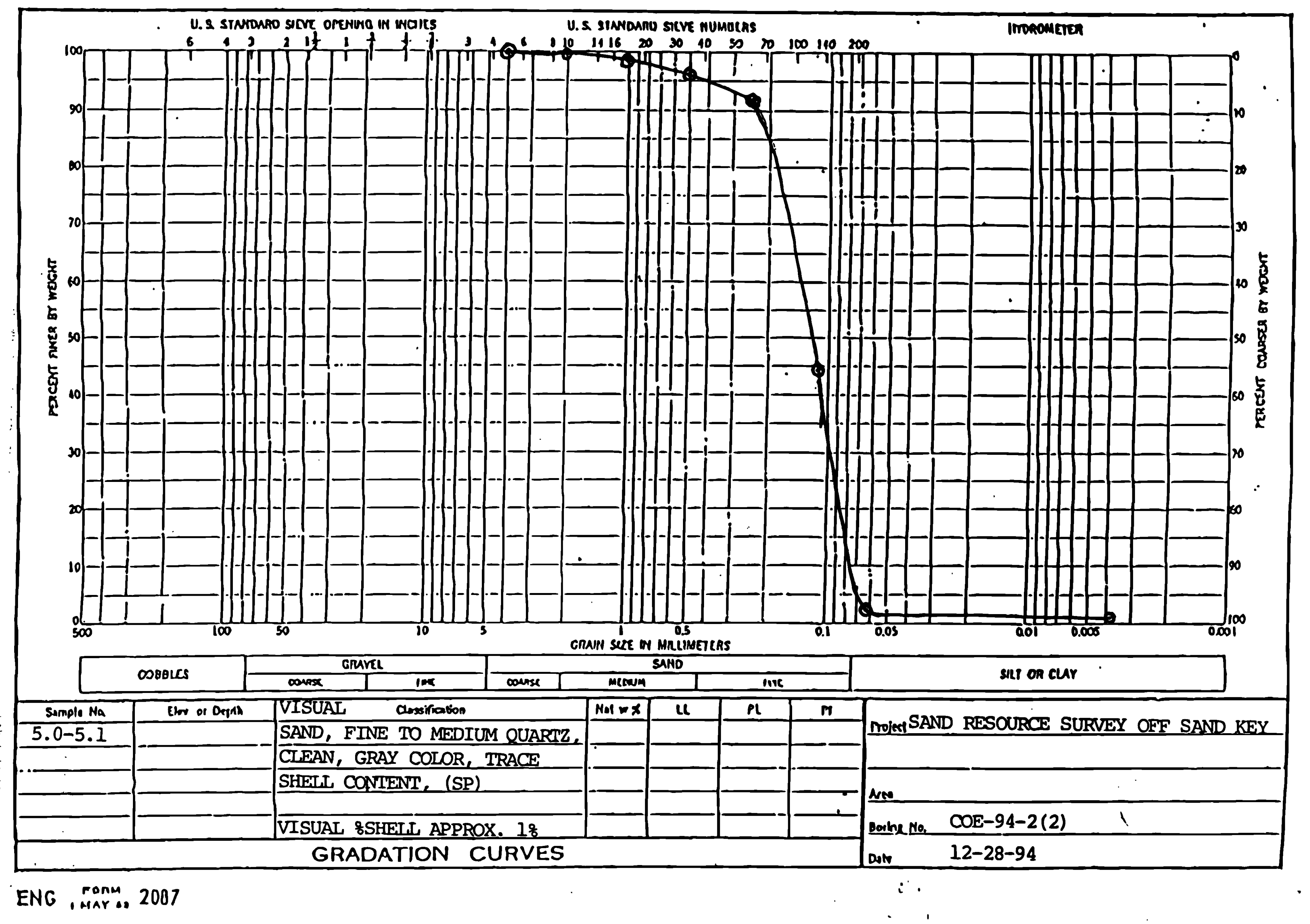




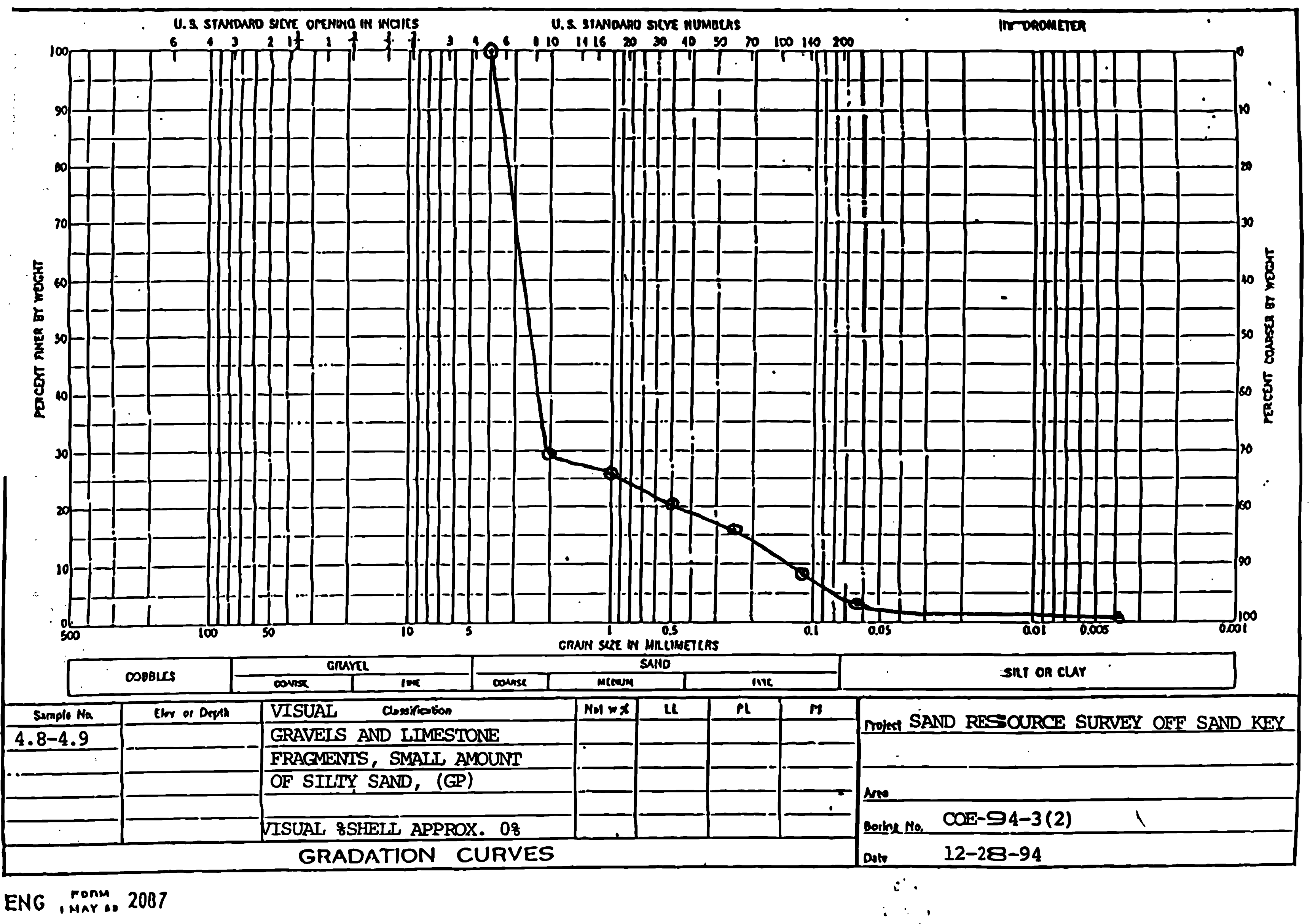




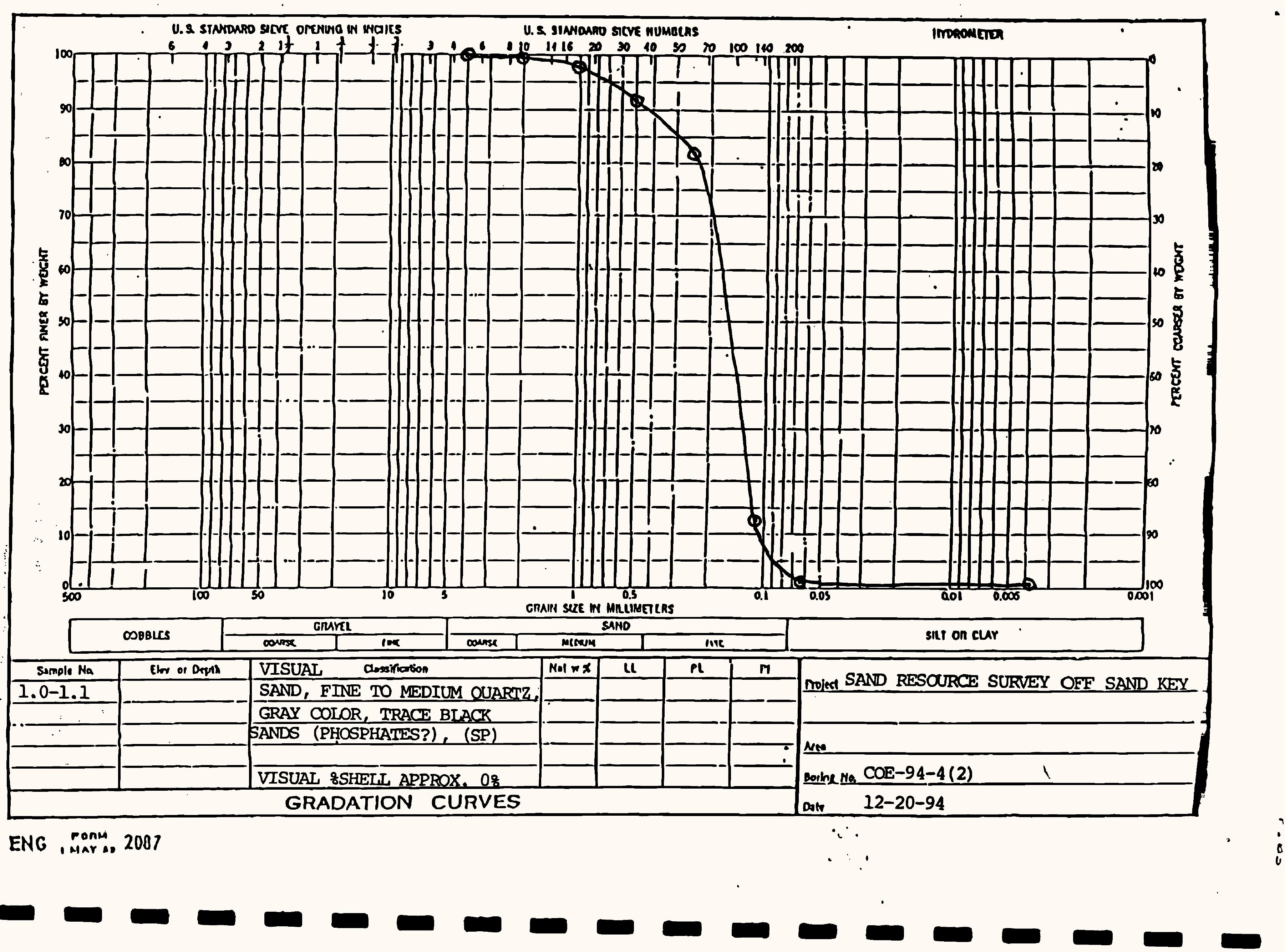




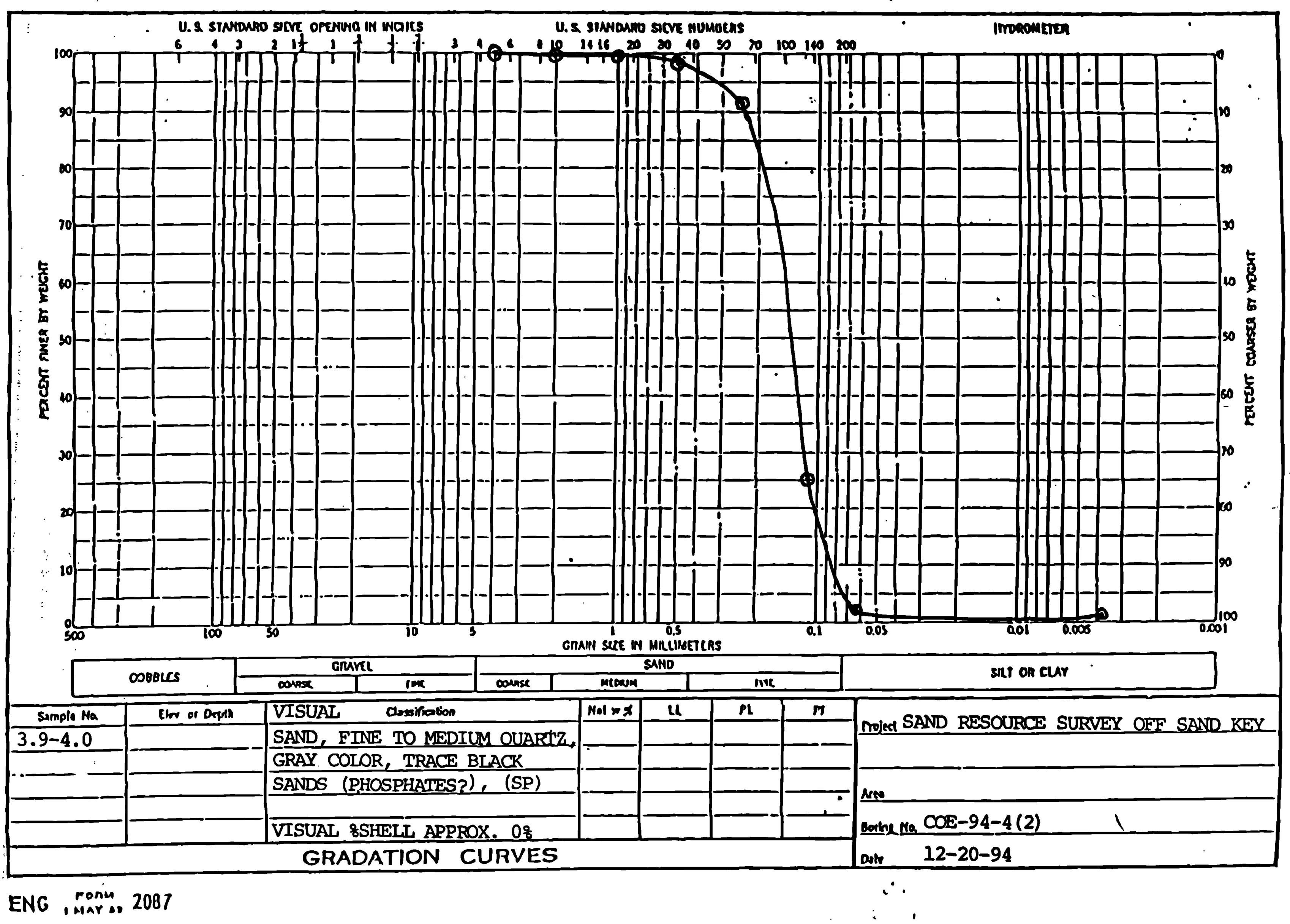




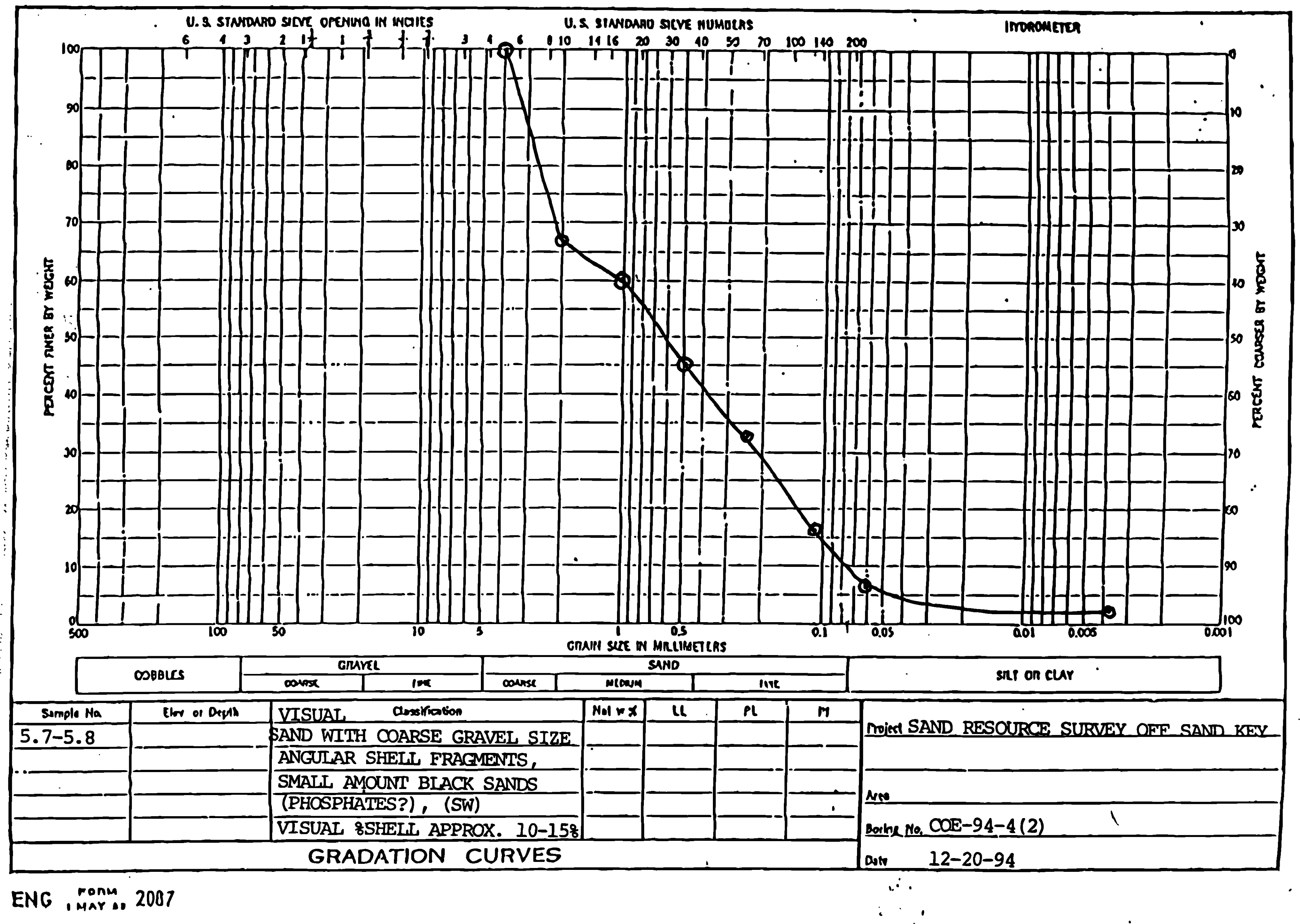




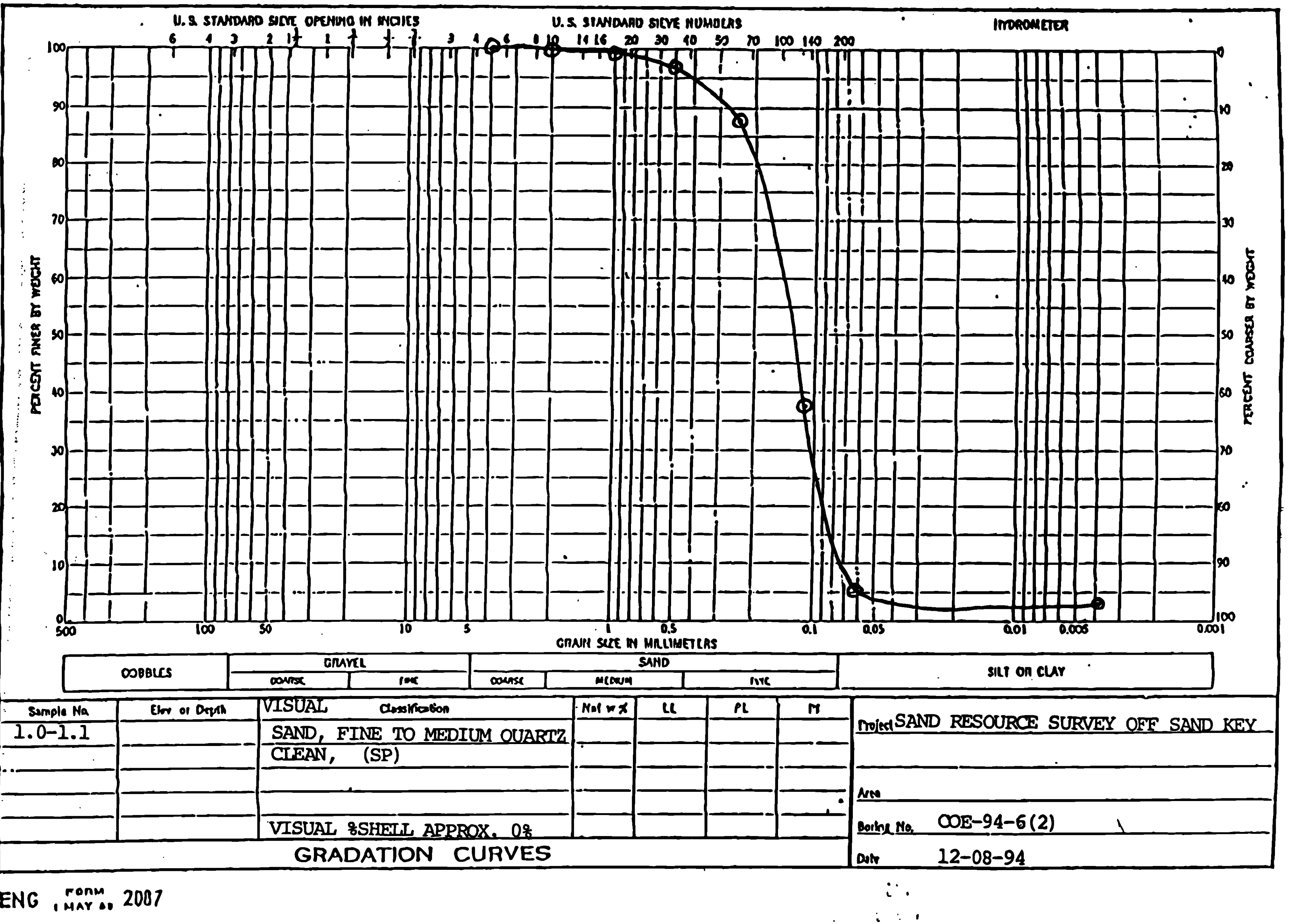




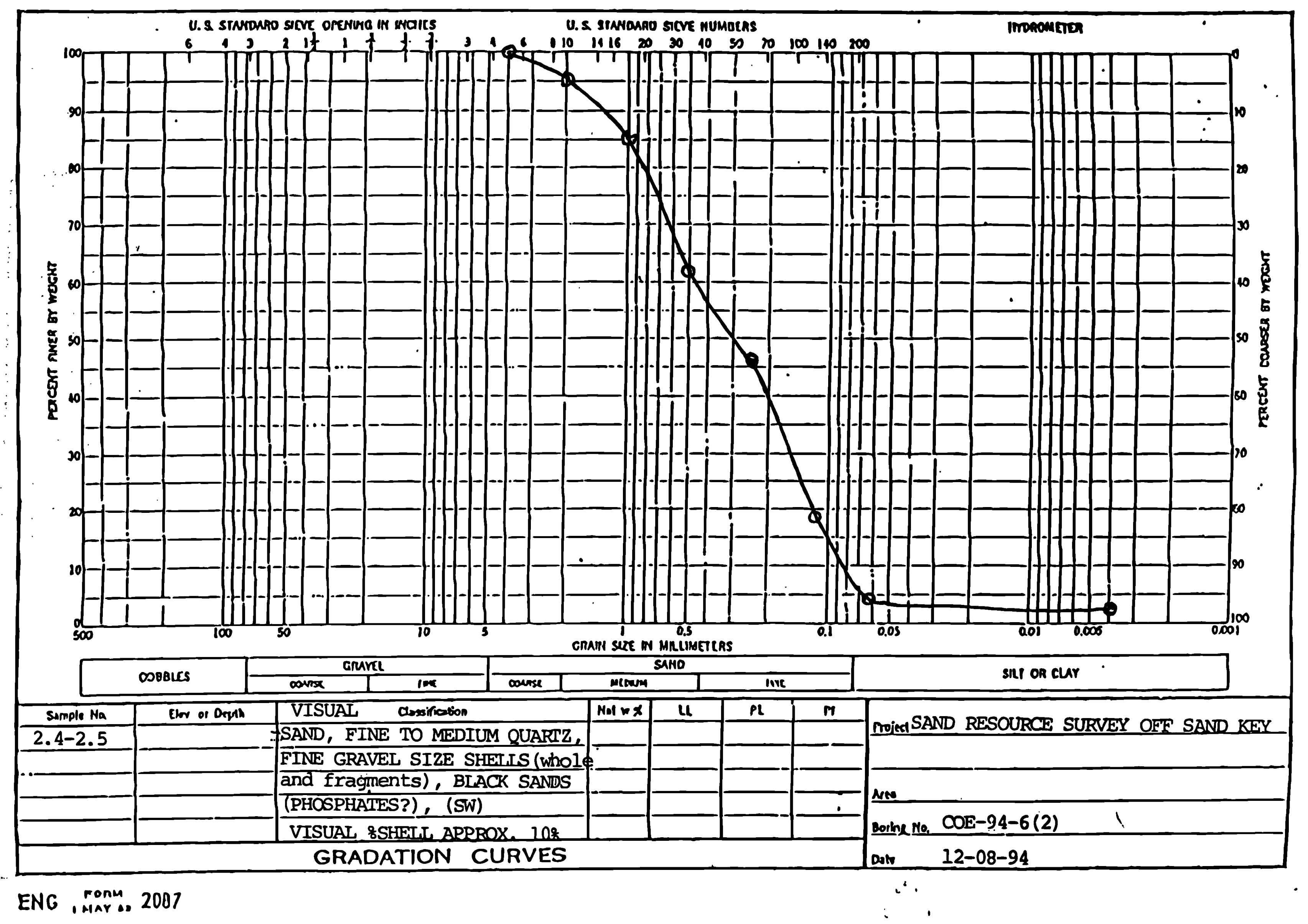




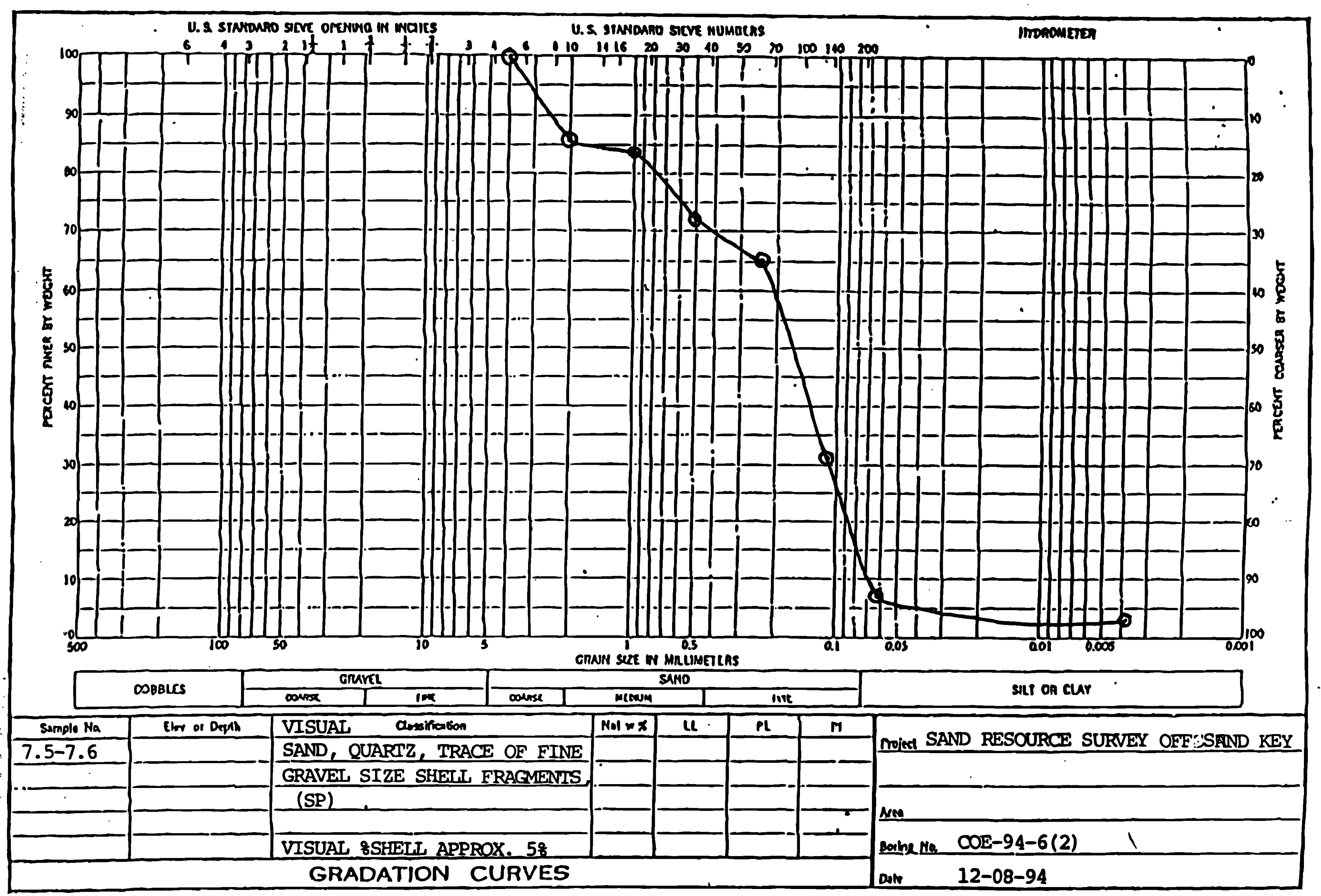

ENG , MANM 2007 


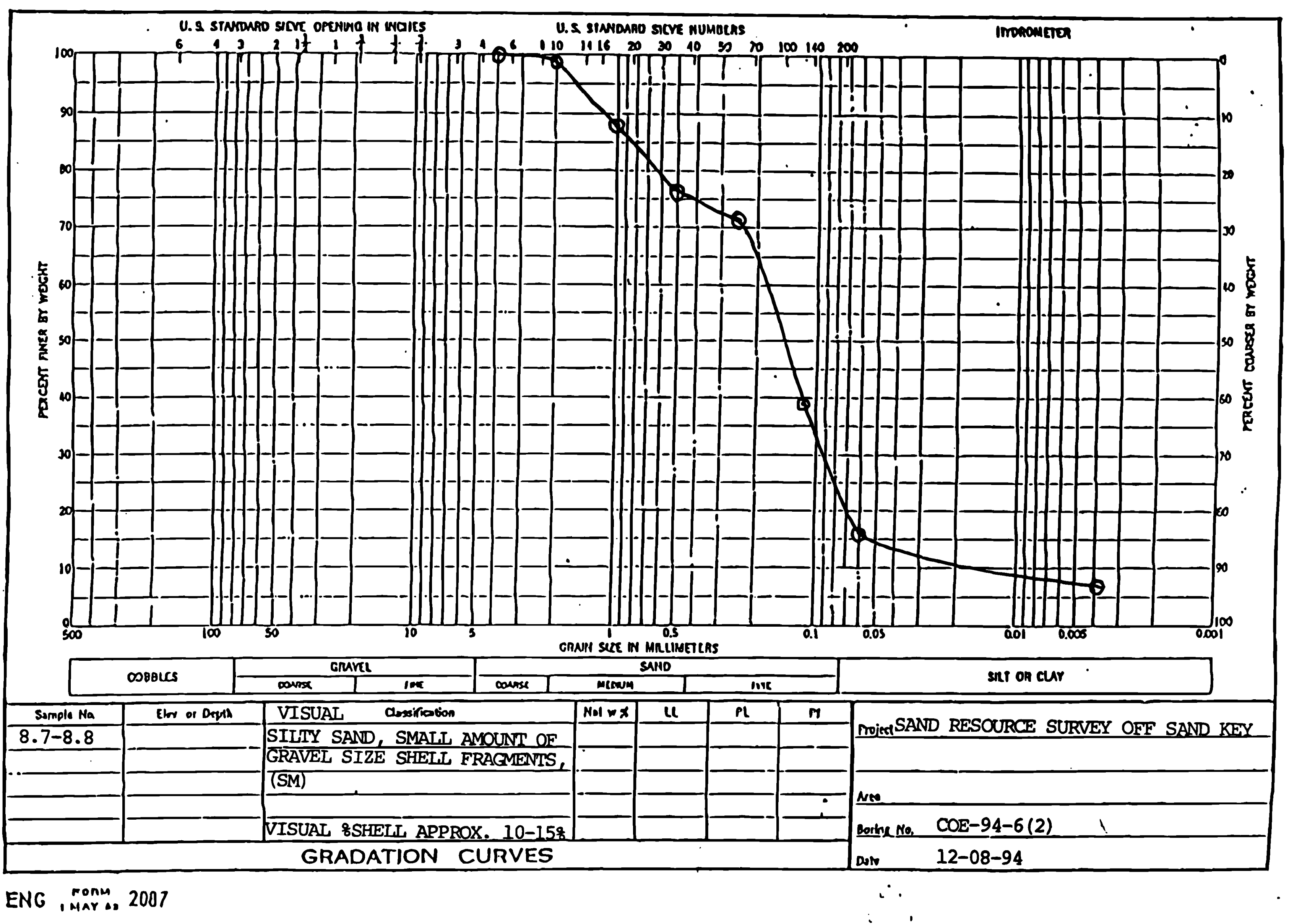




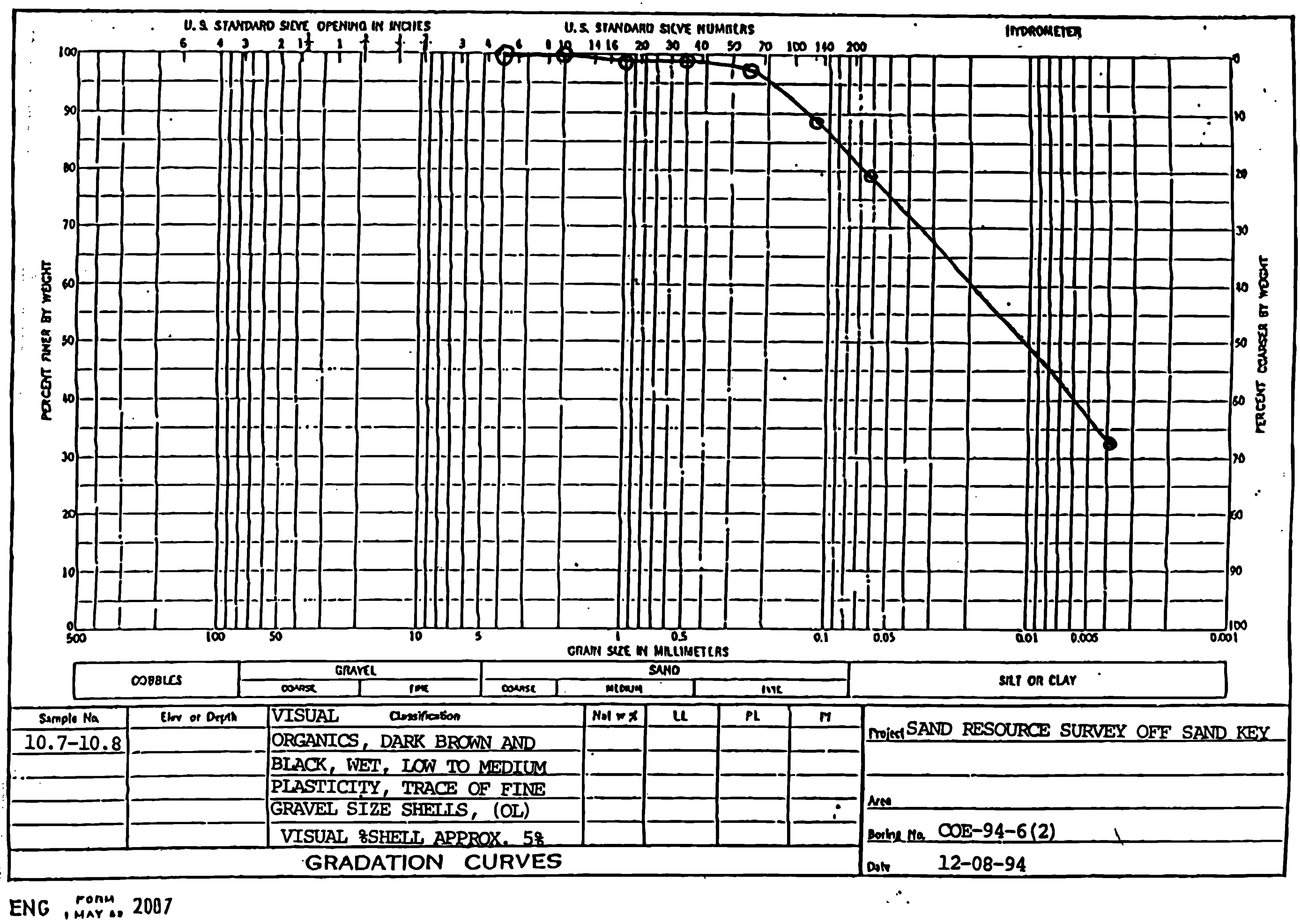




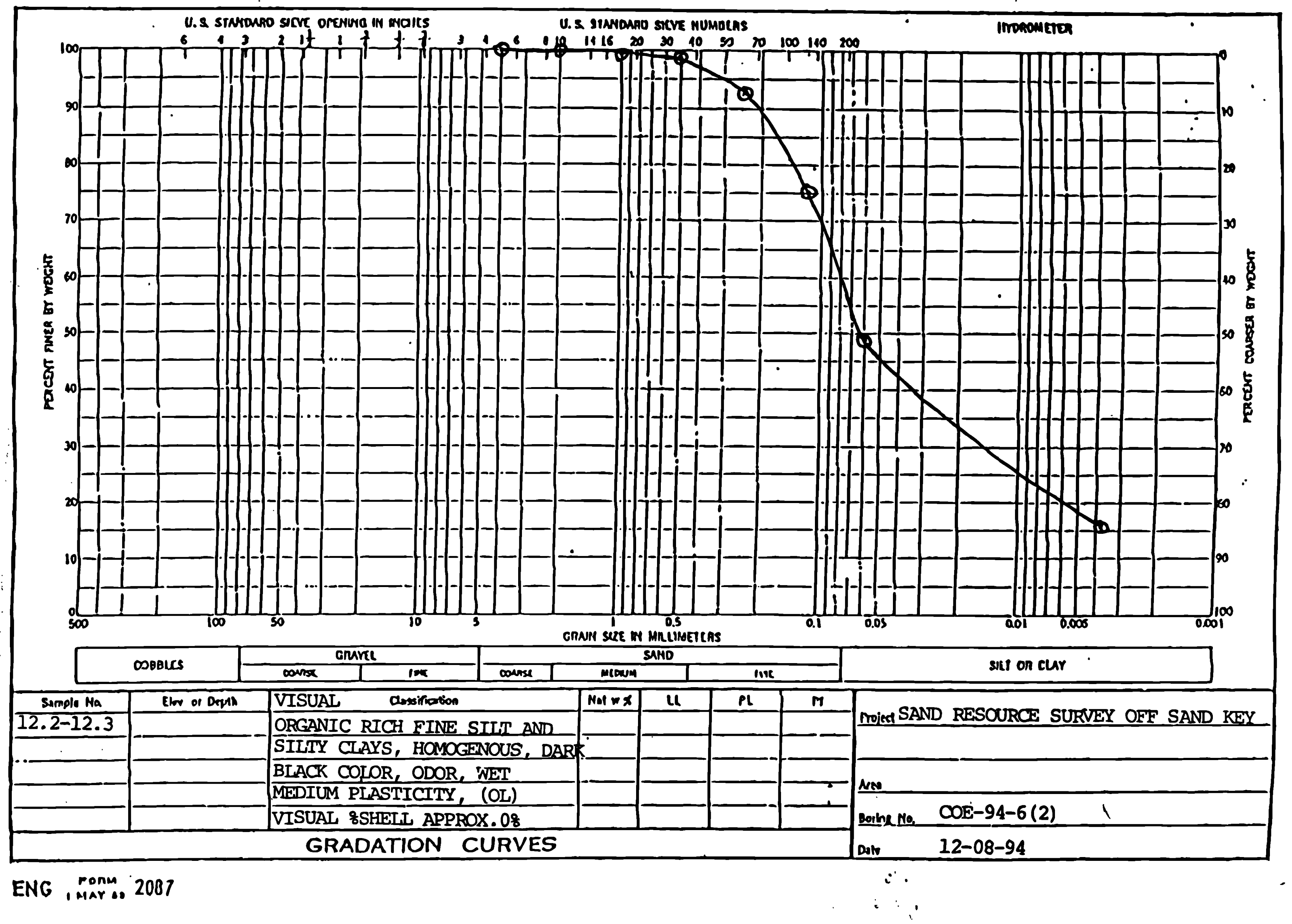




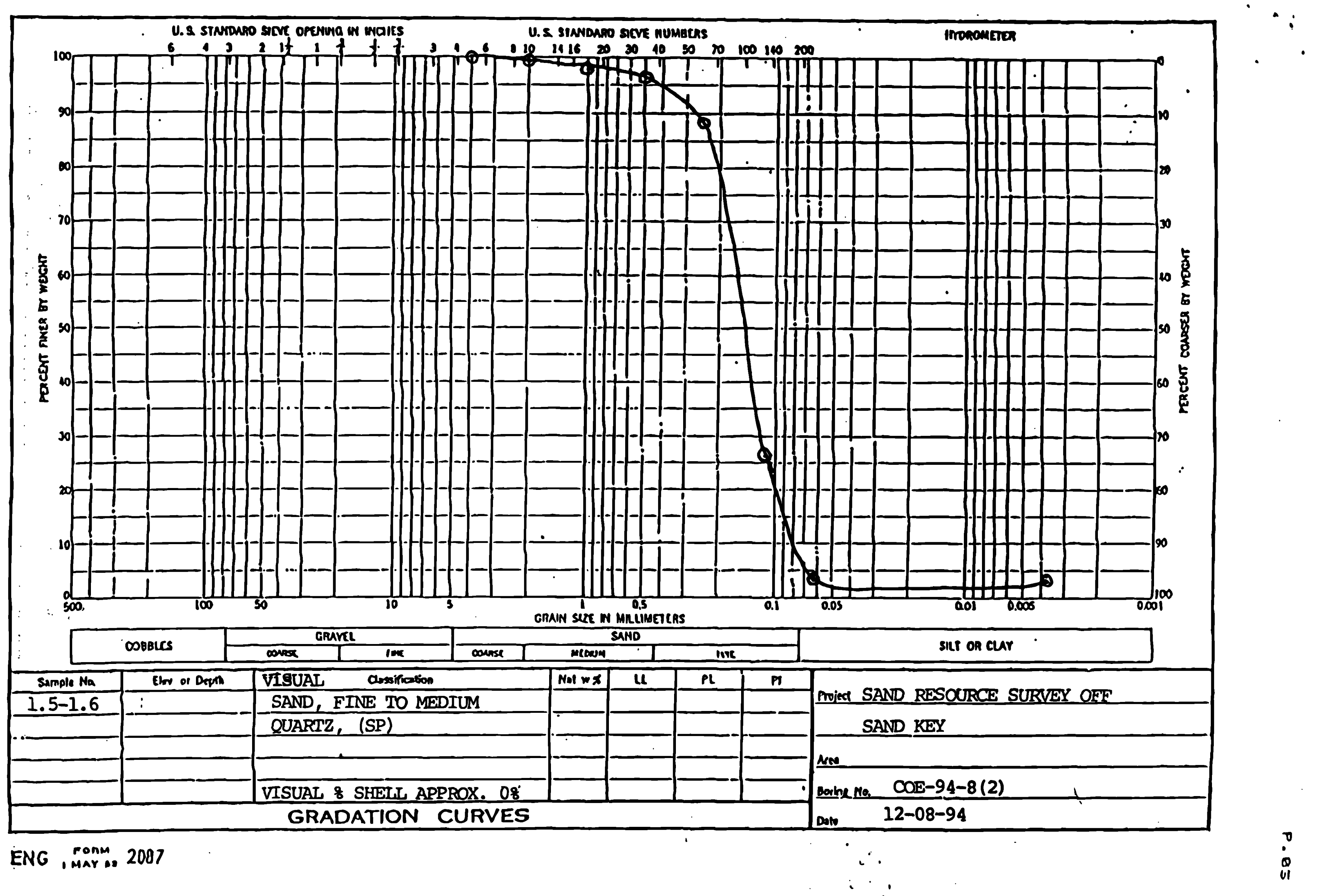




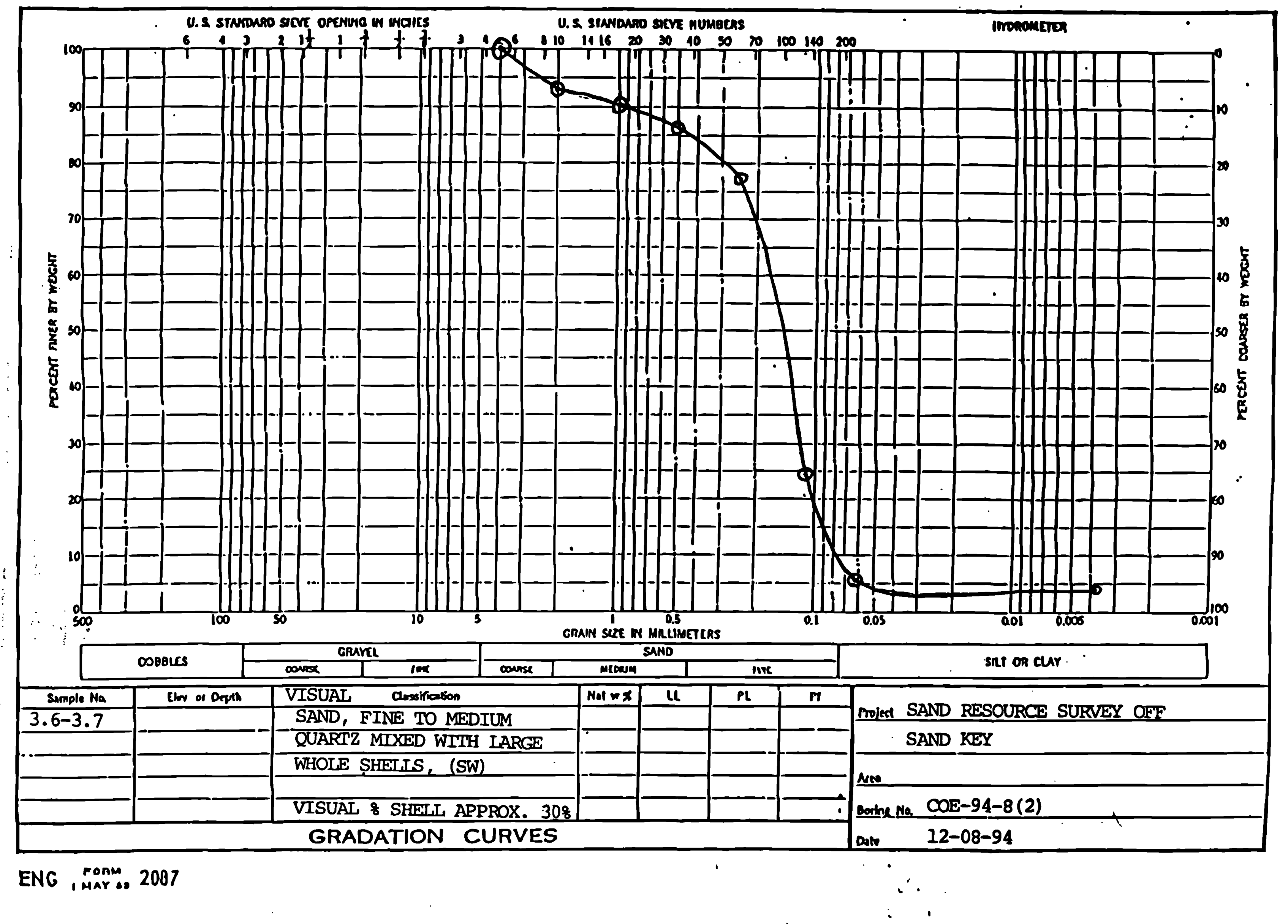




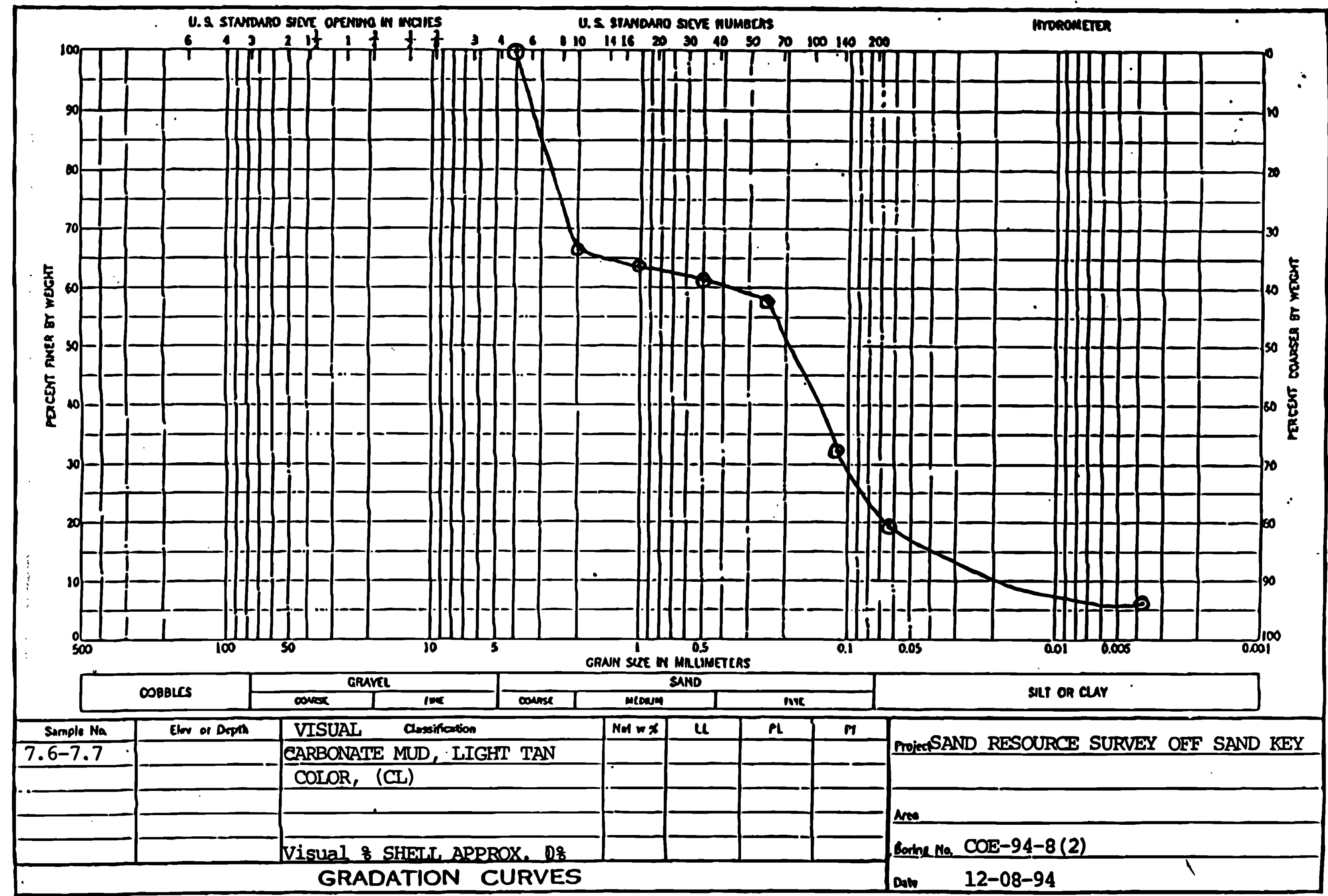

ENG , marm 2087 


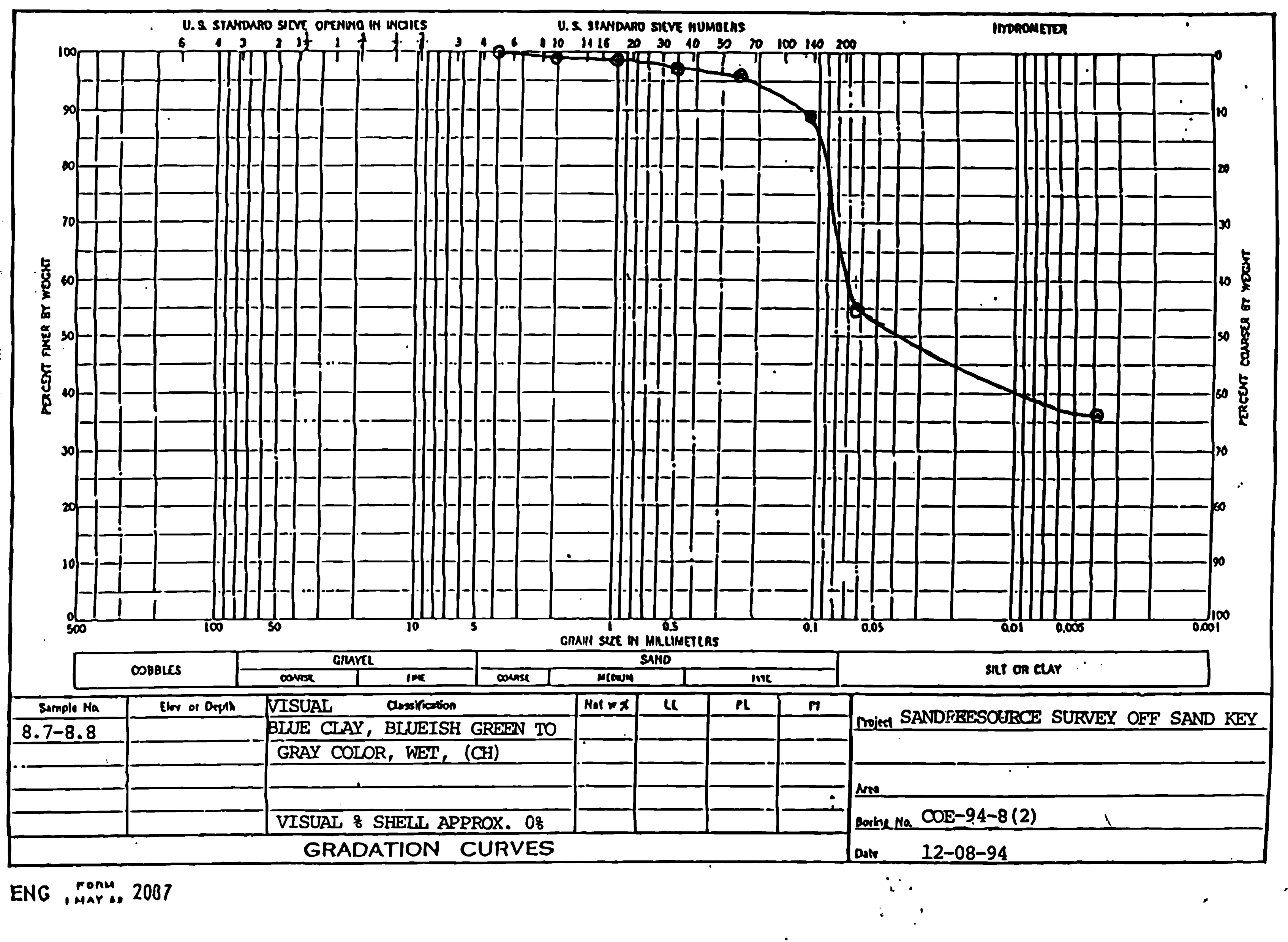




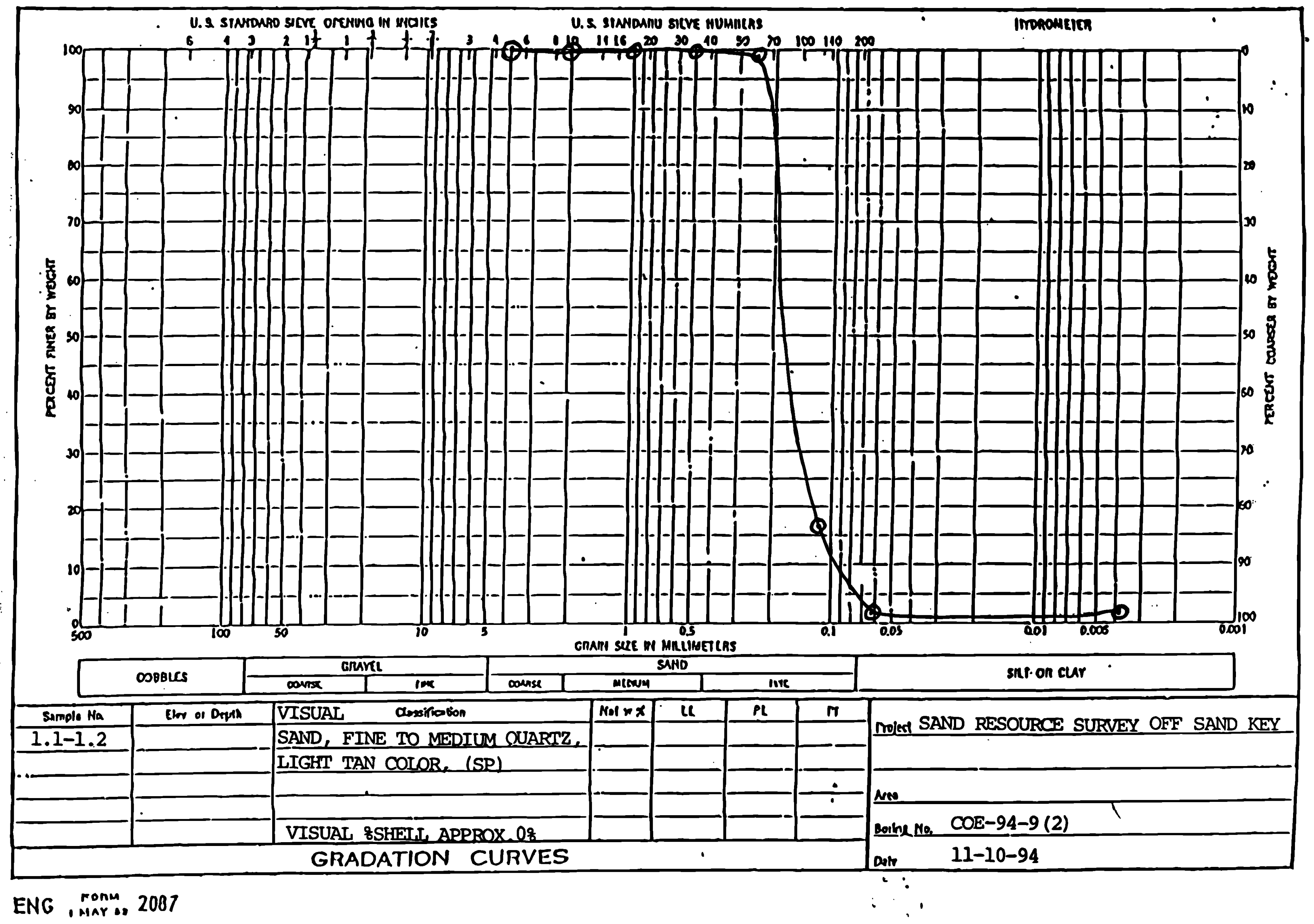




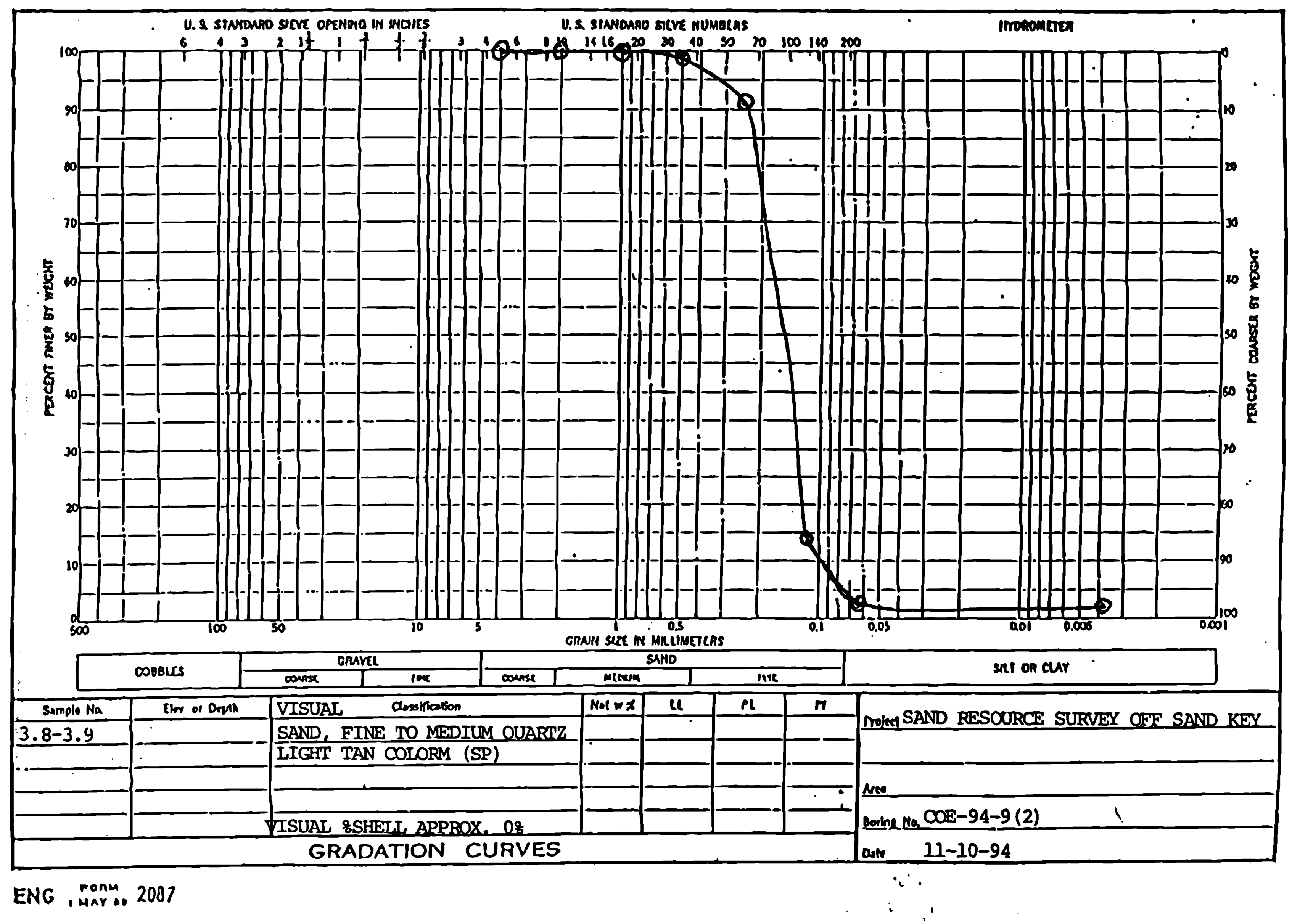




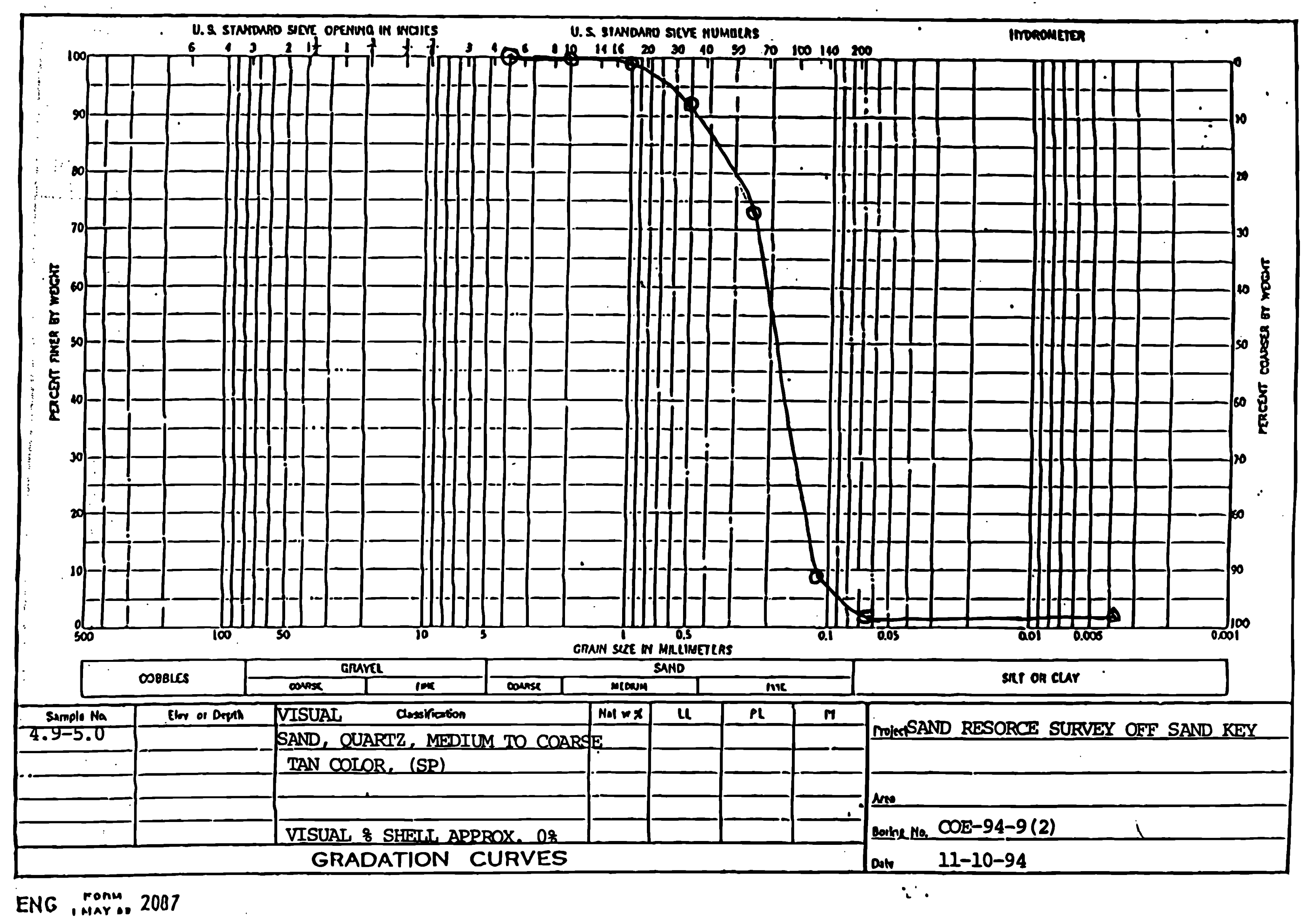




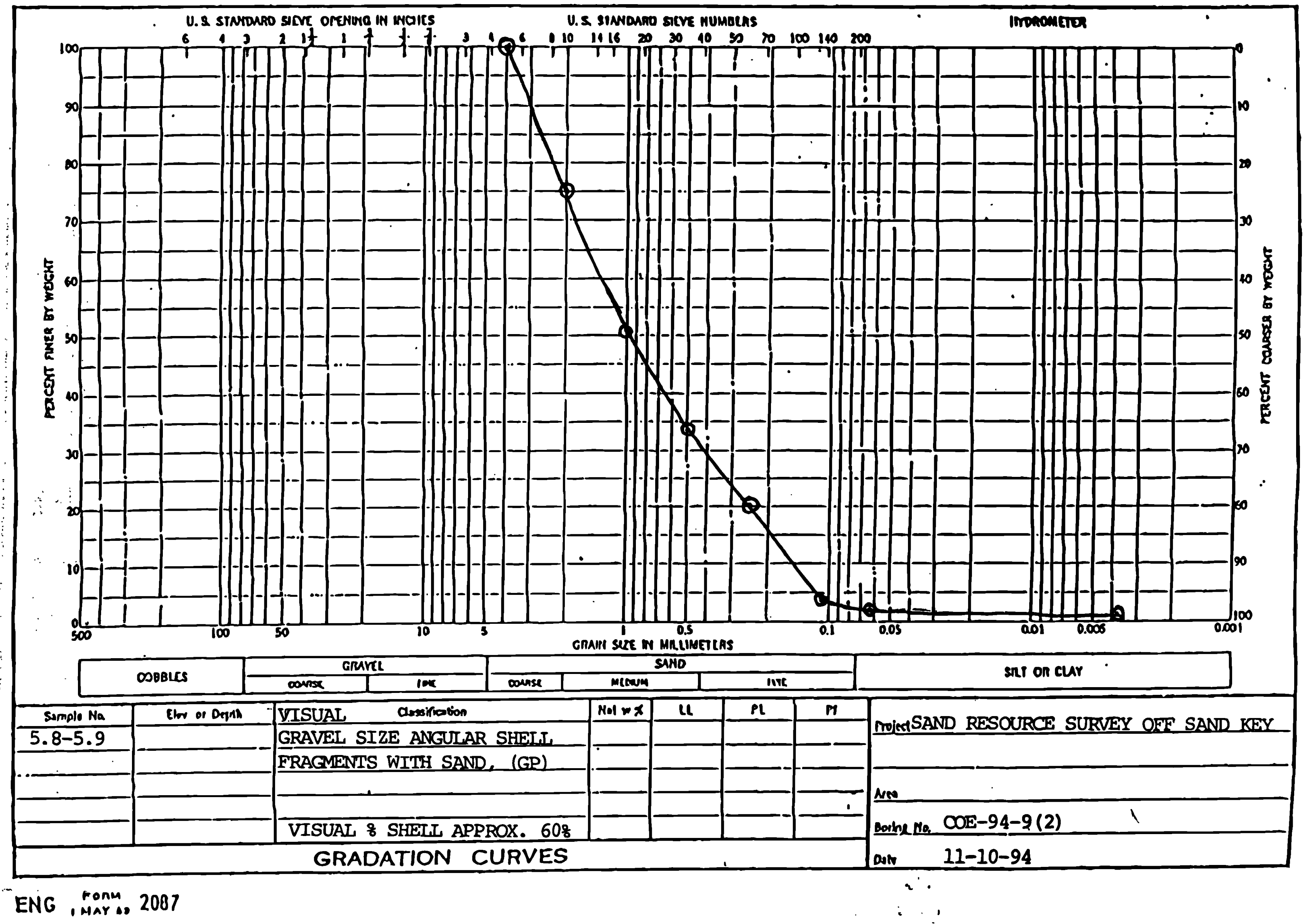




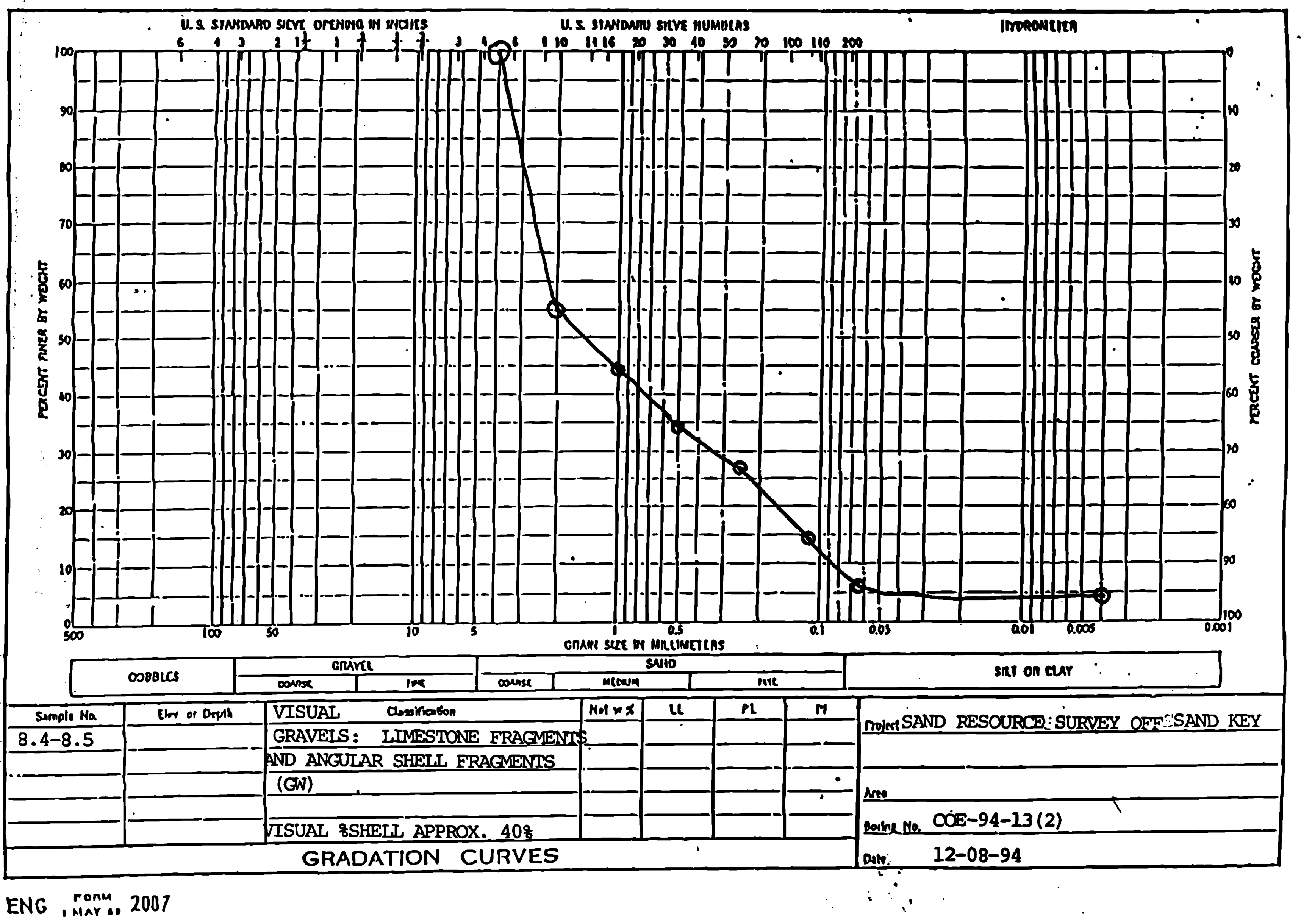




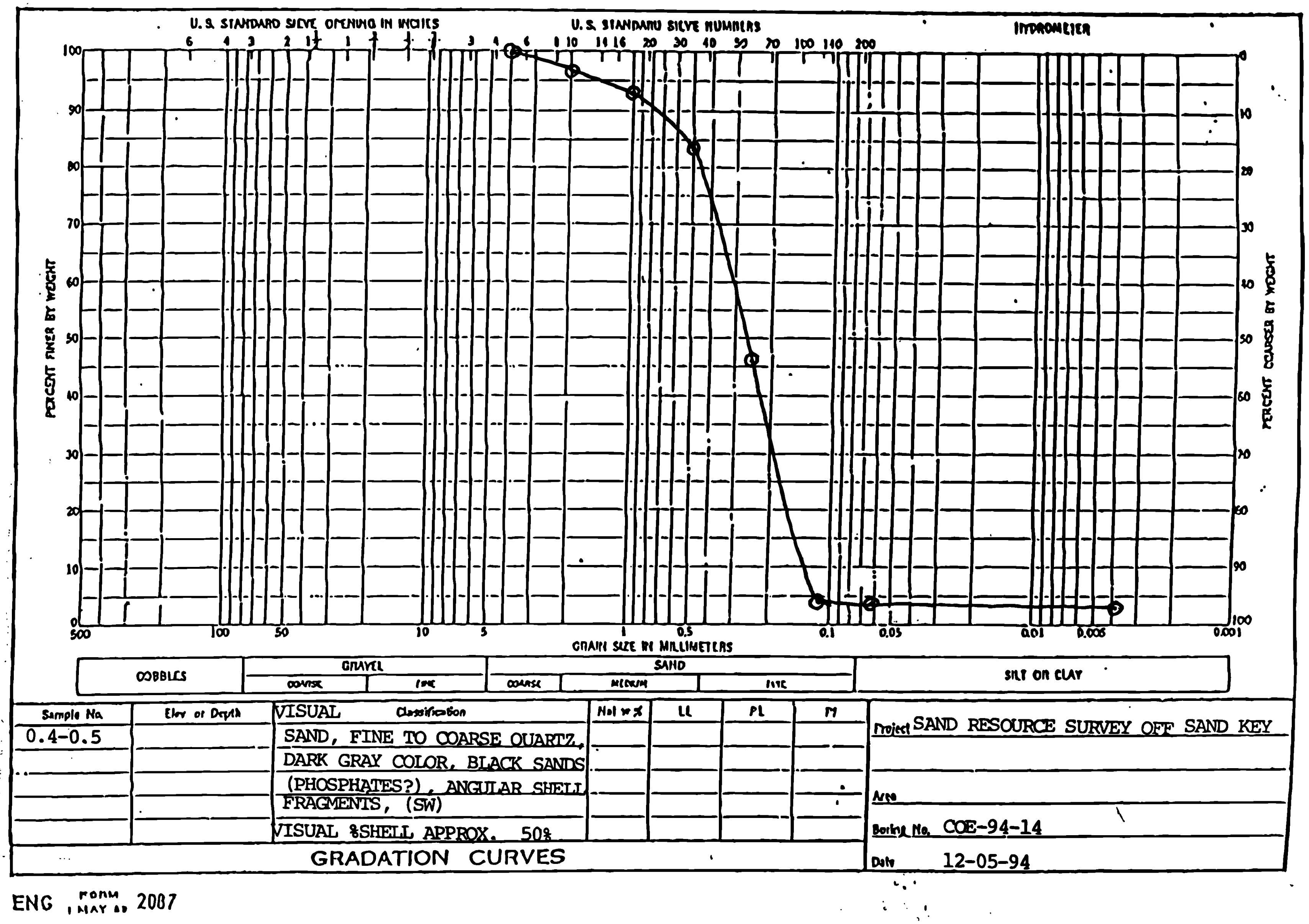




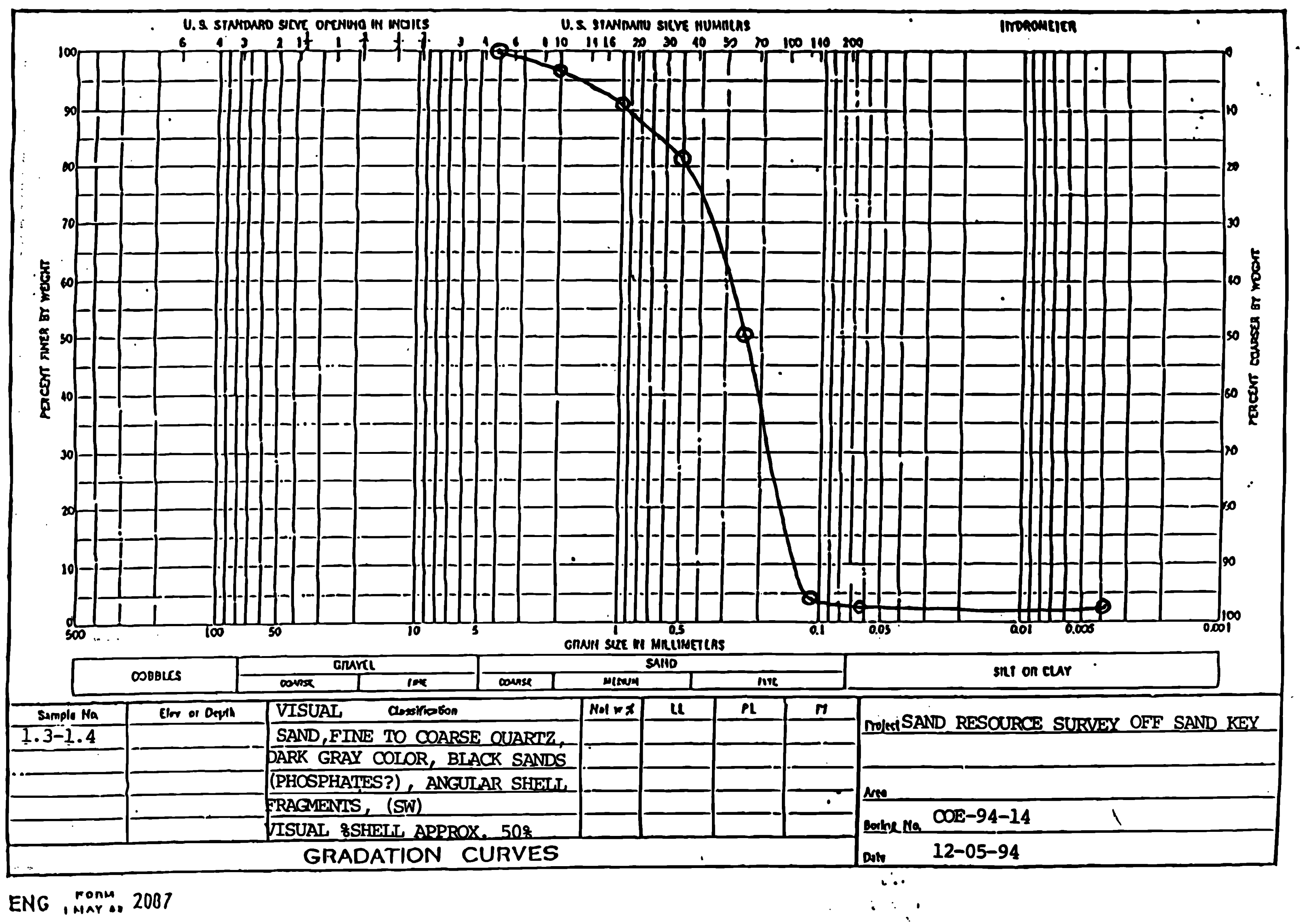




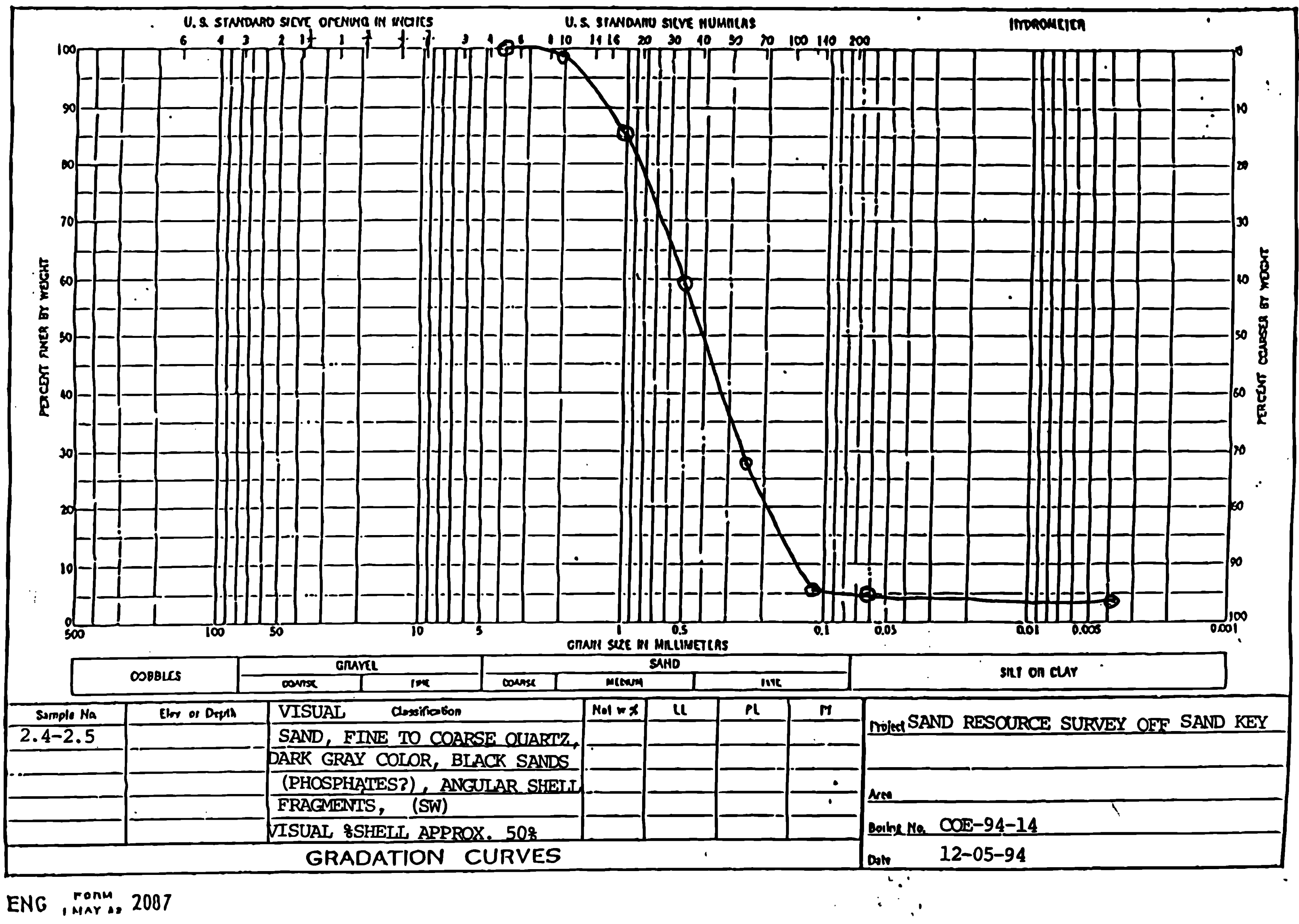




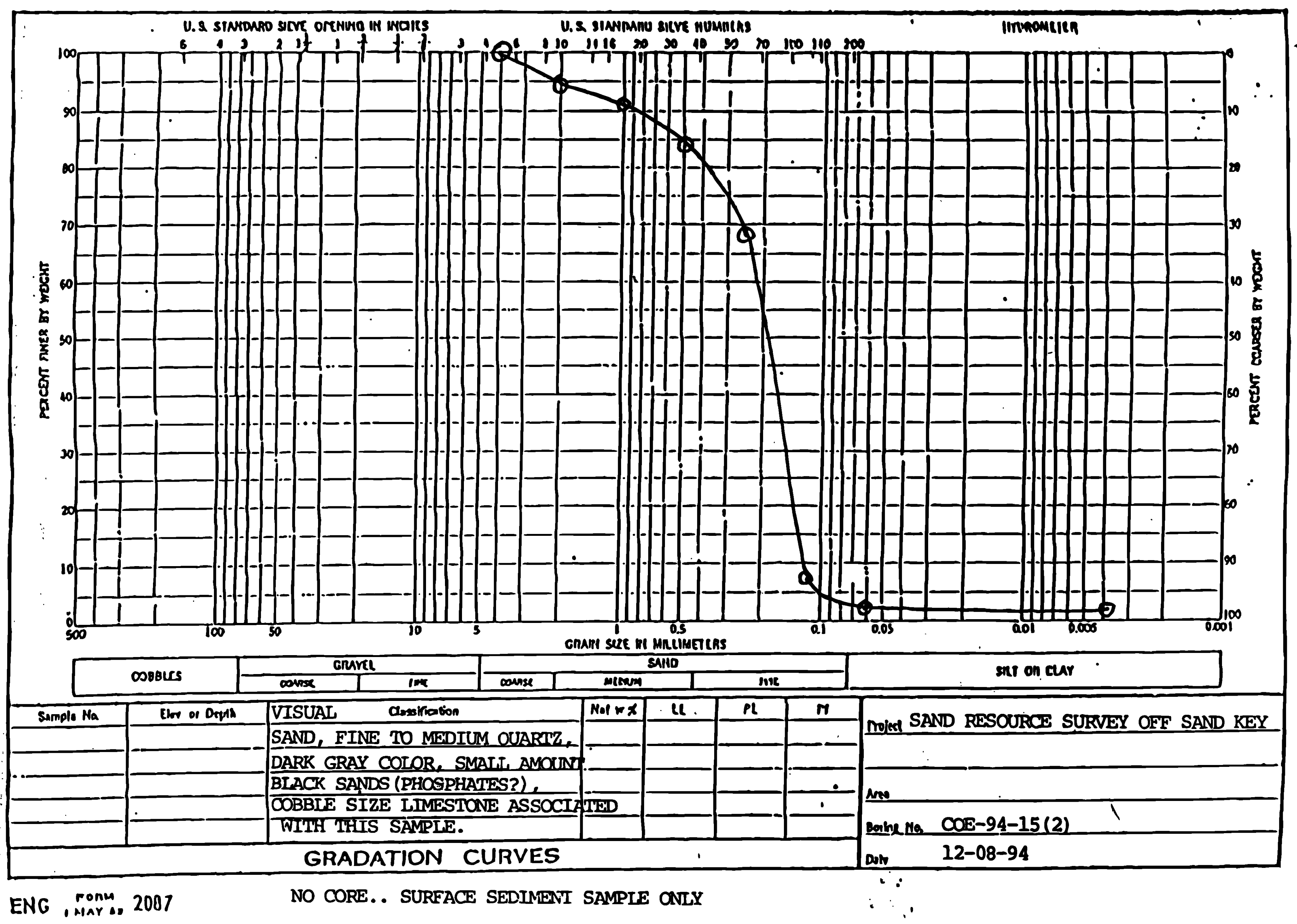




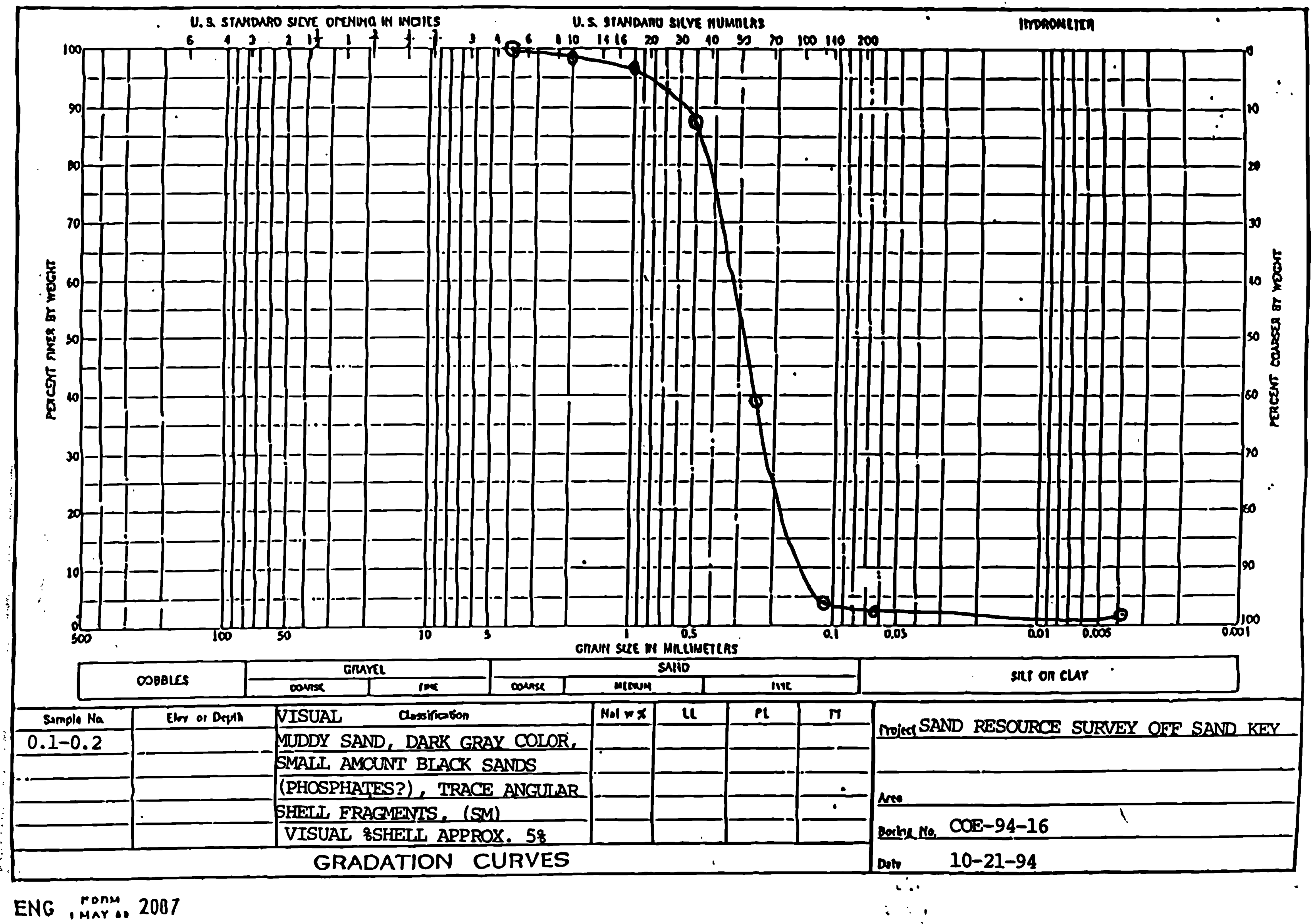




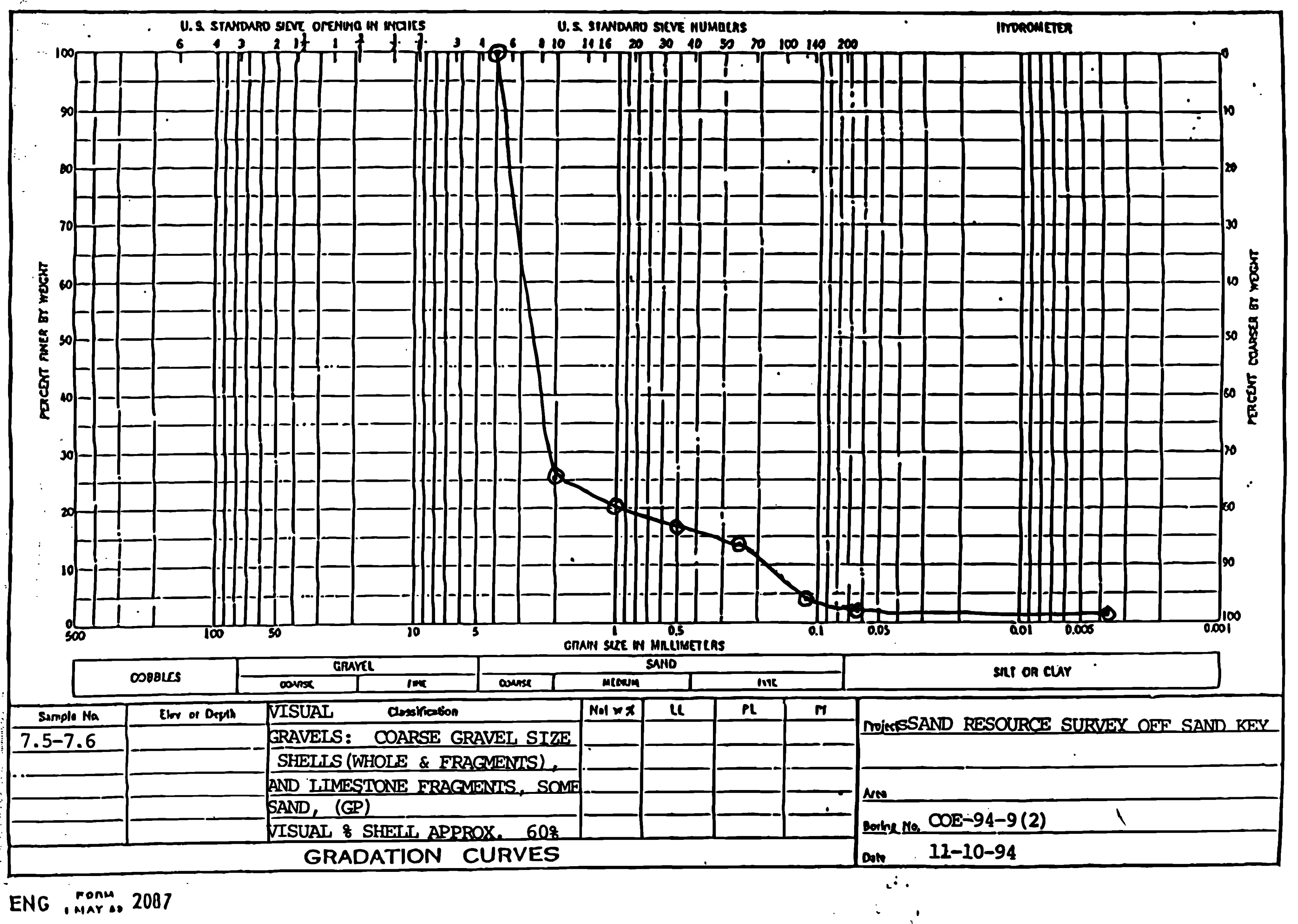




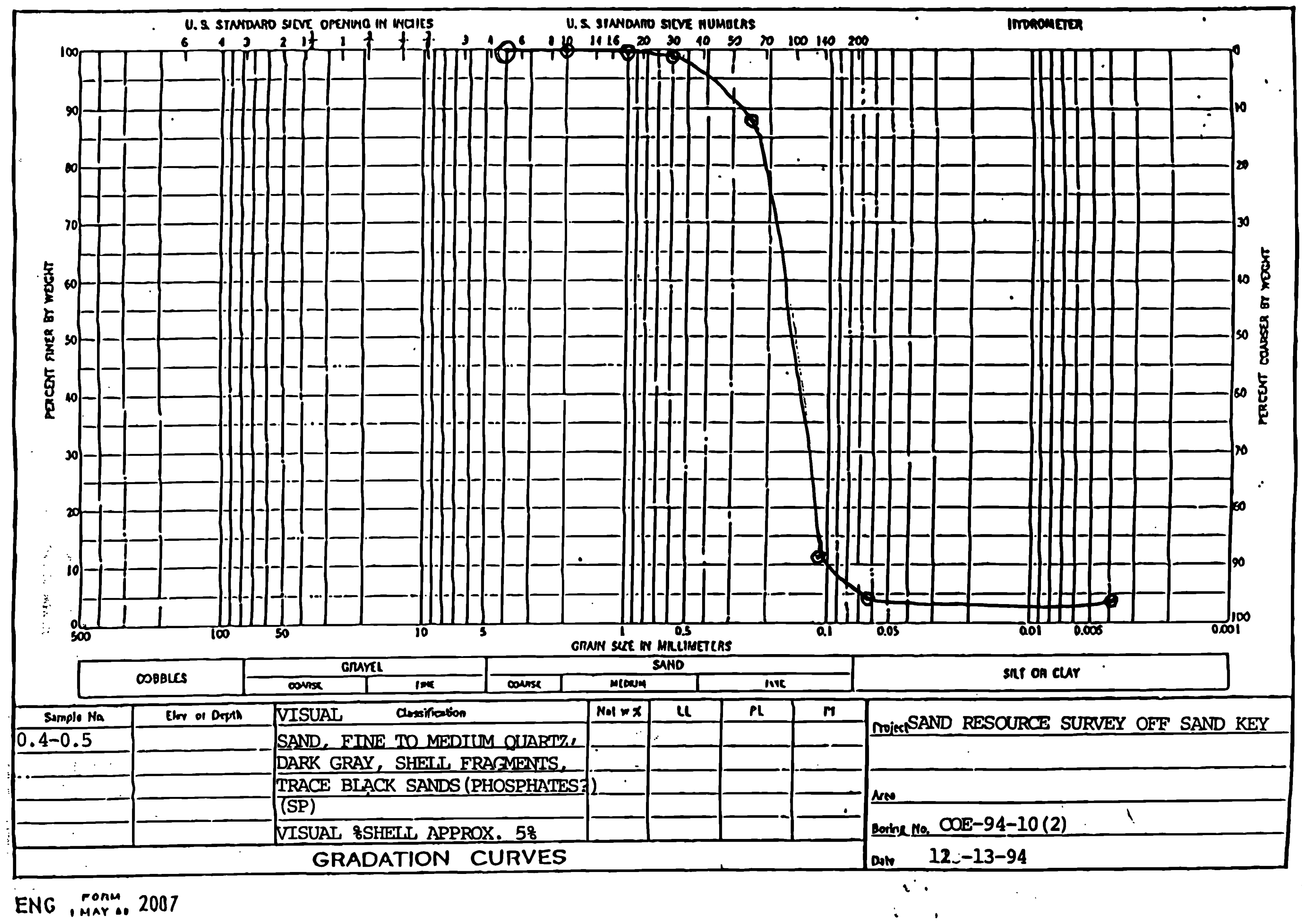




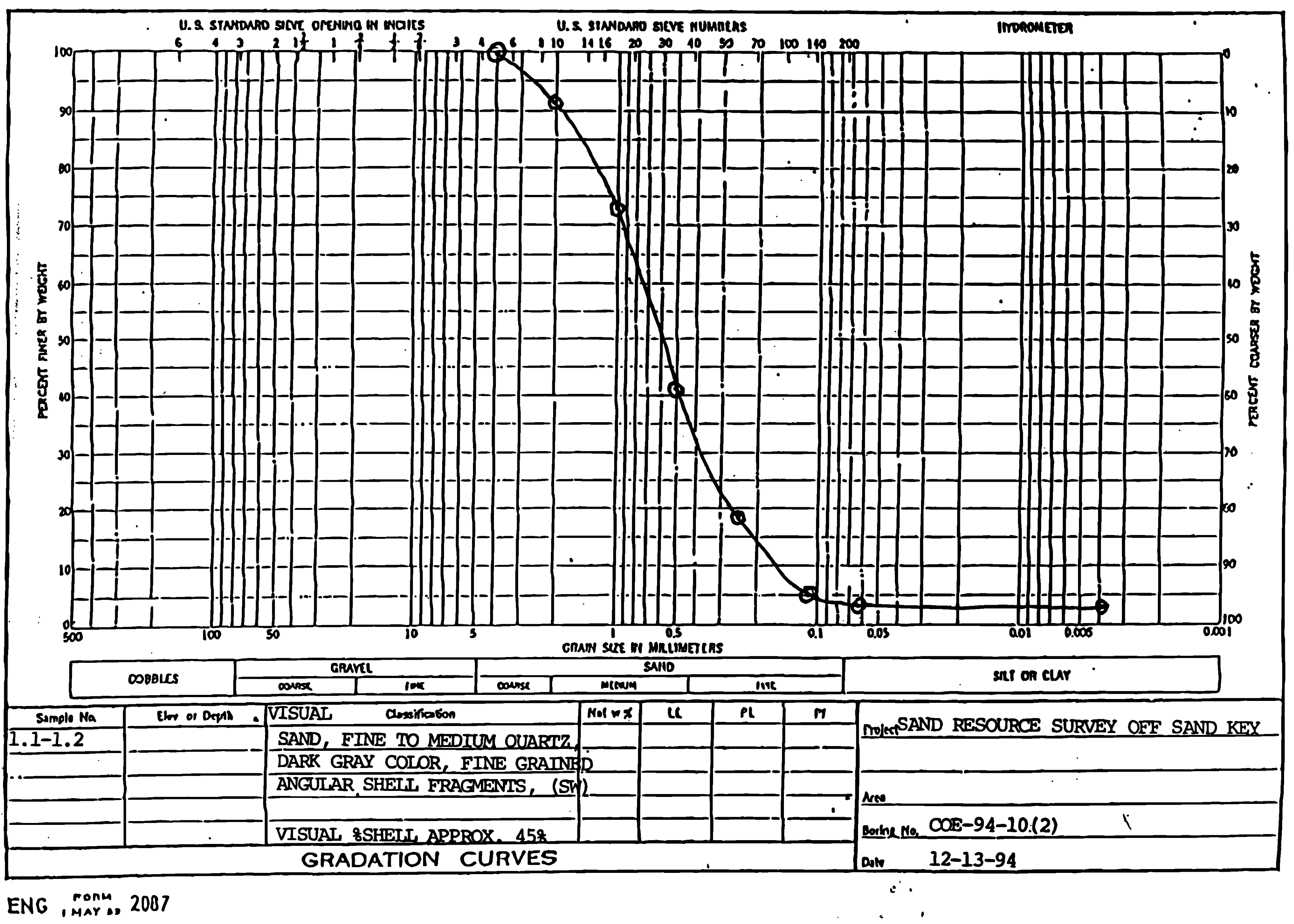




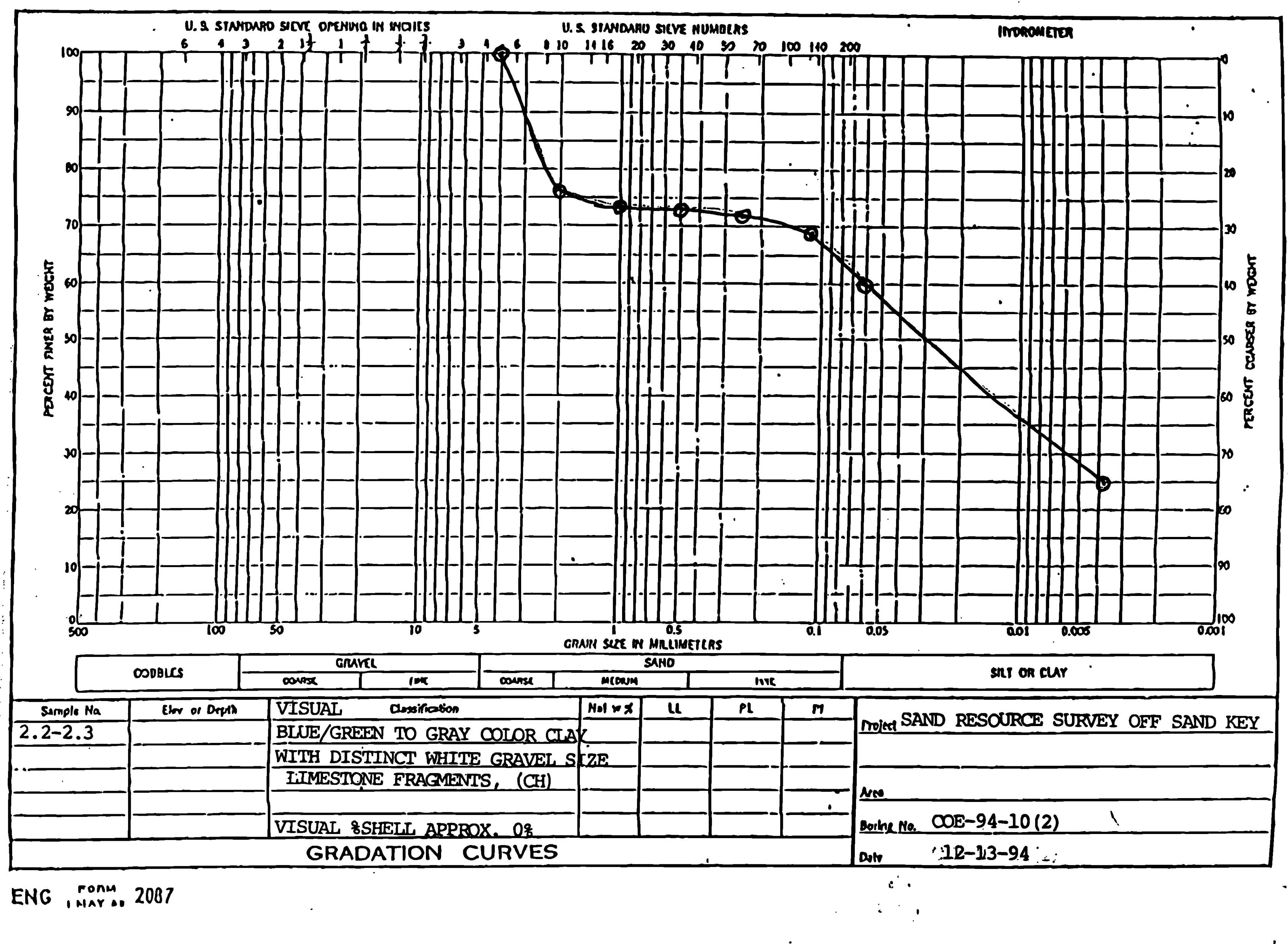




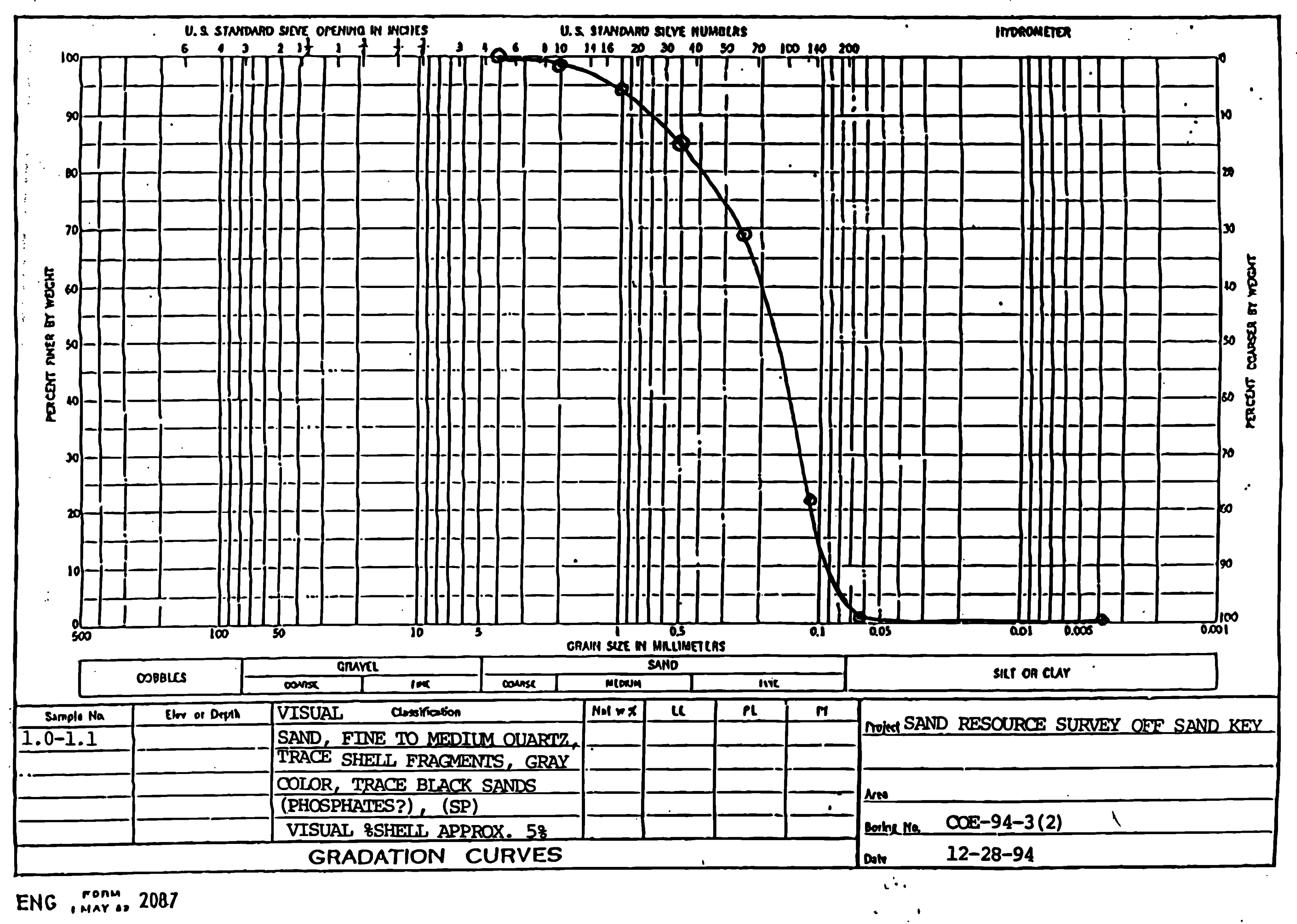




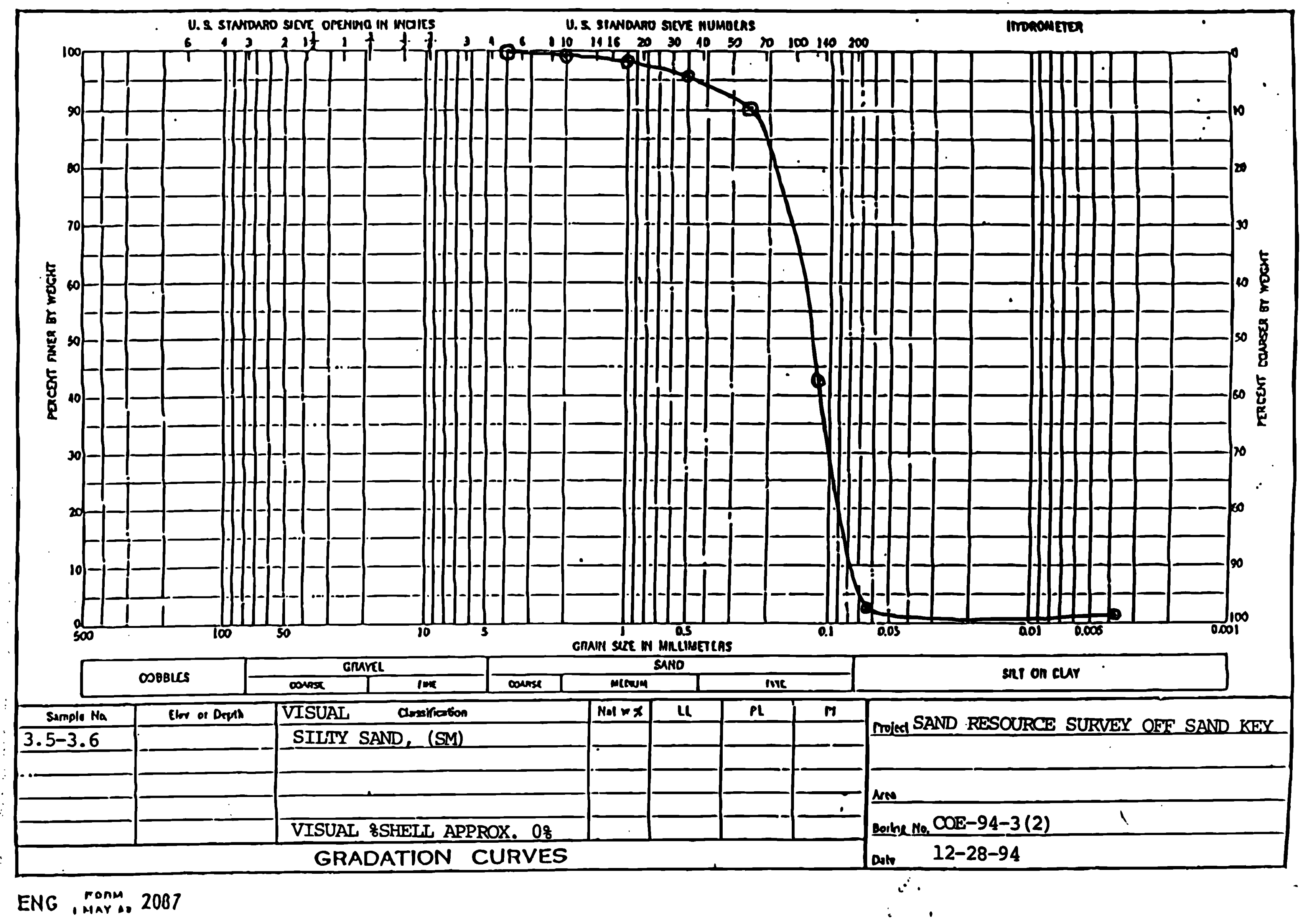




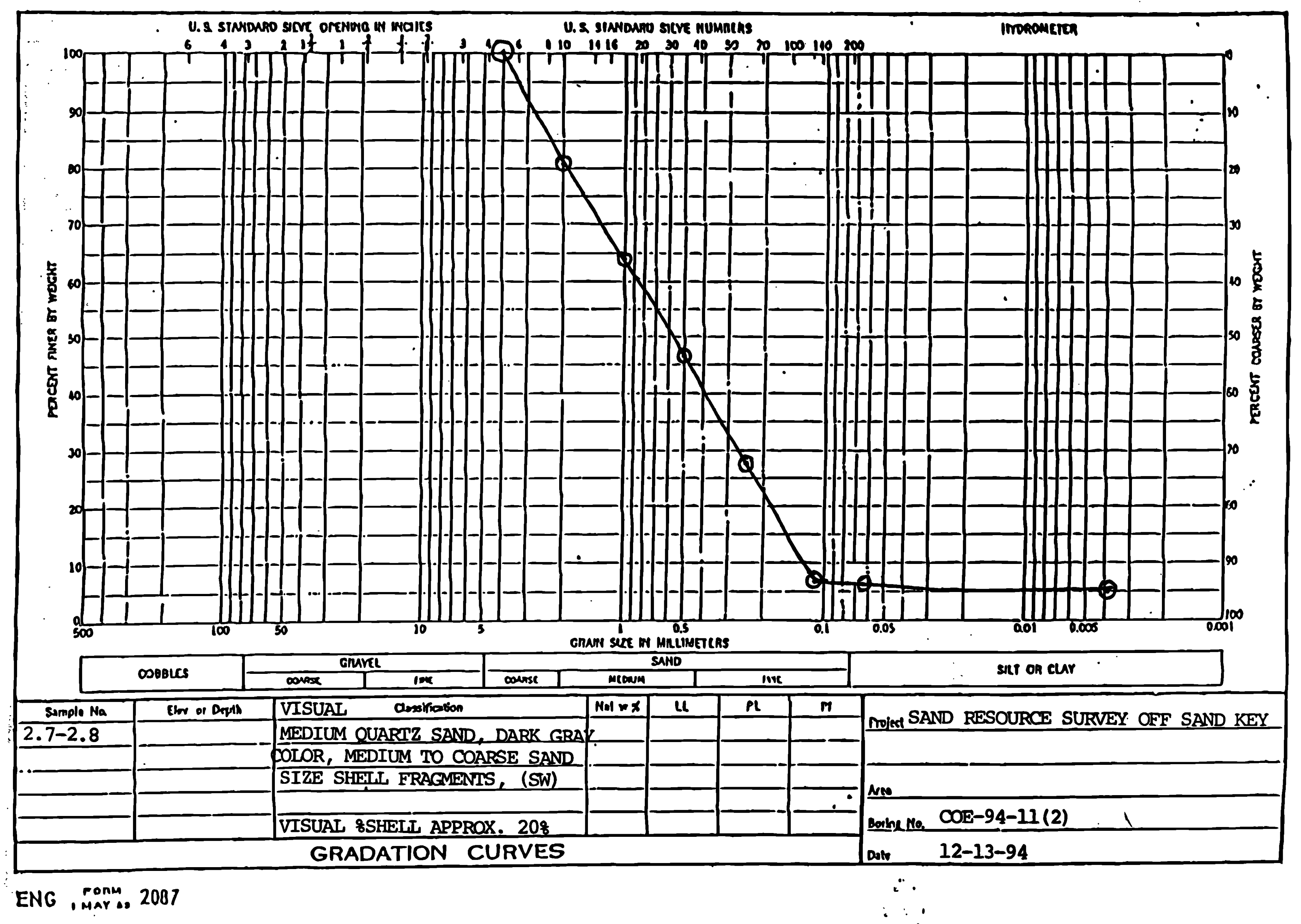




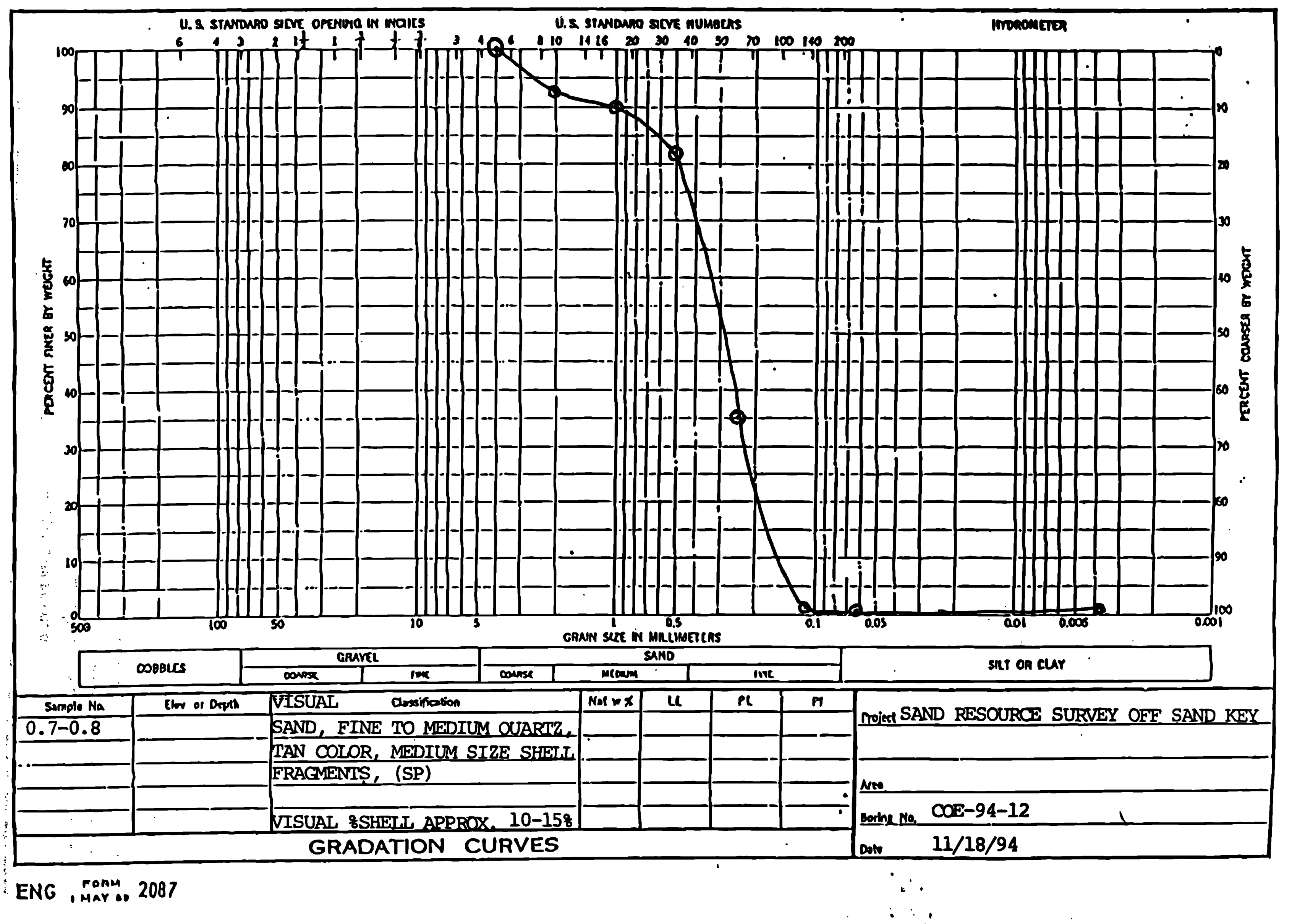




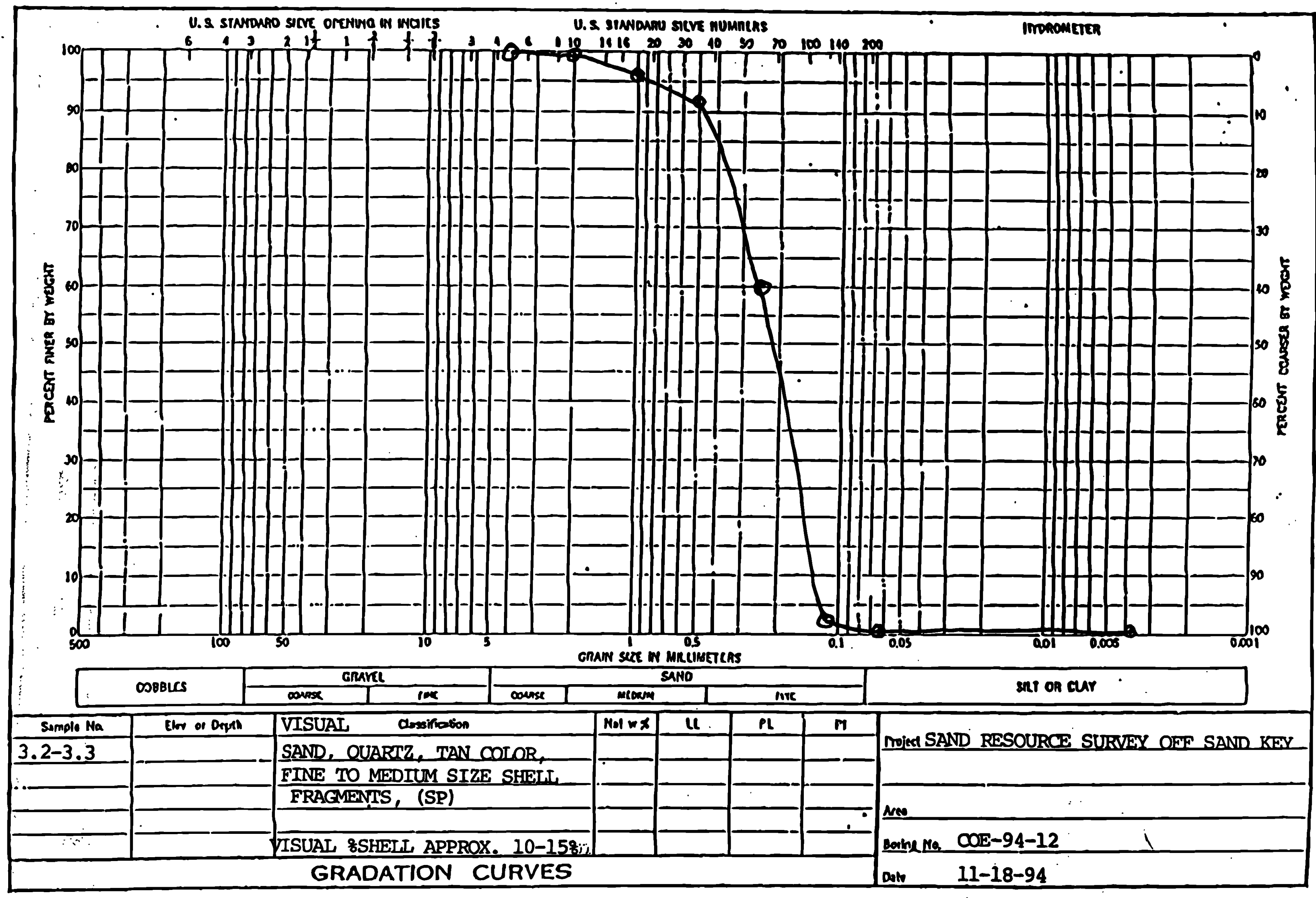

ENG , ronm 2087 


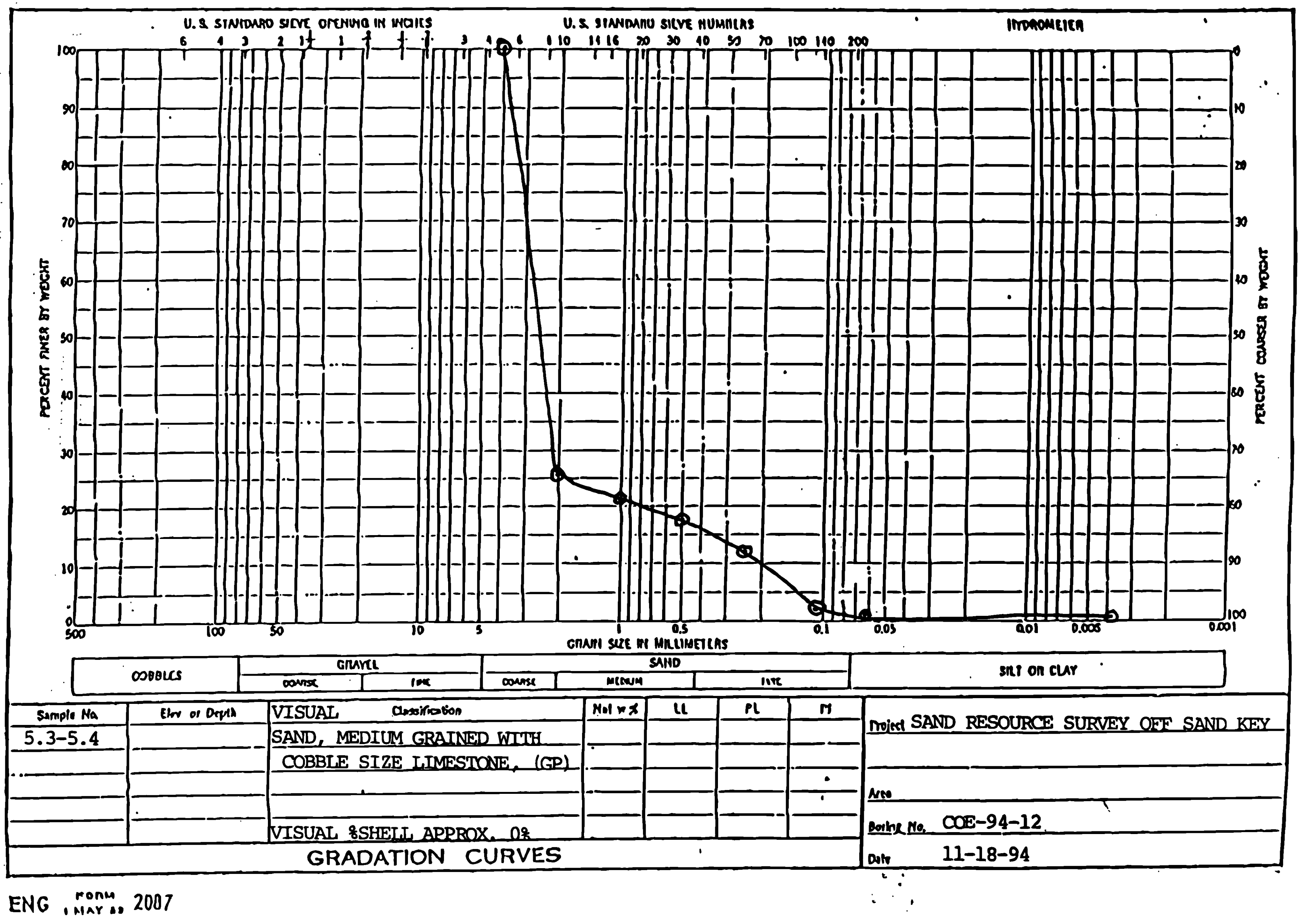




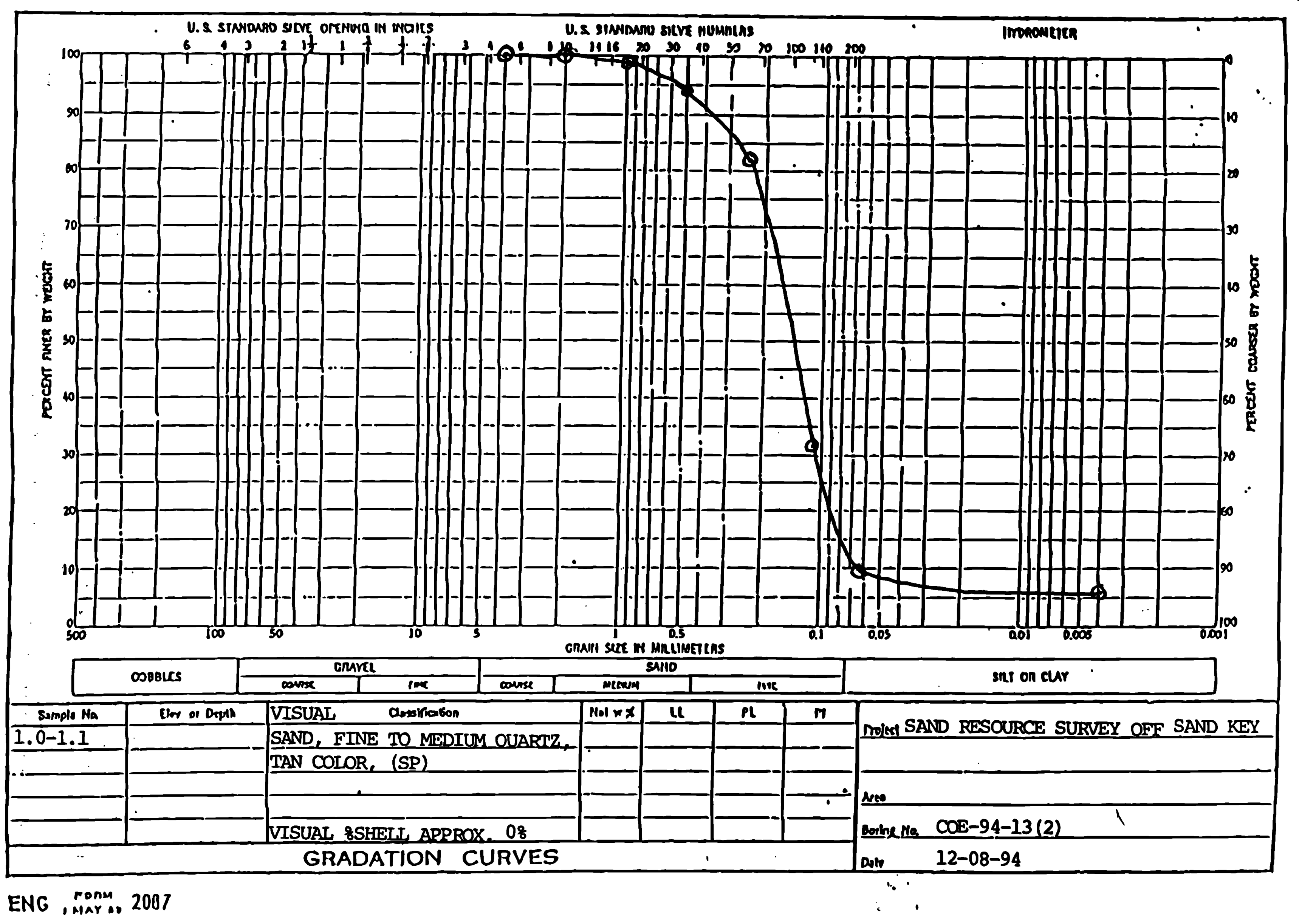




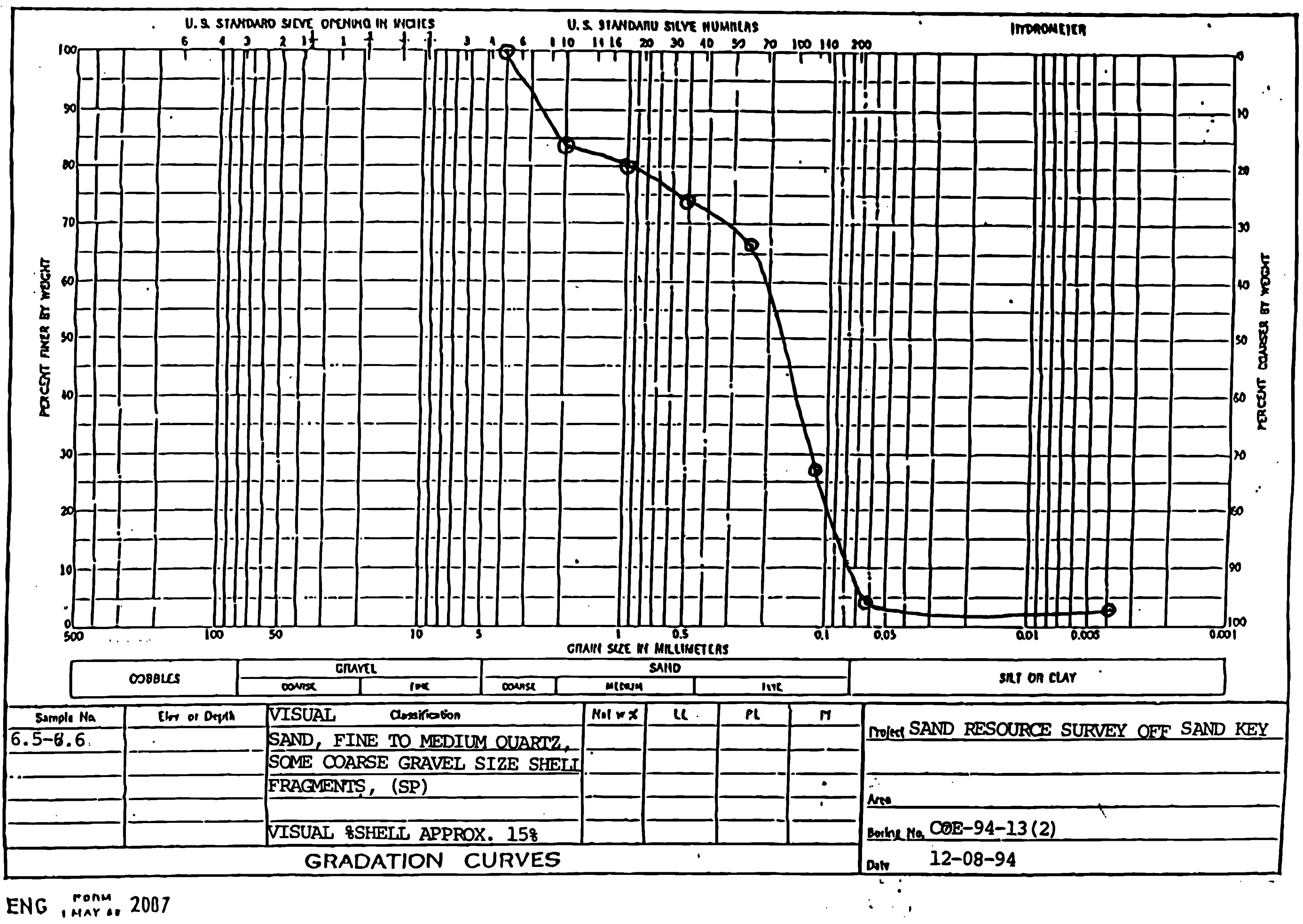




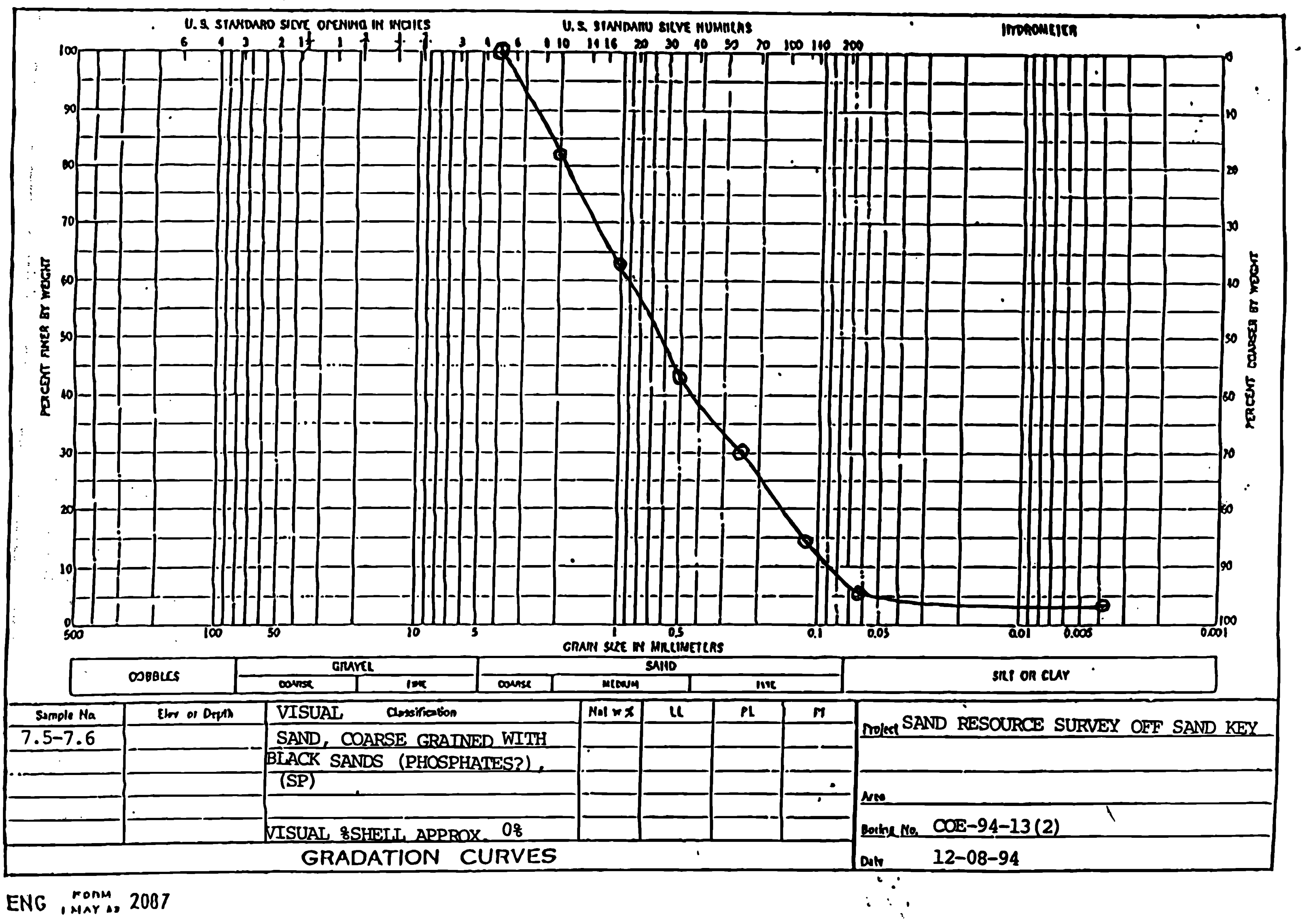




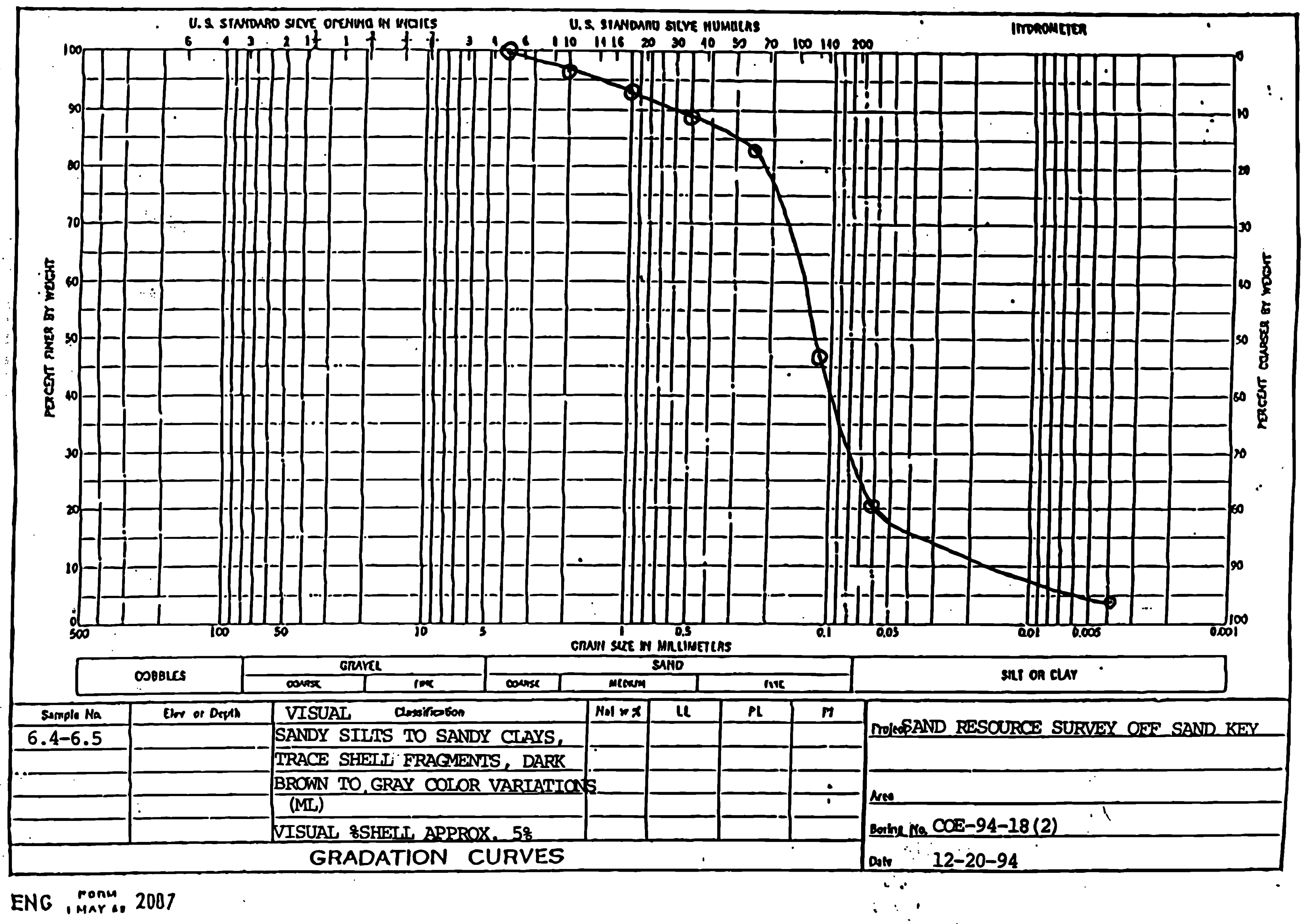




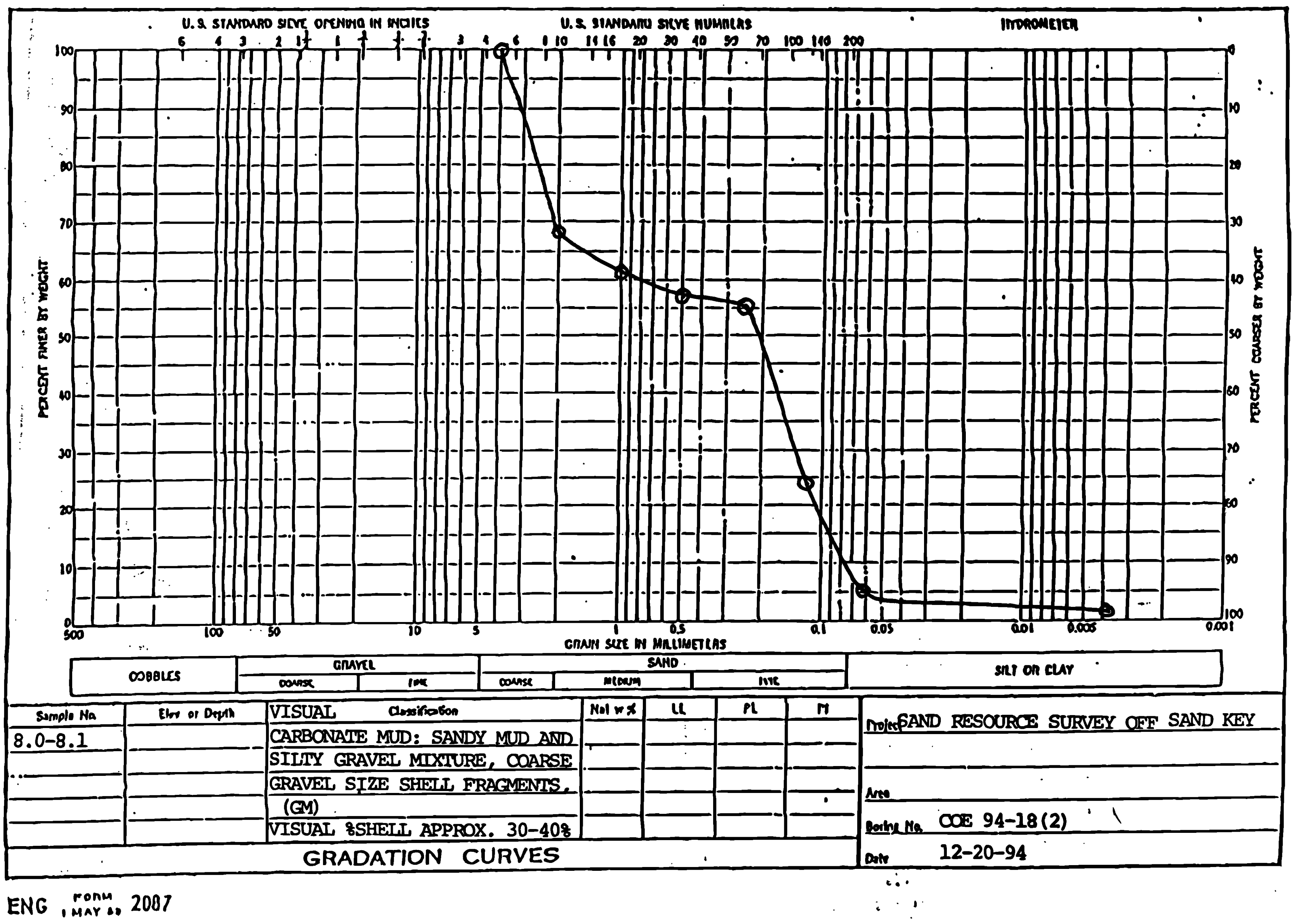




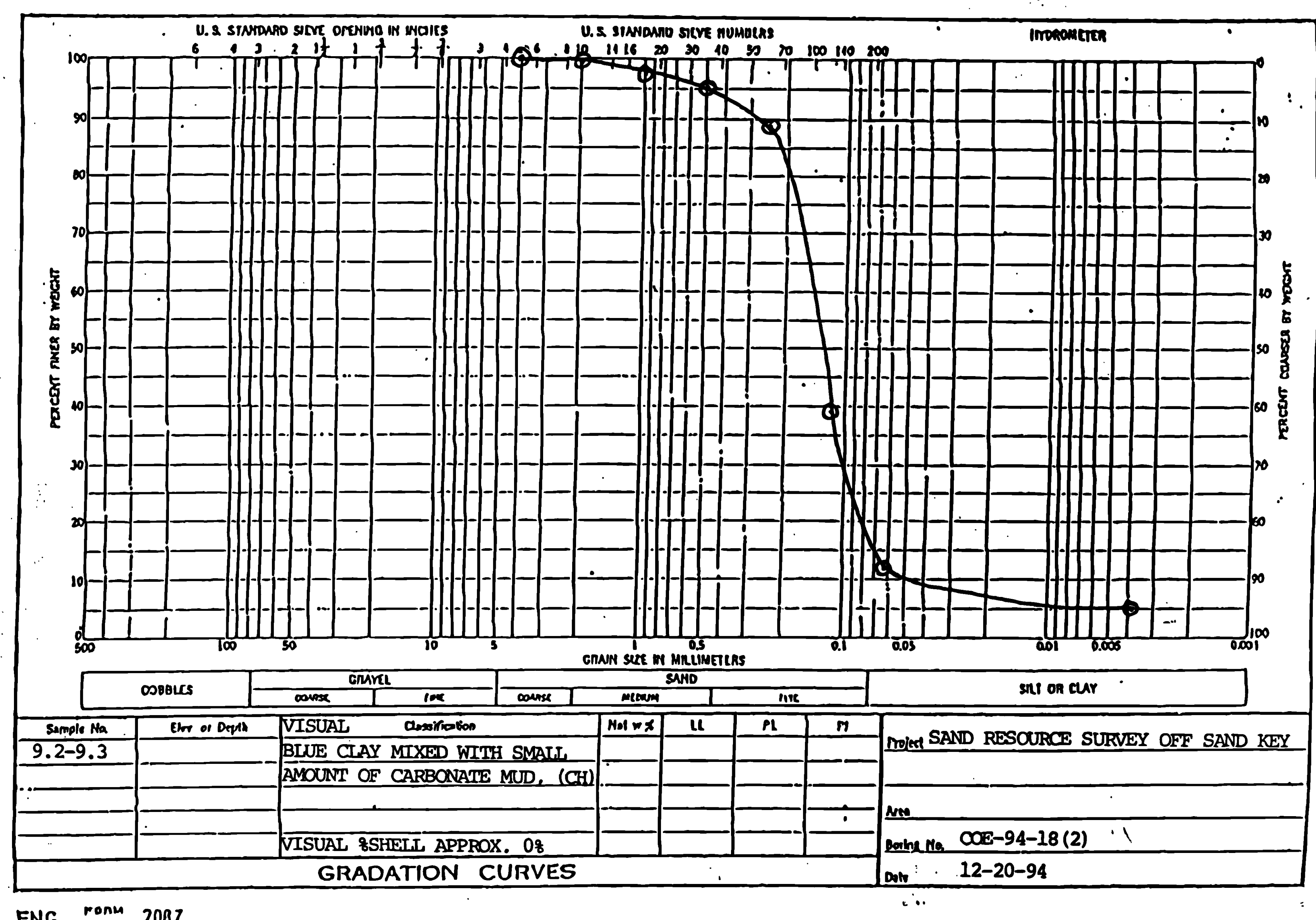




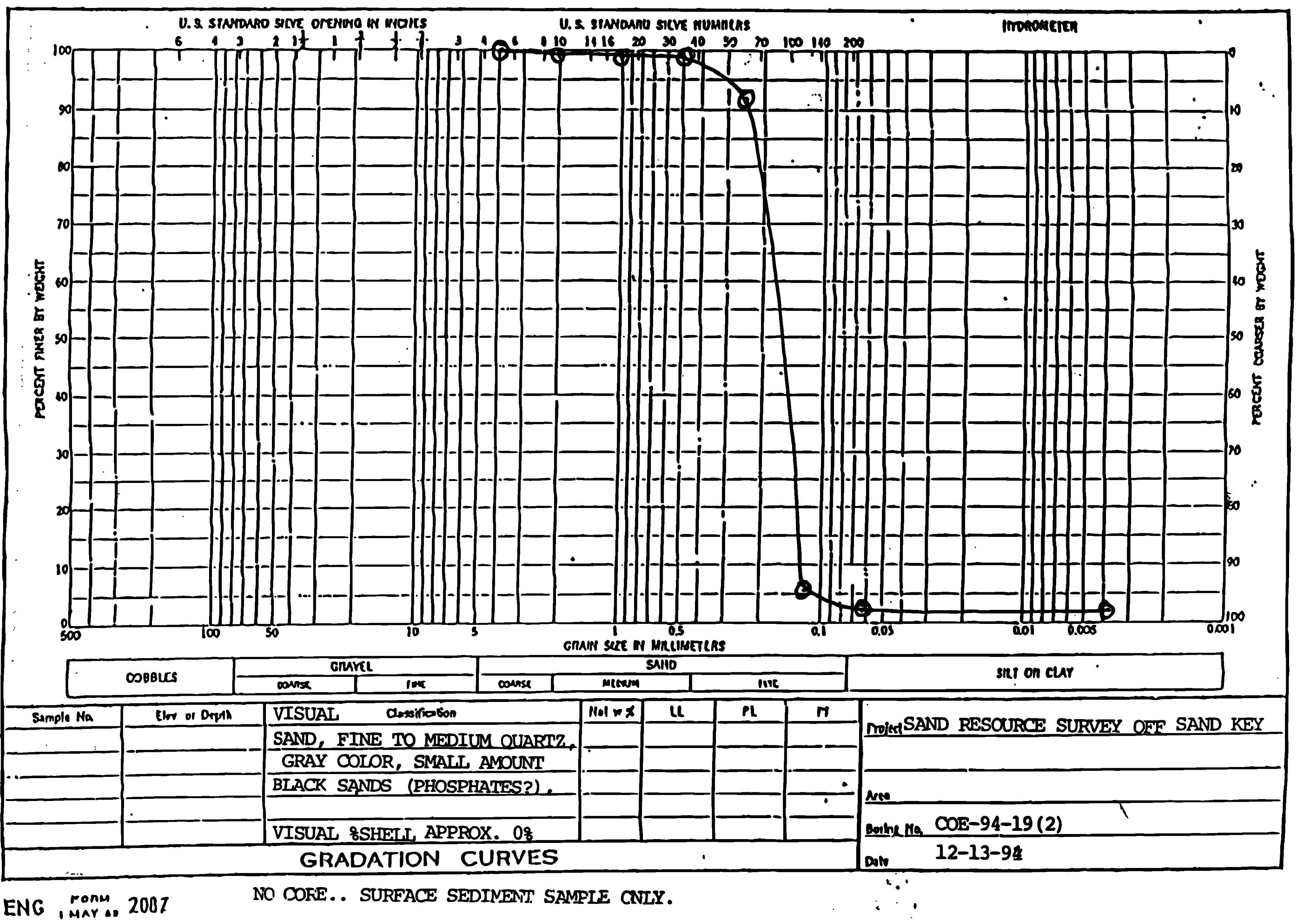




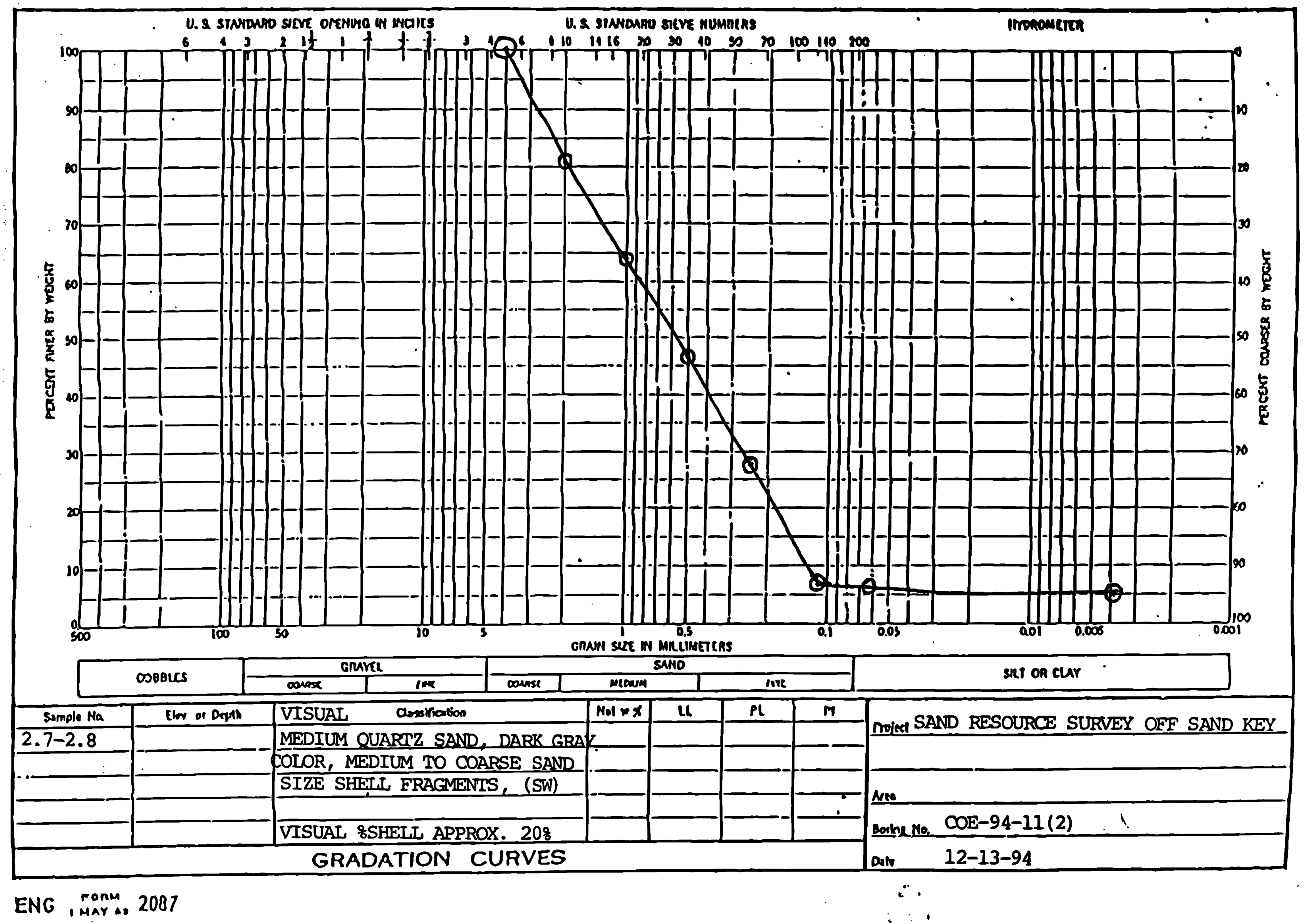




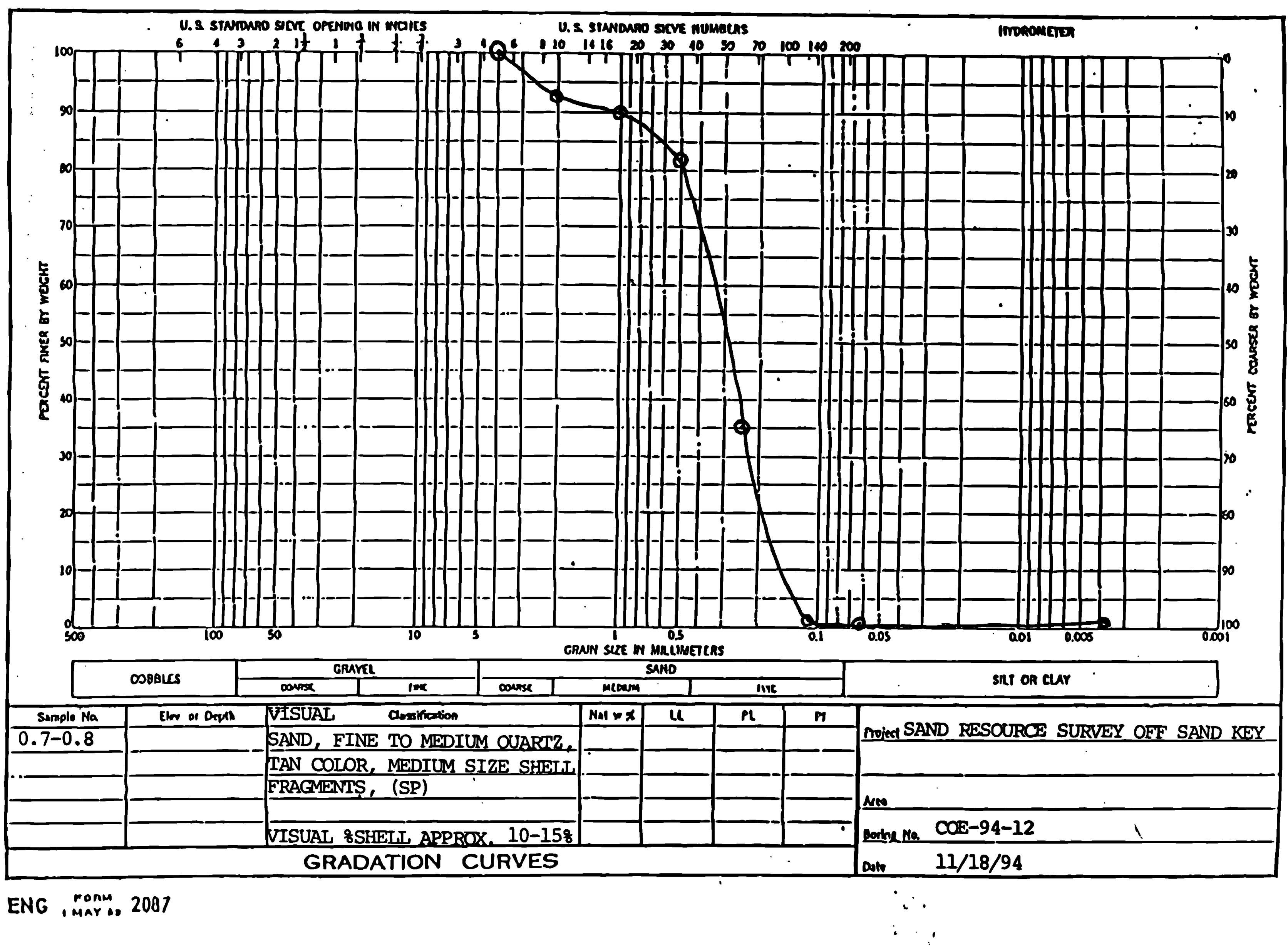




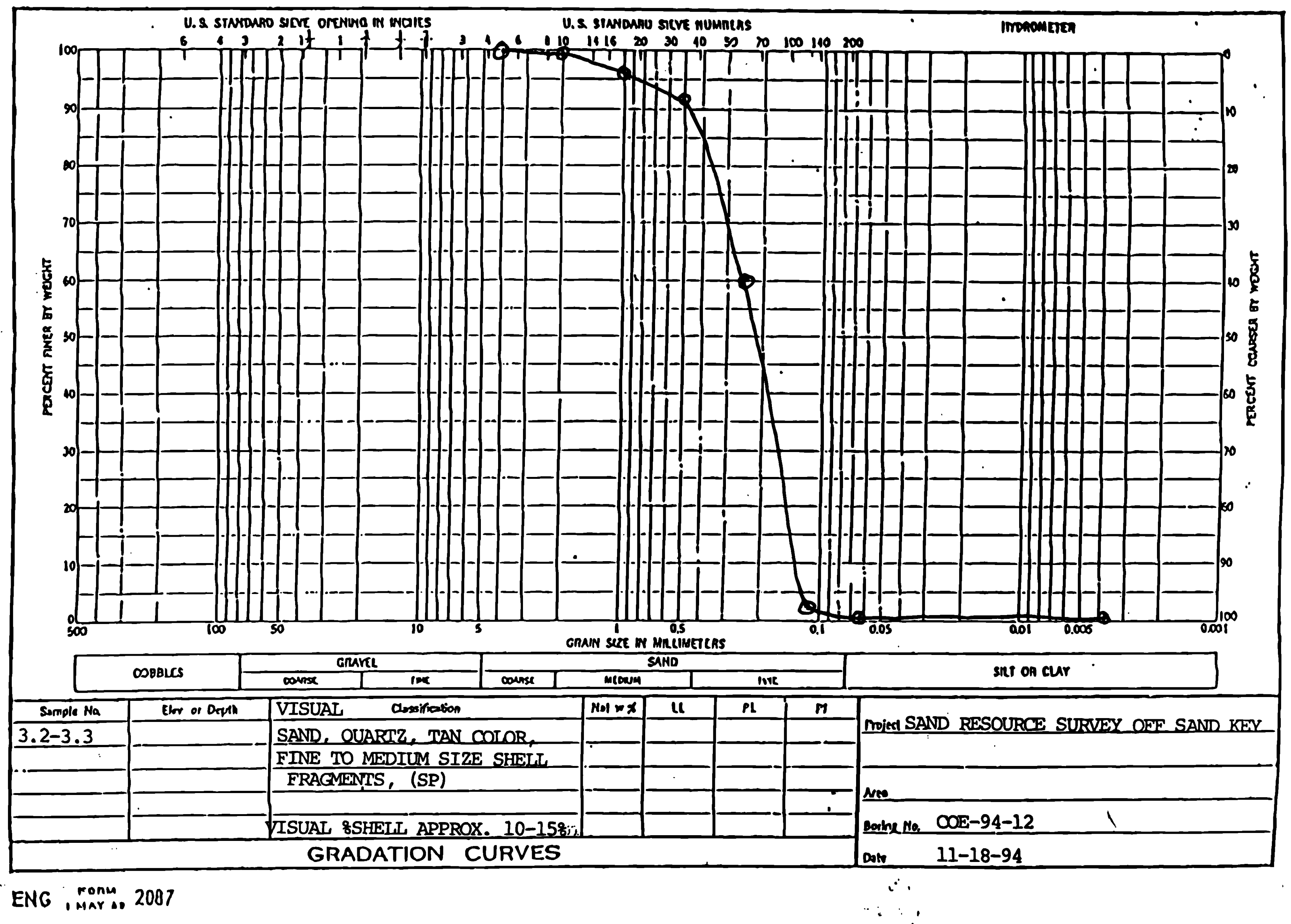




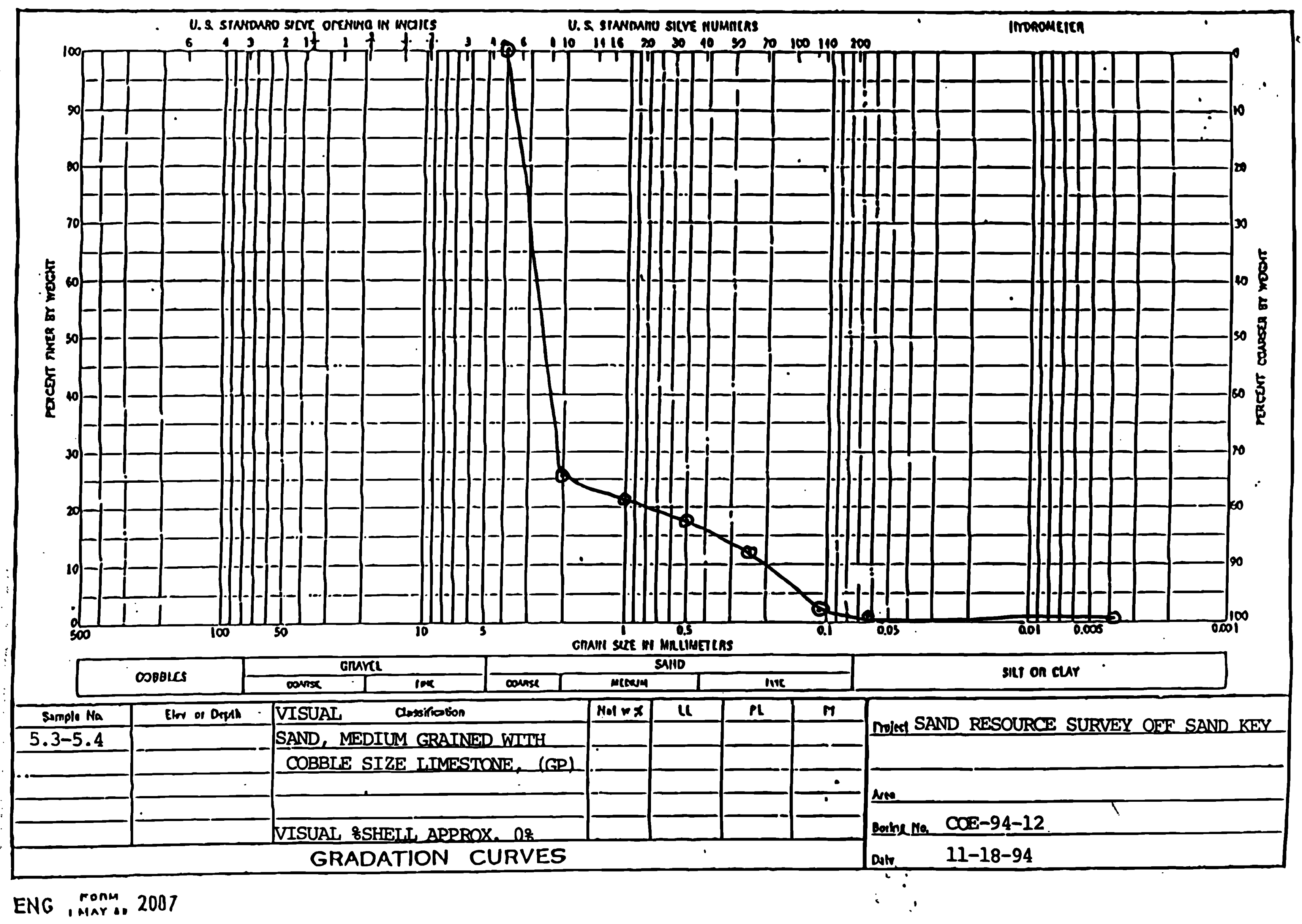




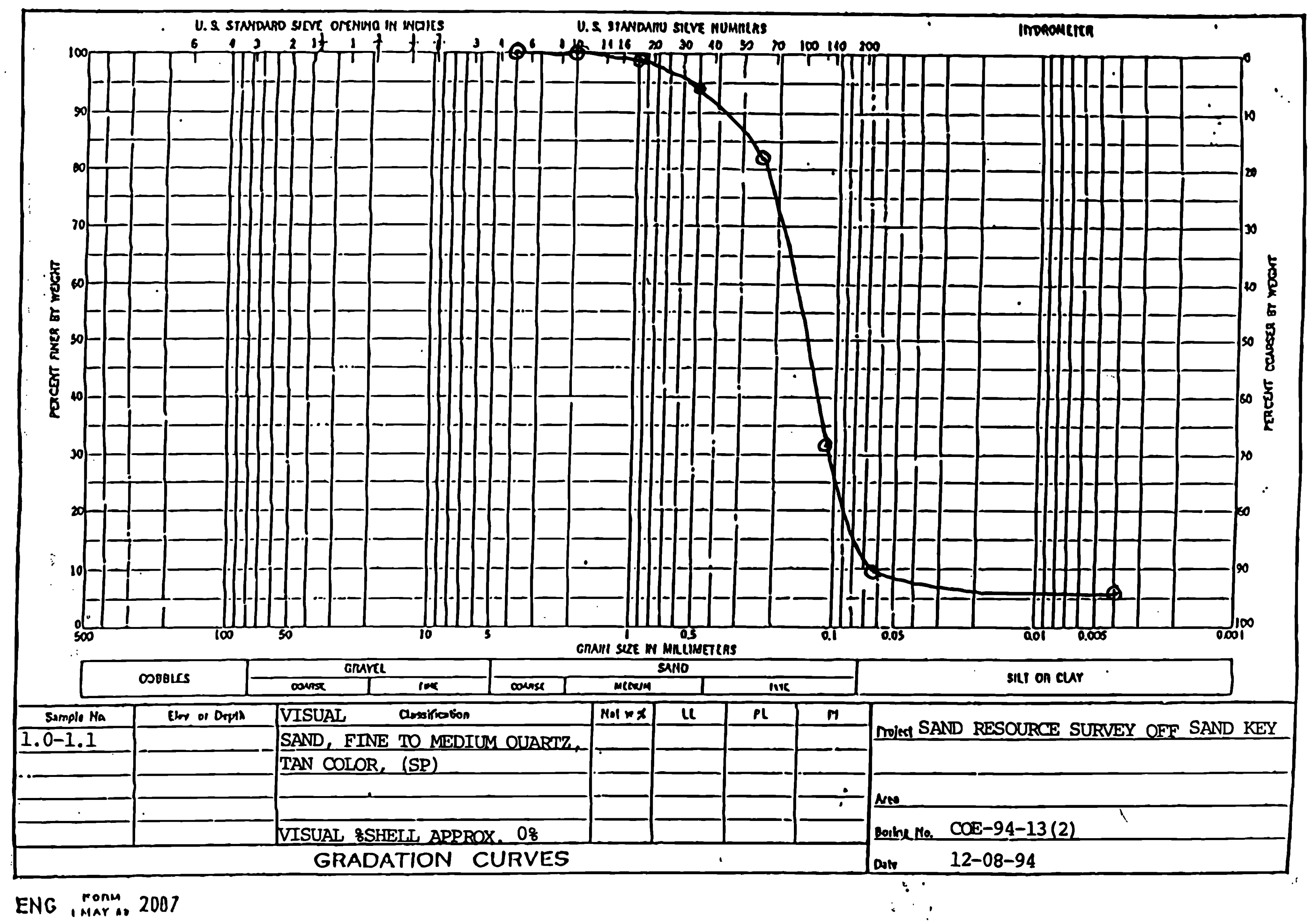




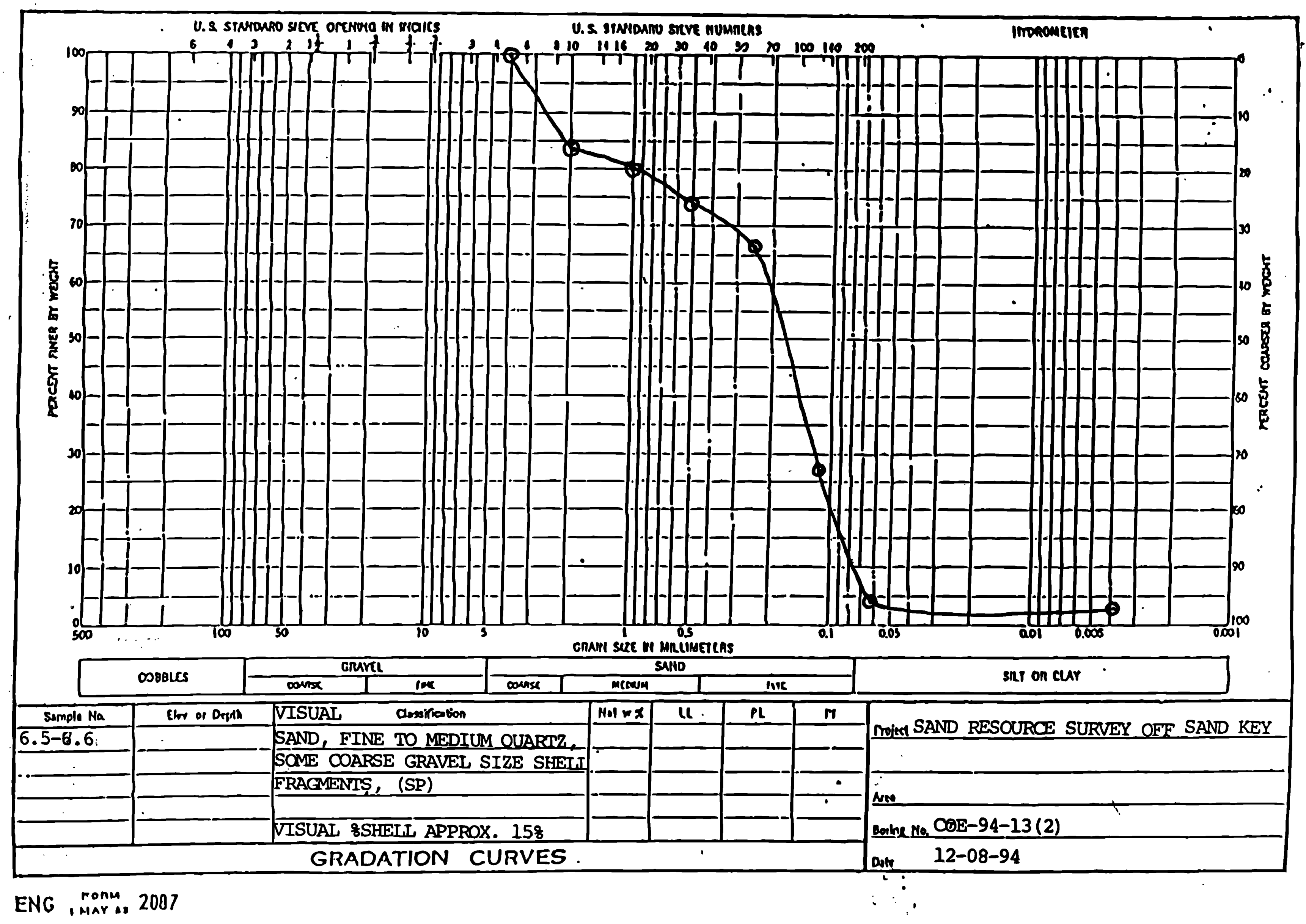




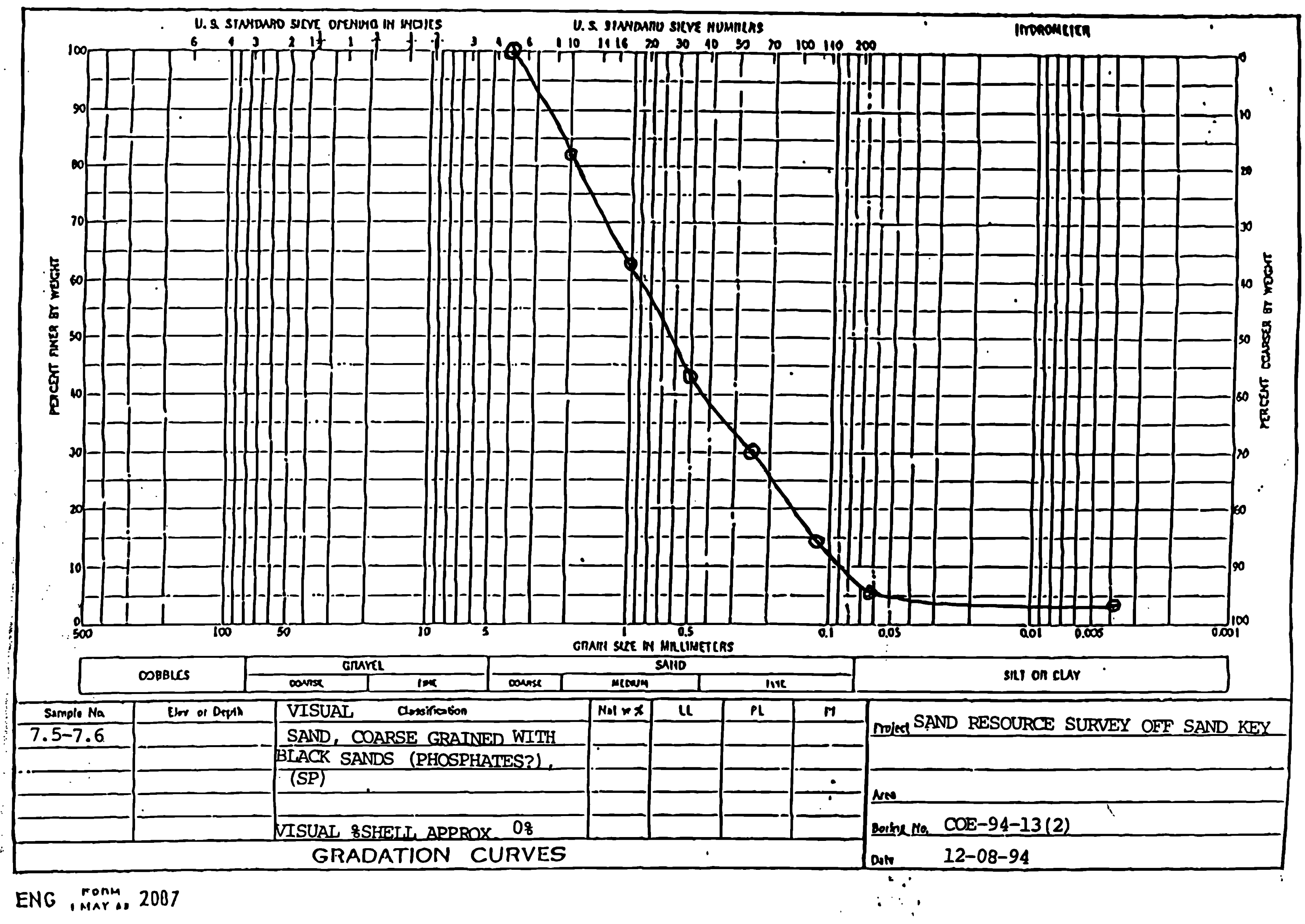




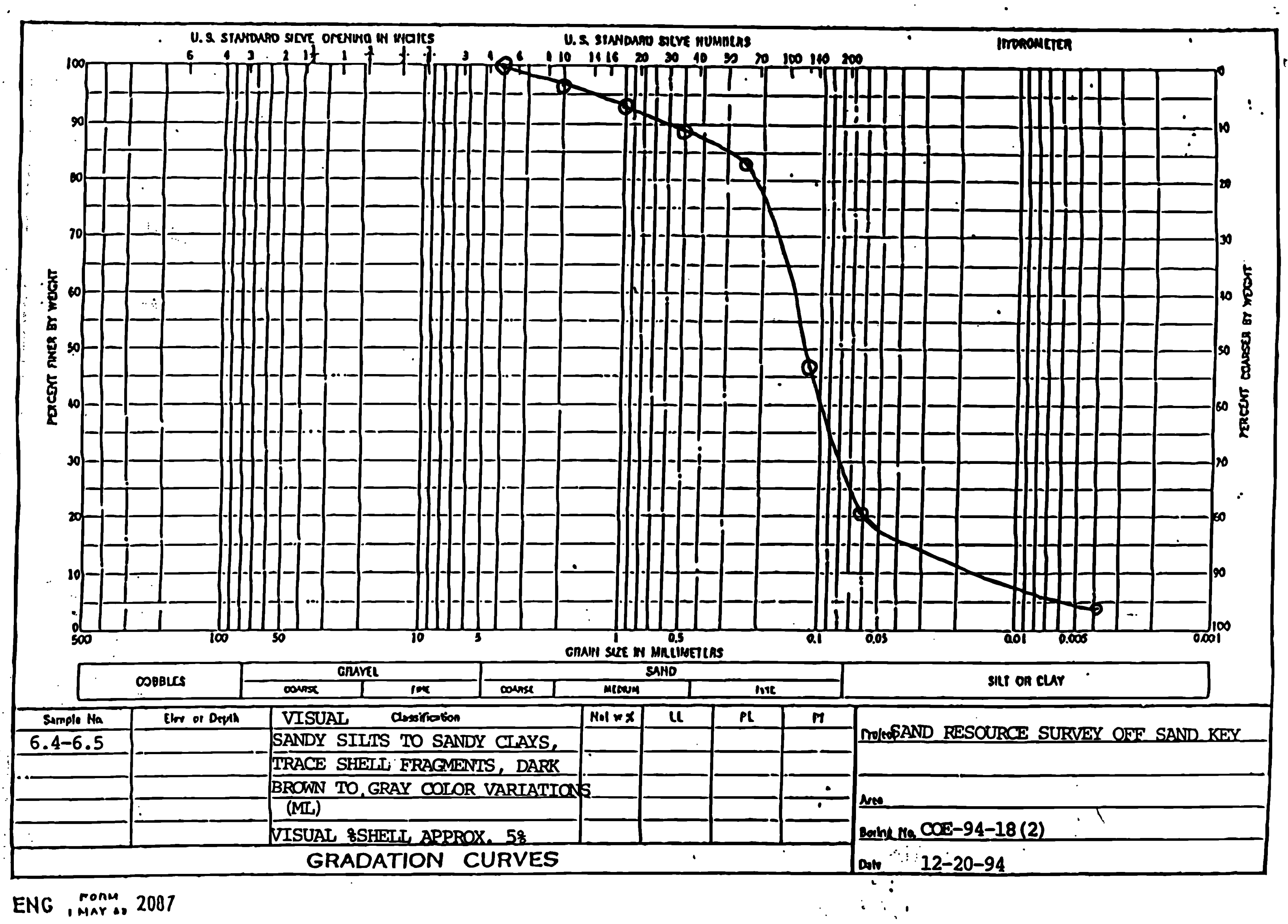




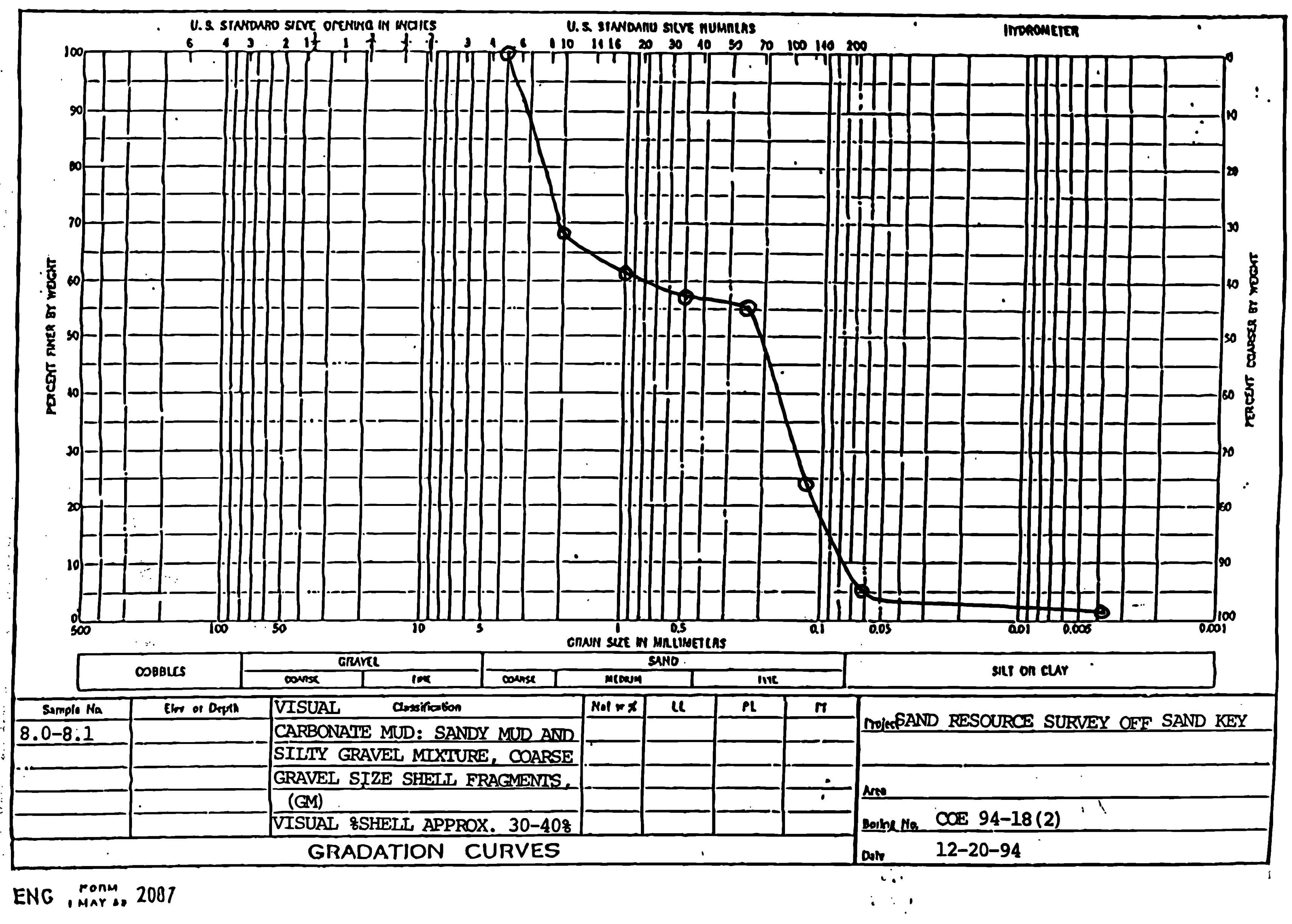




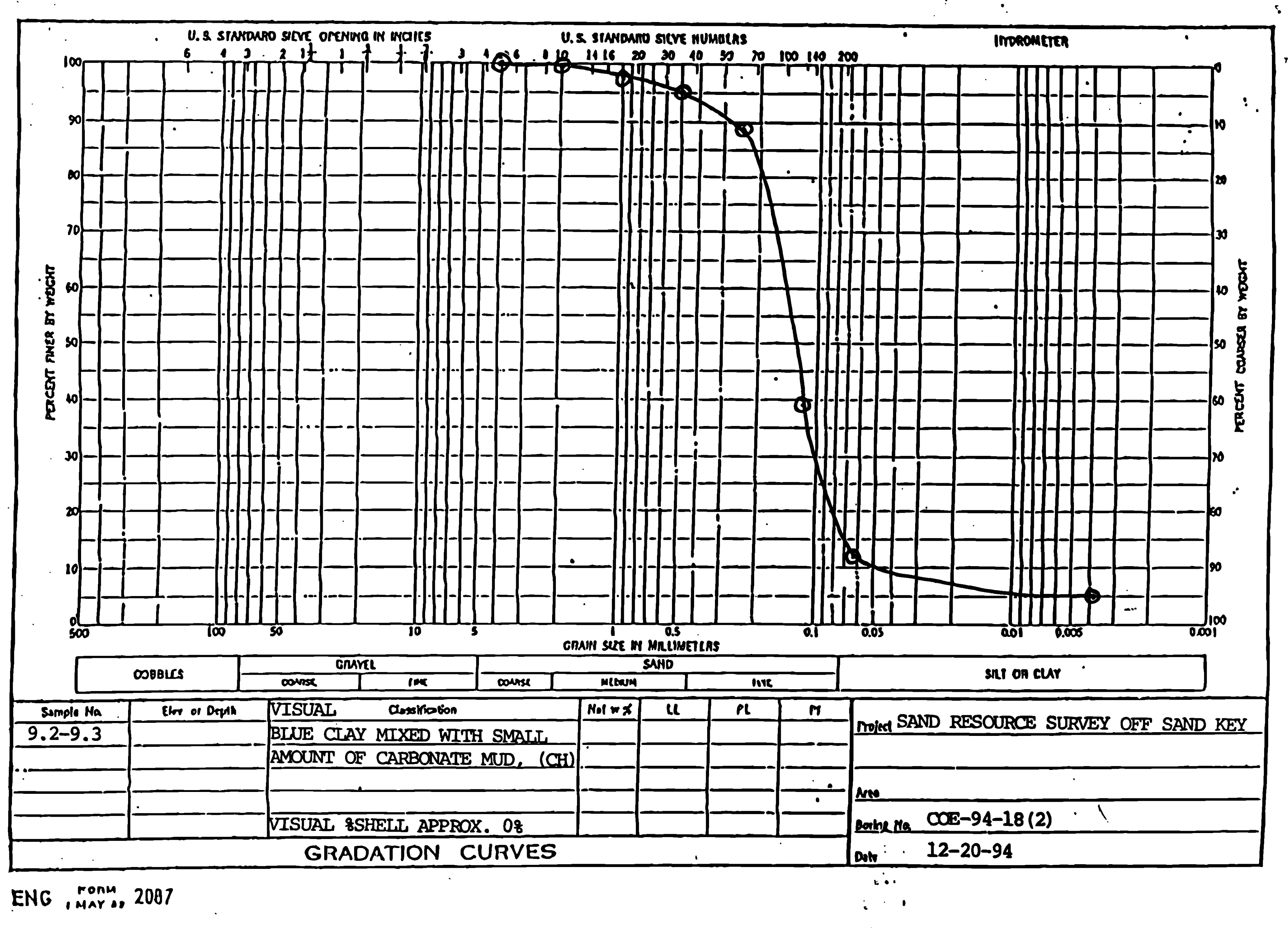




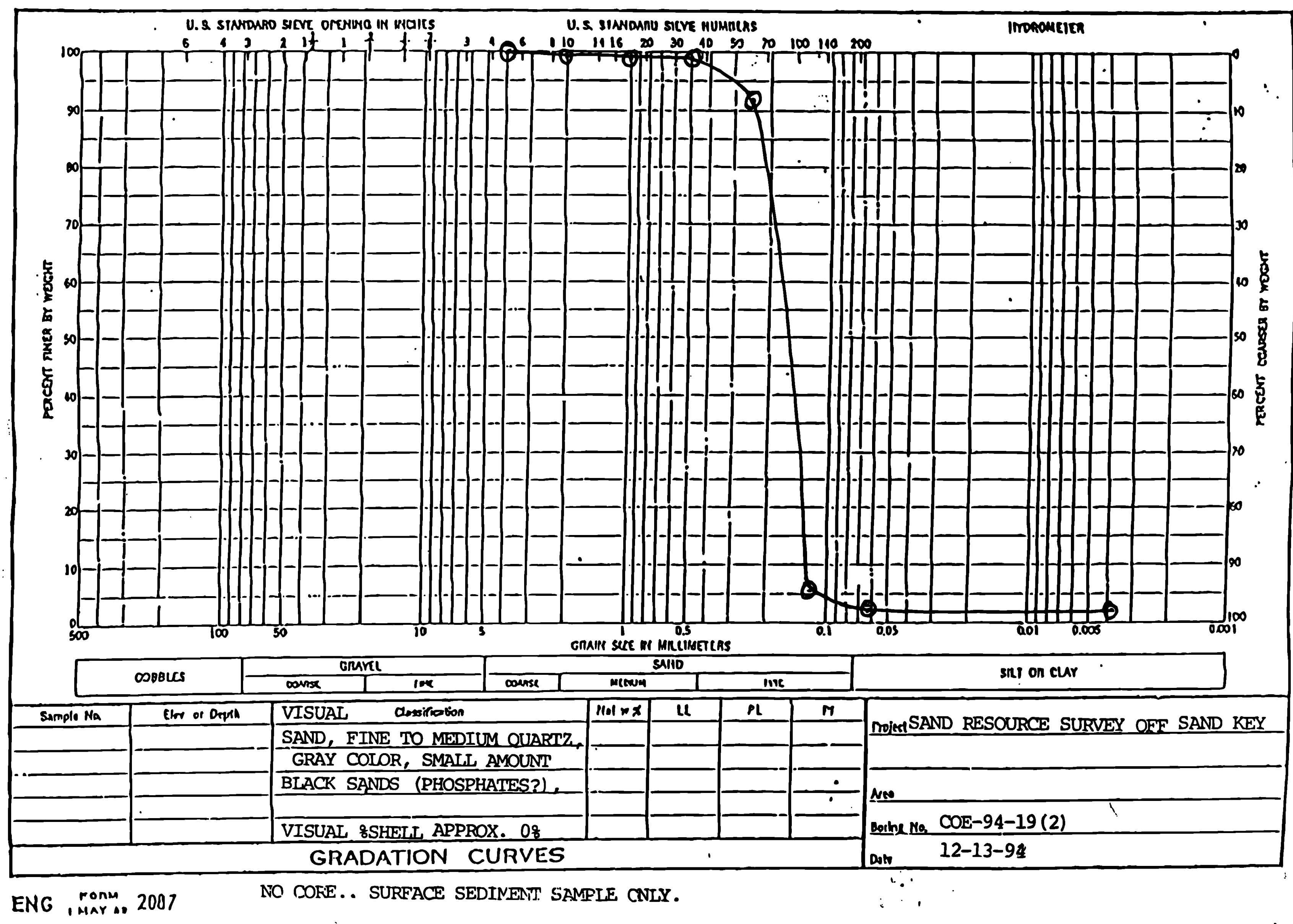




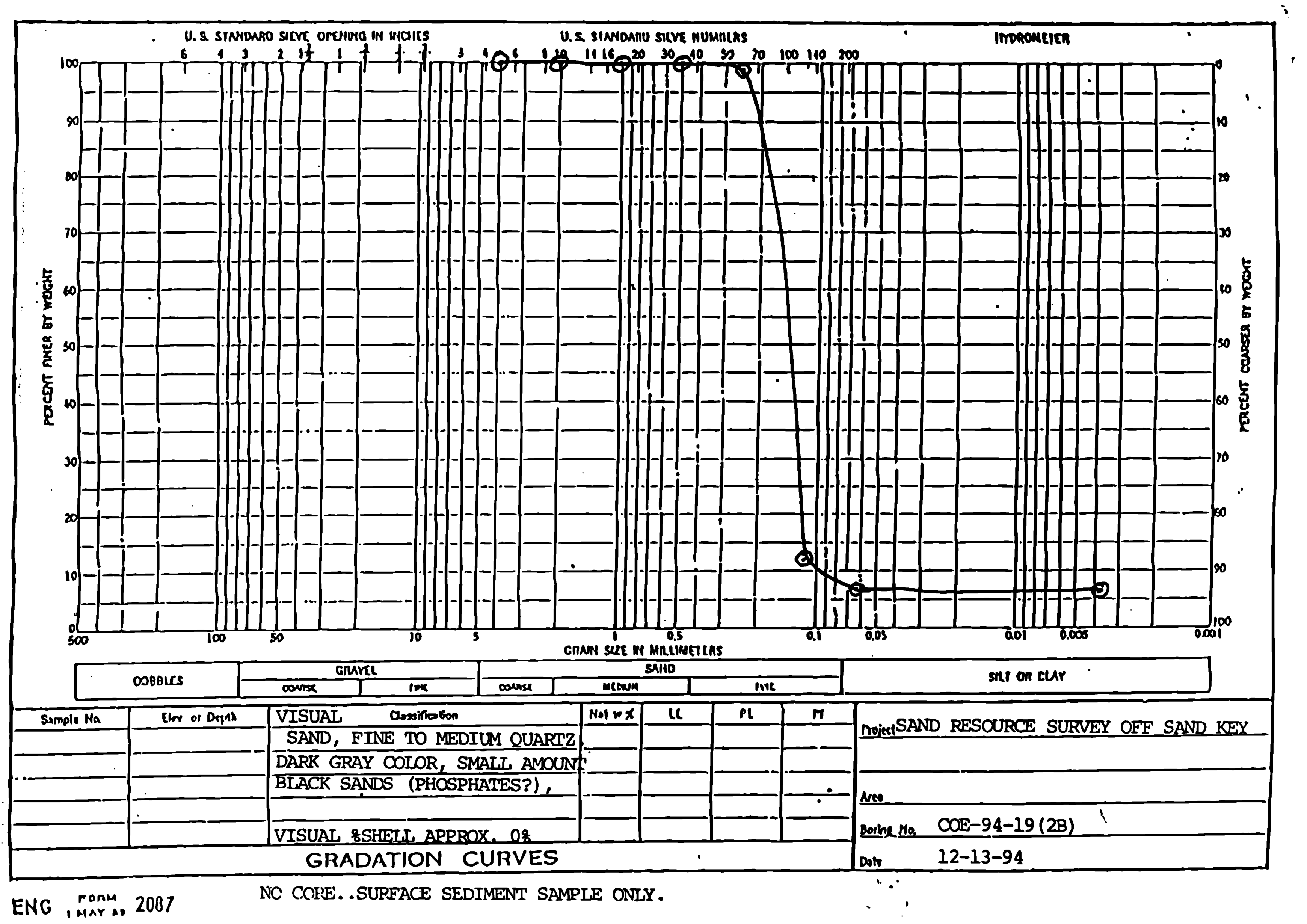




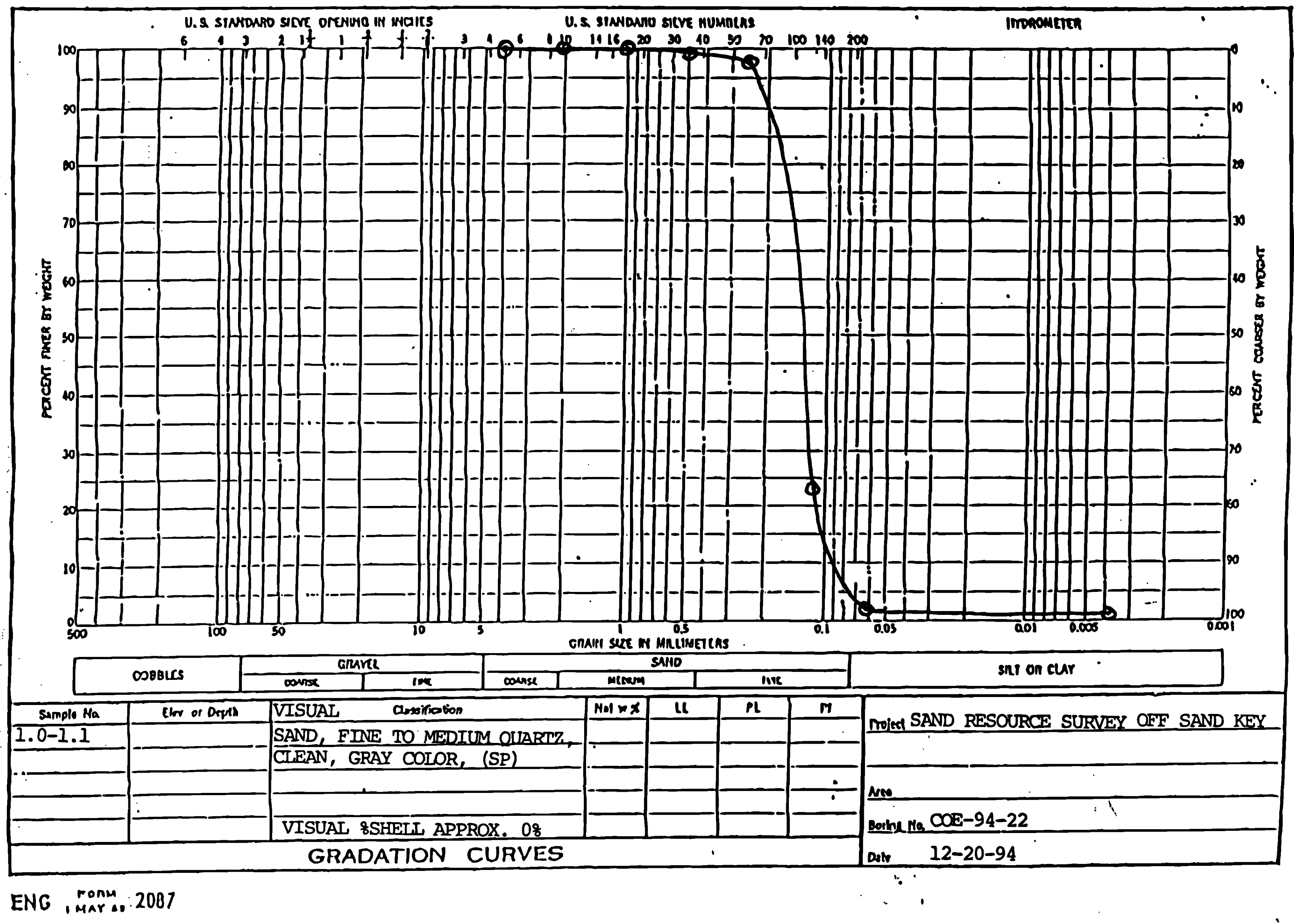




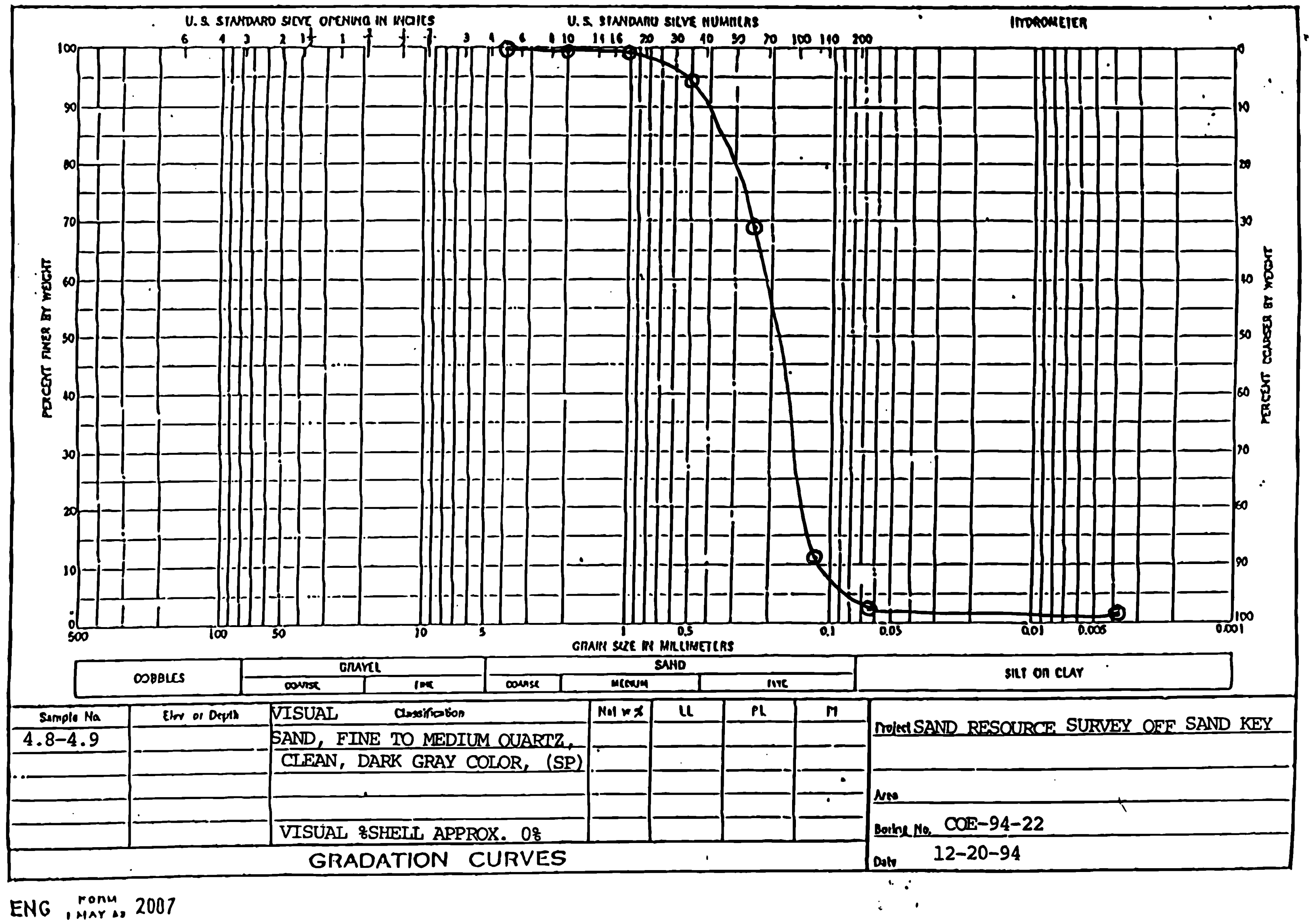




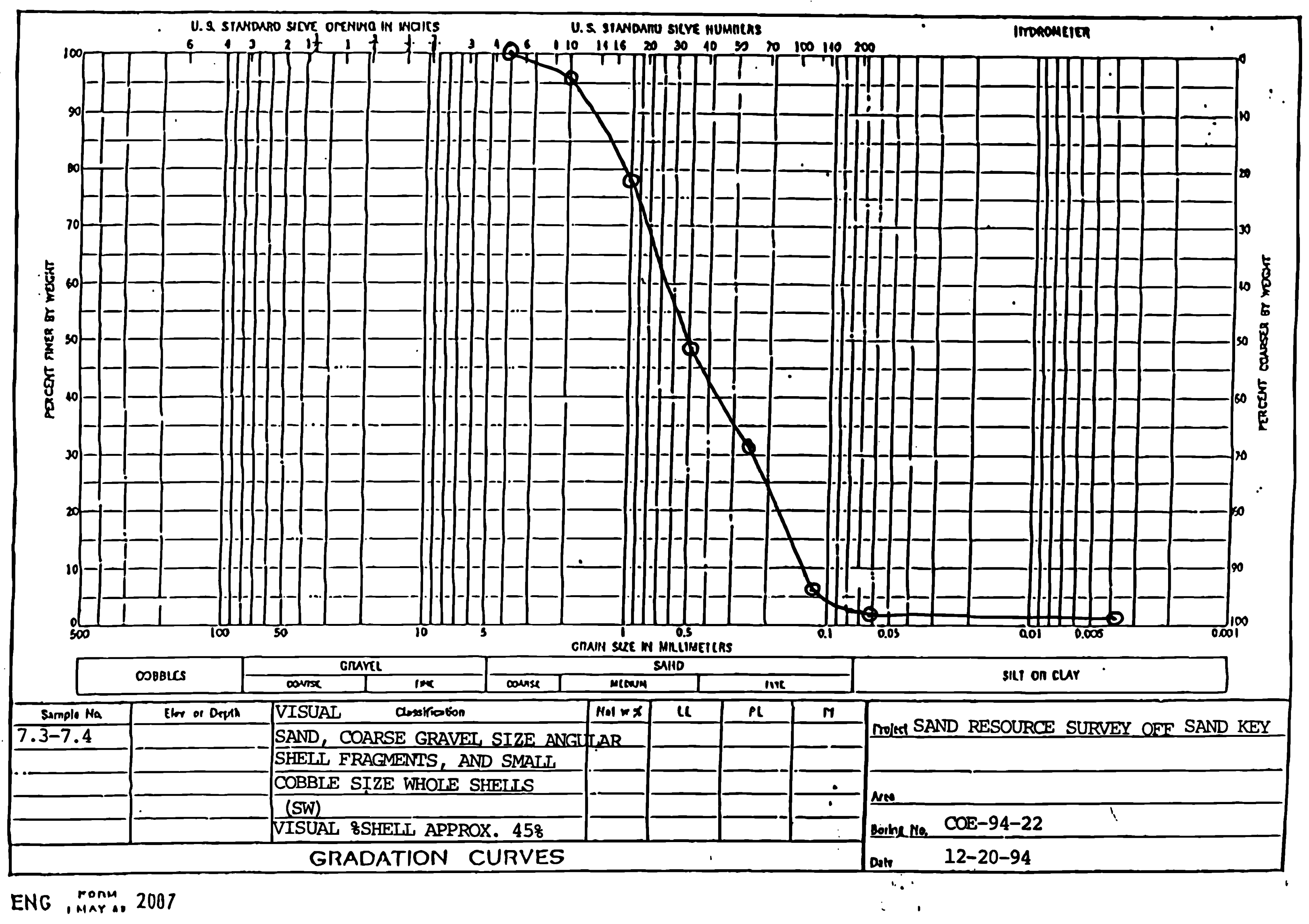




\section{Location Map}

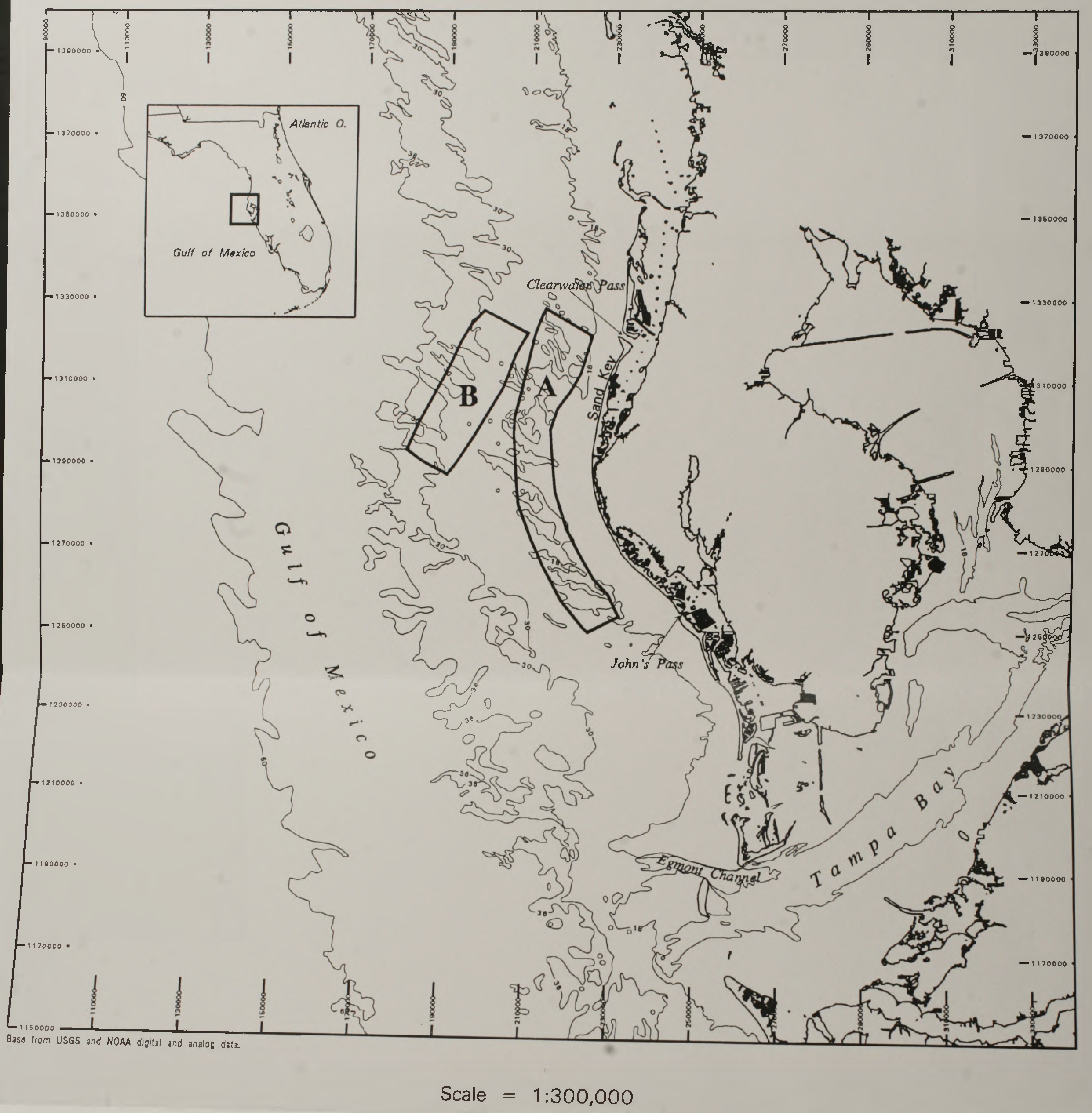

$5 \rightleftharpoons 10$

$5 \quad 5 \quad 1 \quad 10015$ KILOMETERS

Contours in feet

Vertical Datum: Mean lower low water

Horizontal Datum: NAD27

Transverse mercator

20,000 foot

(on Florida Coordinate System, West Zone 


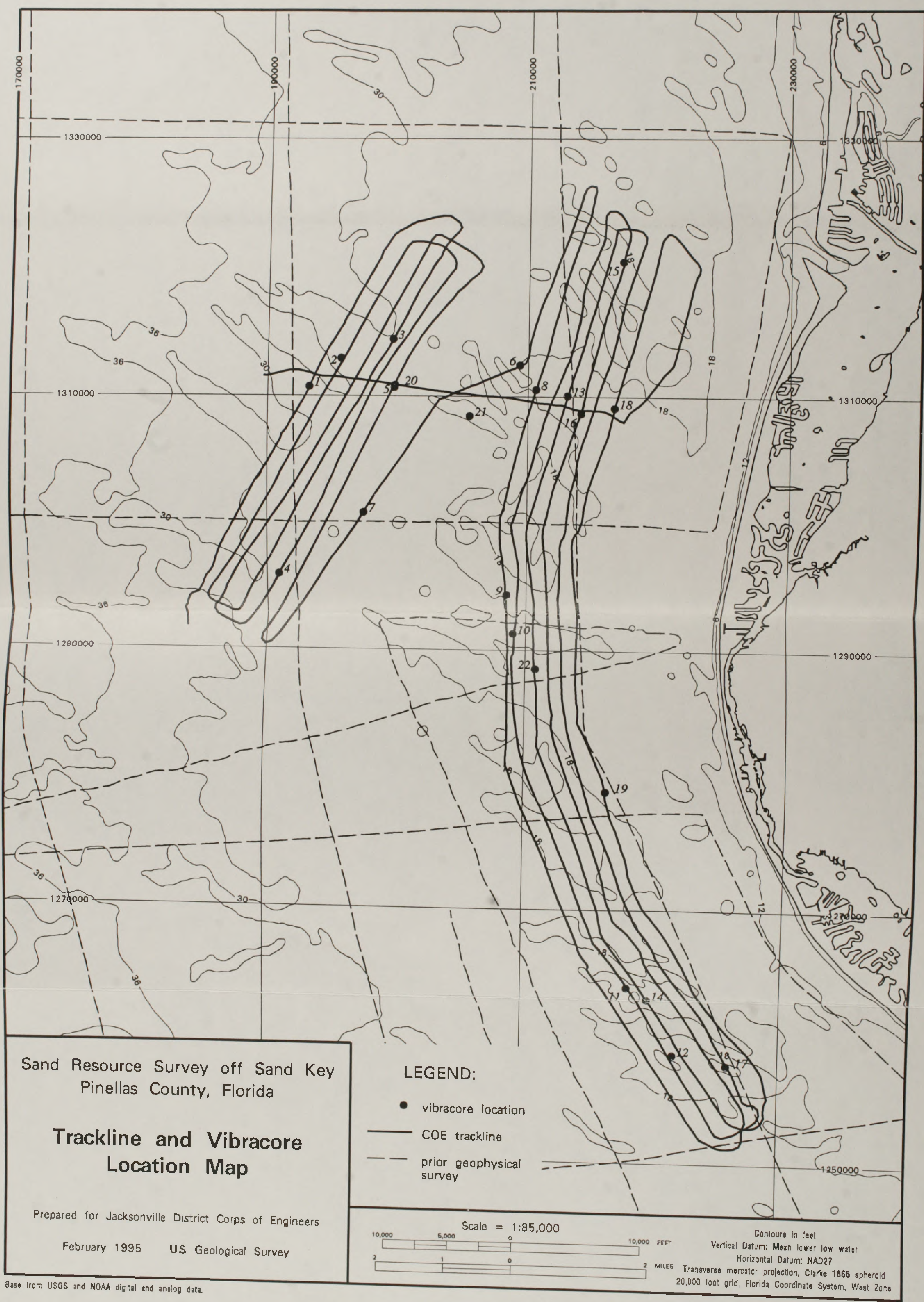

Plate 2 


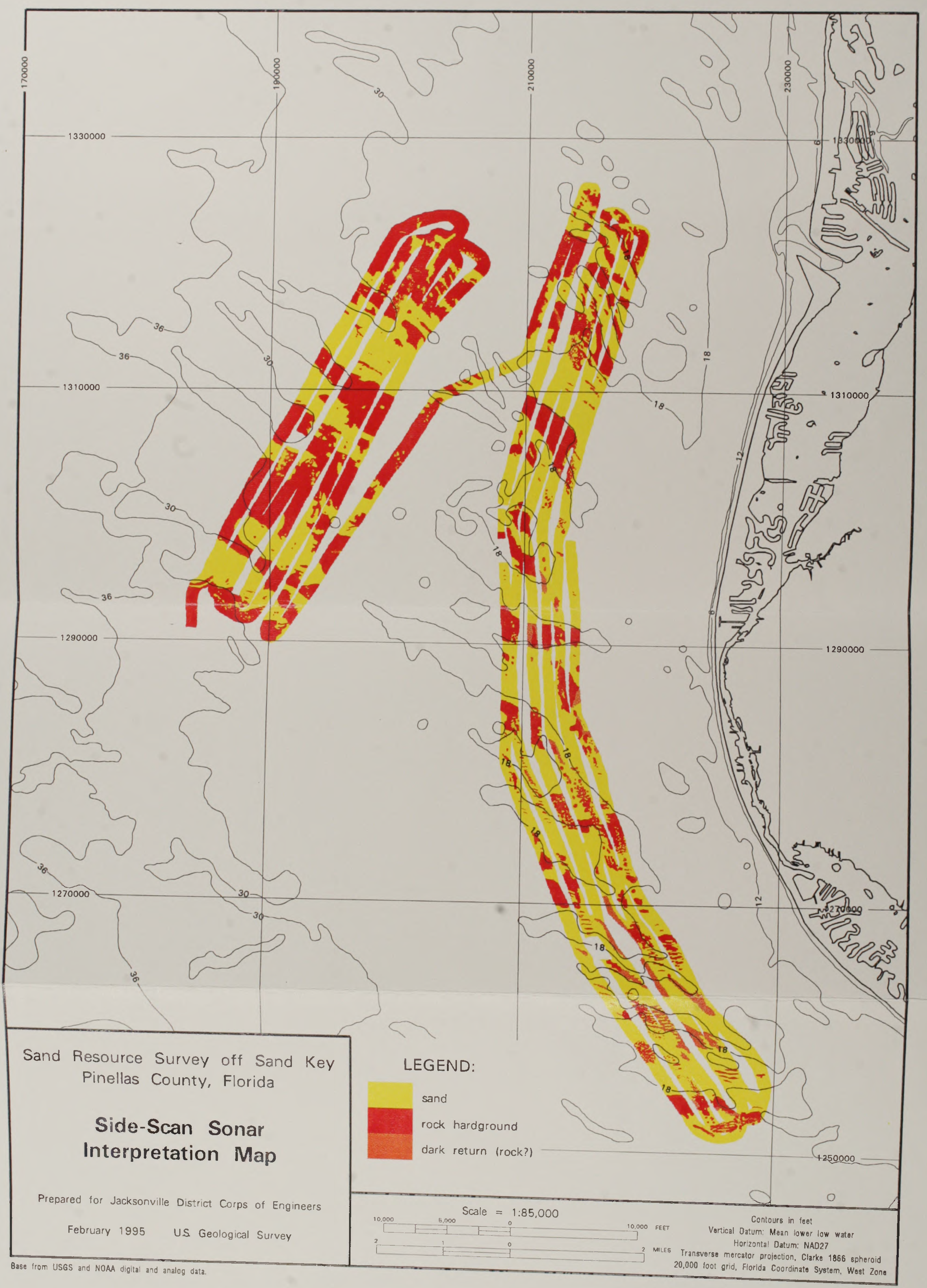


